Prepared in cooperation with the city of Wichita, Kansas

\title{
Status of Groundwater Levels and Storage Volume in the Equus Beds Aquifer near Wichita, Kansas, January 2006 to January 2010
}

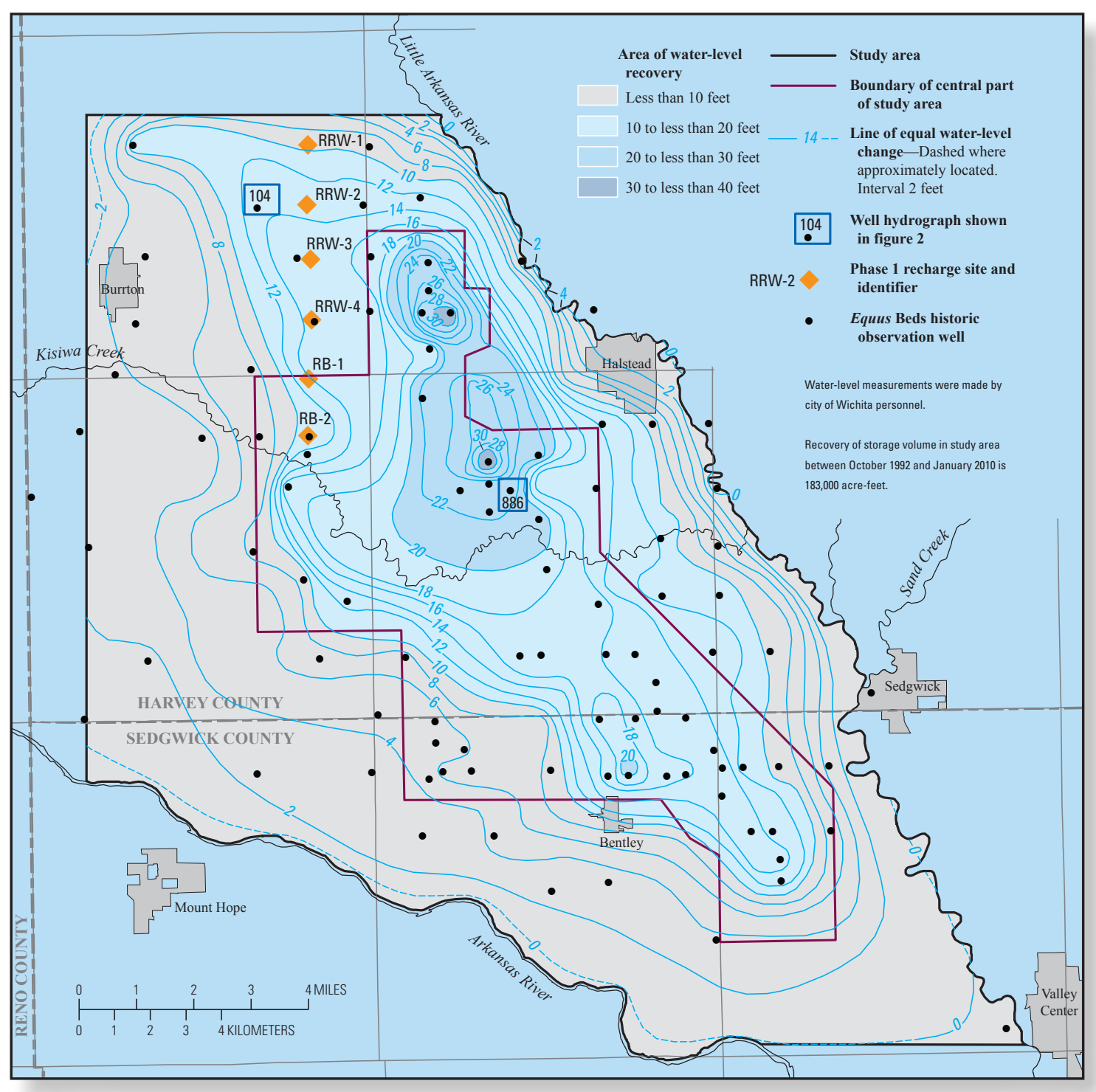

Scientific Investigations Report 2010-5231

U.S. Department of the Interior

U.S. Geological Survey 
Front cover: Map showing water-level changes in the Equus Beds aquifer in the study area, October 1992 to January 2010.

Back cover: Photograph showing Phase 1 Artificial Storage and Recovery surface-water treatment facility near Halstead, Kansas. Photograph from city of Wichita. 


\section{Status of Groundwater Levels and Storage Volume in the Equus Beds Aquifer near Wichita, Kansas, January 2006 to January 2010}

By Cristi V. Hansen and Walter R. Aucott

Prepared in cooperation with the city of Wichita, Kansas

Scientific Investigations Report 2010-5231 


\section{U.S. Department of the Interior \\ KEN SALAZAR, Secretary \\ U.S. Geological Survey \\ Marcia K. McNutt, Director}

\section{U.S. Geological Survey, Reston, Virginia: 2010}

For more information on the USGS - the Federal source for science about the Earth, its natural and living resources, natural hazards, and the environment, visit http://www.usgs.gov or call 1-888-ASK-USGS

For an overview of USGS information products, including maps, imagery, and publications, visit http://www.usgs.gov/pubprod

Any use of trade, product, or firm names is for descriptive purposes only and does not imply endorsement by the U.S. Government.

Although this report is in the public domain, permission must be secured from the individual copyright owners to reproduce any copyrighted materials contained within this report.

Suggested citation:

Hansen, C.V., and Aucott, W.R., 2010, Status of groundwater levels and storage volume in the Equus Beds aquifer near Wichita, Kansas, January 2006 to January 2010: U.S. Geological Survey Scientific Investigations Report 20105231, $47 \mathrm{p}$. 


\section{Contents}

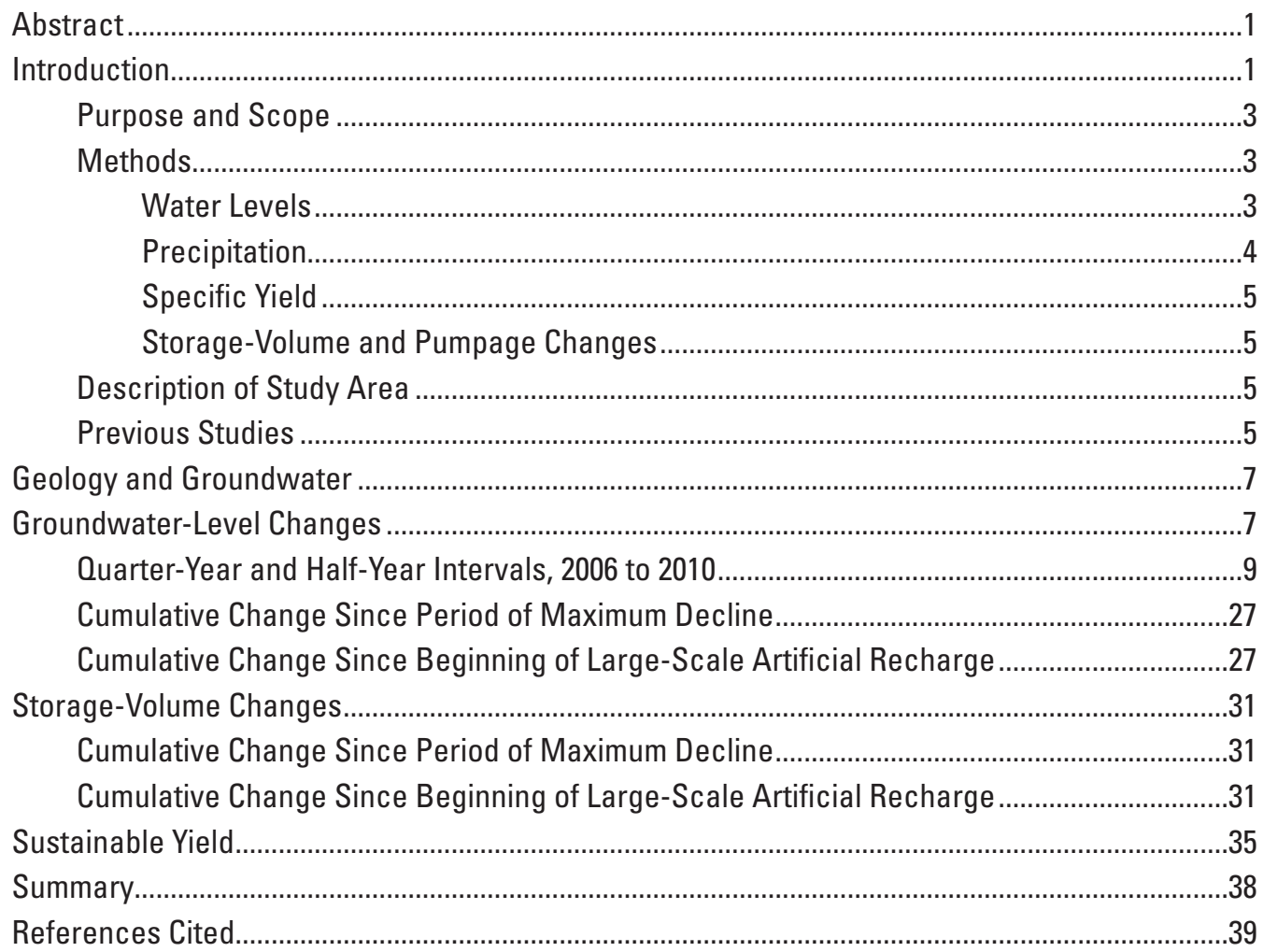

\section{Figures}

1. Map showing location of study area near Wichita, south-central Kansas

2. Graph showing relation of $(A)$ precipitation, $(B)$ water use for agricultural irrigation and by city of Wichita for public supply, and $(C)$ water-level altitudes in observation wells 104 and 886 and Equus Beds aquifer storage-volume change in study area 1938 to January 2010 ..................................................................

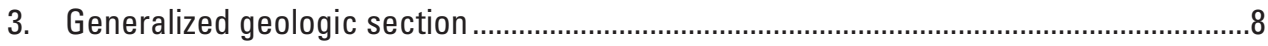

4. Map showing water-level altitudes in the Equus Beds aquifer in the study area, August 1940

5. Map showing water-level altitudes in the Equus Beds aquifer in the study area, October 1992

6. Map showing water-level altitudes in the Equus Beds aquifer in the study area, January 2010

7. Map showing water-level changes in the Equus Beds aquifer in the study area, August 1940 to January 2006

8. Map showing water-level changes in the Equus Beds aquifer in the study area, August 1940 to April 2006. 
9. Map showing water-level changes in the Equus Beds aquifer in the study area, August 1940 to July 2006

10. Map showing water-level changes in the Equus Beds aquifer in the study area, August 1940 to October 2006

11. Map showing water-level changes in the Equus Beds aquifer in the study area, August 1940 to January 2007

12. Map showing water-level changes in the Equus Beds aquifer in the study area, August 1940 to April 2007

13. Map showing water-level changes in the Equus Beds aquifer in the study area, August 1940 to July 2007

14. Map showing water-level changes in the Equus Beds aquifer in the study area, August 1940 to October 2007

15. Map showing water-level changes in the Equus Beds aquifer in the study area, August 1940 to January 2008

16. Map showing water-level changes in the Equus Beds aquifer in the study area, August 1940 to April 2008

17. Map showing water-level changes in the Equus Beds aquifer in the study area, August 1940 to July 2008

18. Map showing water-level changes in the Equus Beds aquifer in the study area, August 1940 to January 2009.

19. Map showing water-level changes in the Equus Beds aquifer in the study area, August 1940 to July 2009

20. Map showing water-level changes in the Equus Beds aquifer in the study area, August 1940 to January 2010.

21. Map showing water-level changes in the Equus Beds aquifer in the study area, August 1940 to October 1992

22. Map showing water-level changes in the Equus Beds aquifer in the study area, October 1992 to January 2010

23. Map showing water-level changes in the Equus Beds aquifer in the study area, January 2007 to January 2010

24. Graph showing comparison of storage-volume changes in the study area for selected periods

25. Graph showing statistical relation between storage volume and pumpage in the study area, 1993-2009

\section{Tables}

1. Storage-volume changes in Equus Beds aquifer near Wichita, south-central Kansas, August 1940 to January 2010

2. Average annual precipitation, irrigation and city of Wichita annual pumpage, annual artificial recharge, and aquifer storage-volume changes in the study area near Wichita, south-central Kansas, 1988-2009.

3. Average annual total pumpage, aquifer storage-volume change, and precipitation in the study area near Wichita, south-central Kansas, for selected time periods 


\section{Appendix}

\section{Tables}

A1. Streamflow-gaging stations and observation wells in the Equus Beds aquifer, south-central Kansas. .44

A2. Precipitation stations in and near the study area, south-central Kansas . .47

\section{Conversion Factors}

\begin{tabular}{|c|c|c|}
\hline Multiply & By & To obtain \\
\hline \multicolumn{3}{|c|}{ Length } \\
\hline inch (in.) & 25.4 & millimeter (mm) \\
\hline foot (ft) & 0.3048 & meter $(\mathrm{m})$ \\
\hline mile (mi) & 1.609 & kilometer $(\mathrm{km})$ \\
\hline \multicolumn{3}{|c|}{ Area } \\
\hline square mile $\left(\mathrm{mi}^{2}\right)$ & 2.590 & square kilometer $\left(\mathrm{km}^{2}\right)$ \\
\hline \multicolumn{3}{|c|}{ Volume } \\
\hline acre-foot (acre-ft) & 1,233 & cubic meter $\left(\mathrm{m}^{3}\right)$ \\
\hline \multicolumn{3}{|c|}{ Flow rate } \\
\hline acre-foot per year (acre-ft/yr) & 1,233 & cubic meter per year $\left(\mathrm{m}^{3} / \mathrm{yr}\right)$ \\
\hline inch per year (in/yr) & 25.4 & millimeter per year $(\mathrm{mm} / \mathrm{yr})$ \\
\hline
\end{tabular}

Temperature in degrees Celsius $\left({ }^{\circ} \mathrm{C}\right)$ may be converted to degrees Fahrenheit $\left({ }^{\circ} \mathrm{F}\right)$ as follows:

$$
{ }^{\circ} \mathrm{F}=\left(1.8 \mathrm{x}^{\circ} \mathrm{C}\right)+32
$$

Temperature in degrees Fahrenheit $\left({ }^{\circ} \mathrm{F}\right)$ may be converted to degrees Celsius $\left({ }^{\circ} \mathrm{C}\right)$ as follows:

$$
{ }^{\circ} \mathrm{C}=\left({ }^{\circ} \mathrm{F}-32\right) / 1.8
$$

Prior to April 2000, vertical coordinate information is referenced to the National Geodetic Vertical Datum of 1929 (NGVD 29). For April 2000 and after, vertical coordinate information is referenced to North American Vertical Datum of 1988 (NAVD 88). NAVD 88 vertical coordinates are about $0.5 \mathrm{ft}$ higher than NGVD 29 vertical coordinates in the part of south-central Kansas discussed in this report.

Horizontal coordinate information is referenced to the North American Datum of 1983 (NAD 83).

Altitude, as used in this report, refers to distance above the vertical datum. 



\title{
Status of Groundwater Levels and Storage Volume in the Equus Beds Aquifer near Wichita, Kansas, January 2006 to January 2010
}

\author{
By Cristi V. Hansen and Walter R. Aucott
}

\section{Abstract}

A part of the Equus Beds aquifer in southwestern Harvey County and northwestern Sedgwick County was developed to supply water to residents of Wichita and for irrigation in south-central Kansas. Groundwater pumping for city and agricultural use caused water levels to decline in a large part of the aquifer northwest of Wichita. In 1965, the city of Wichita began using water from Cheney Reservoir in addition to water from the Equus Beds aquifer to meet the city's increasing demand for water. Irrigation pumpage in the area increased substantially during the 1970 s and 1980 s and contributed to the water-level declines. Water-level declines reached their maximum to date in October 1992.

Proposals to artificially recharge the aquifer have been made since the 1950 s to meet future water-supply needs and to protect the aquifer from the intrusion of saltwater from sources to the south and west. In 2007, Wichita implemented Phase 1 of the Equus Beds Aquifer Storage and Recovery project for large-scale artificial recharge of the aquifer.

A period of water-level rises associated with greaterthan-average precipitation and decreased city pumpage from the area began in 1993 and continued through January 2010. During January 2010, the direction of groundwater flow in the Equus Beds aquifer in the area was generally from west to east, similar to the direction prior to development of the aquifer. Water-level changes since 1940 for the period January 2006 to January 2010 ranged from a decline of more than 30 feet to a rise of more than 4 feet. Almost all wells in the area had cumulative water-level rises from October 1992 (period of maximum storage loss) to January 2010 and from January 2007 (beginning of large-scale artificial recharge) to January 2010. The average cumulative water-level change from October 1992 to January 2010 was a rise of about 8.7 feet and from January 2007 to January 2010 was a rise of about 3.2 feet.

The storage-volume change in the study area for the period October 1992 to January 2010 represented a recovery of about 183,000 acre-feet, or about 65 percent of the storage volume previously lost from August 1940 to October 1992, and was the largest recovery since October 1992 to date. Decreased city pumpage and artificial recharge during 1993-2009 and 2007-09 contributed to the recovery of storage volume in both periods, but artificial recharge's contribution was much smaller. Irrigation pumpage, because it increased during 1993-2009, did not contribute to the recovery of storage volume from October 1992 to January 2010. Recharge from excess precipitation contributed to the recovery of storage volume in both periods because precipitation averaged about 2 and 6 inches per year more than the annual long-term average of 31.52 inches during 1993-2009 and 2007-09, respectively.

Sustainable yield for the Equus Beds aquifer in the study area was estimated to be about 57,000 acre-feet per year using two different methods. The sum of permitted annual irrigation (about 45,600 acre-feet) and city (about 31,400 acre-feet) pumpage of 77,000 acre-feet per year greatly exceeds the estimated sustainable yield. Effective water management, including additions to the water budget such as those from the Equus Beds Aquifer Storage and Recovery project, can help produce the most water for beneficial use in a more sustainable way.

\section{Introduction}

A part of the Equus Beds aquifer in southwestern Harvey County and northwestern Sedgwick County was developed to supply water to residents of Wichita and for irrigation in the study area in south-central Kansas (fig. 1). On September 1, 1940, Wichita began pumping from 25 wells completed in the aquifer in the central part of the study area (Stramel, 1956) (fig. 1). By 1959, there were an additional 30 wells in use by the city of Wichita (Stramel, 1967). Groundwater pumpage from the aquifer for city and agricultural use has caused water levels to decline in a large part of the study area. A substantial part of the decline in water levels occurred from 1940 until the drought of the 1950s ended in early 1957 (Stramel, 1967). In 1965, the city of Wichita began using water from Cheney Reservoir (Stramel, 1967) in addition to water from the Equus Beds aquifer to meet the city's increasing demand for water. Groundwater pumpage for irrigation in the study 


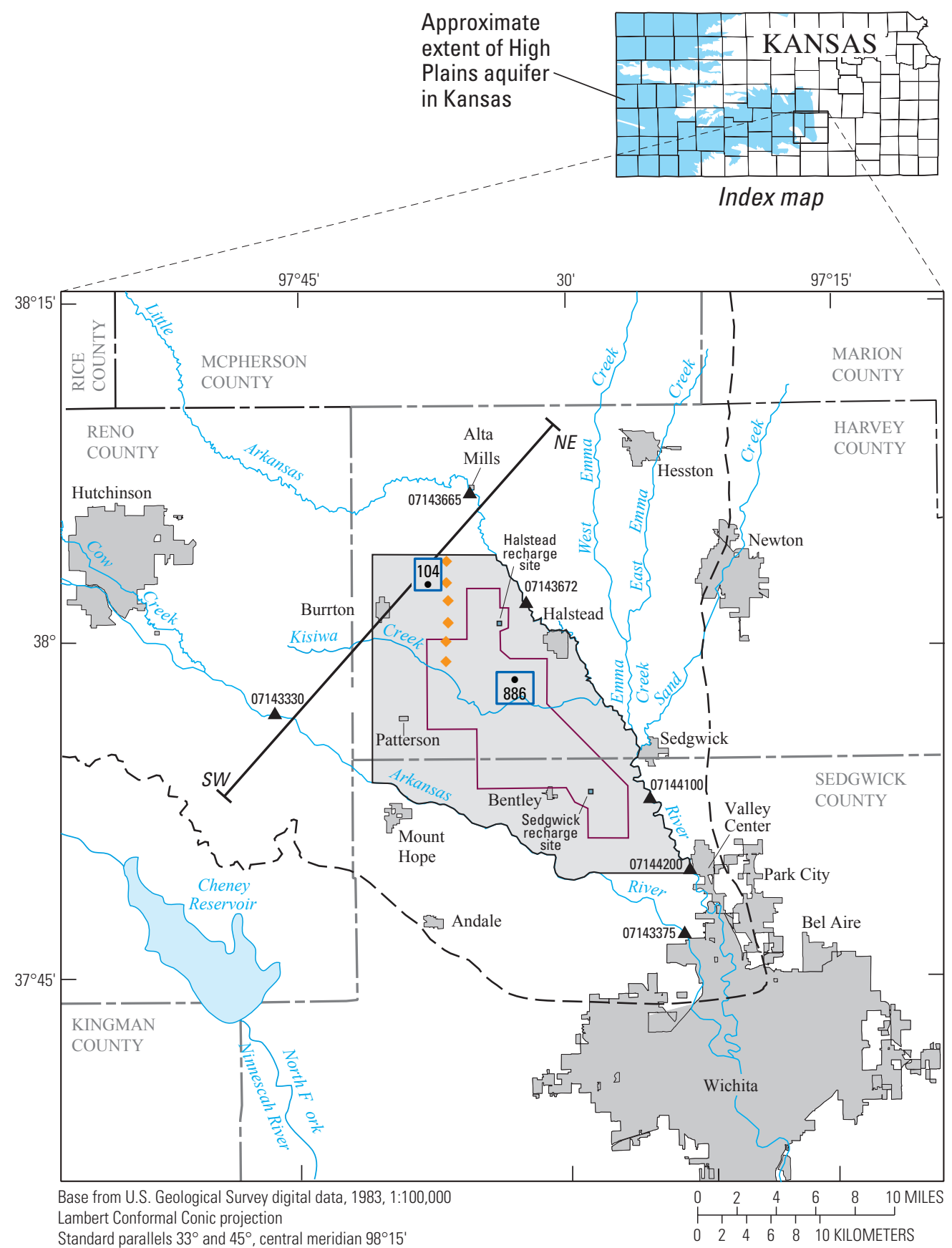

Standard parallels $33^{\circ}$ and $45^{\circ}$, central meridian $98^{\circ} 15^{\prime}$

\section{EXPLANATION}

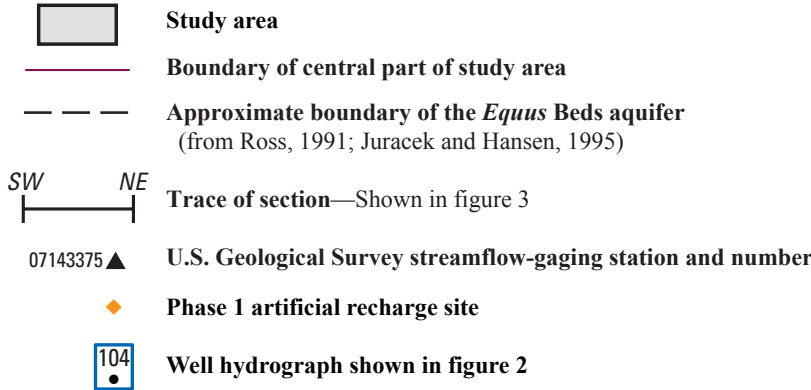

Figure 1. Location of study area near Wichita, south-central Kansas (modified from Aucott and Myers, 1998). 
area increased substantially during the 1970s and 1980s and contributed to the water-level declines (Spinazola and others, 1985; Myers and others, 1996; Aucott and Myers, 1998), which became greatest in October 1992 (Hansen and Aucott, 2001). Long-term water-level declines can be attributed to municipal and irrigation groundwater pumpage; however, changes in precipitation (and thus recharge to the Equus Beds aquifer) also have had short-term effects on water levels.

The Equus Beds Groundwater Management District No. 2 (GMD2) was formed in 1975 as part of the effort to balance the factors affecting water levels in the Equus Beds aquifer, to efficiently manage the use of water from the aquifer, and to preserve the aquifer for future generations. GMD2 has developed a management program that is based on the "aquifer safe yield principle." The aquifer safe yield principle limits the annual amount of groundwater pumpage to the annual amount of groundwater recharge as noted in the management program of GMD2 (Equus Beds Groundwater Management District No. 2, 1995). GMD2 also manages the aquifer based on the groundwater-quality principle "which seeks to maintain by protection and remediation the naturally occurring quality of the aquifer" (Tim Boese, written commun., Equus Beds Groundwater Management District No. 2, July 2010).

Proposals to artificially recharge the Equus Beds aquifer have been made since the 1950s (for example, Stramel, 1956; Albert and Stramel, 1966) to meet future water-supply needs and to protect the aquifer from the intrusion of saltwater from natural and human-related sources to the south and west (Warren and others, 1995). A small pilot project by the city of Wichita in the early 1980s indicated that it would be possible to artificially recharge the Equus Beds aquifer (Hufford, [1983?]). In the late 1990s and early 2000s, the Equus Beds Groundwater Recharge Demonstration Project, a trial project to prove the feasibility of artificially recharging the aquifer on a large scale, successfully diverted more than 1 billion gallons (about 3,300 acre-ft) of water from the Little Arkansas River and stored it in the Equus Beds aquifer (Wichita Water Utilities, [2008?]; U.S. Geological Survey, 2006). In March 2006, the city of Wichita followed up the success of the Demonstration Project by starting construction of the Equus Beds Aquifer Storage and Recovery (ASR) project to artificially recharge the Equus Beds aquifer on a large scale. Other entities involved with the ASR project include GMD2 (Halstead, Kansas), Kansas Department of Agriculture, Kansas Department of Health and Environment, Kansas Water Office, Bureau of Reclamation (U.S. Department of the Interior), U.S. Environmental Protection Agency, U.S. Geological Survey (USGS), and various local interest groups and private consulting and engineering firms. Phase 1 of the ASR project was completed in 2006 and large-scale artificial recharge of the aquifer began at the Phase 1 sites in March 2007. The Phase 1 sites (fig.1) use water from the Little Arkansas River-pumped from the river directly or from wells in the riverbank that obtain their water from the river by induced infiltration - as the source of artificial recharge to the Equus Beds aquifer (Wichita Water Utilities, [2007?]). Water is only allowed to be diverted from this river for artificial recharge when flows are greater than minimums set by the State of Kansas (Approval of Application to Appropriate Water Application File Nos. 45567 through 45576, 46081, and 46578, Kansas Department of Agriculture, Division of Water Resources, Topeka, Kansas, August 8, 2005 and February 19, 2007).

The USGS and the city of Wichita have worked cooperatively since 1940 in evaluating the Equus Beds aquifer and its interaction with streams in the area to further the understanding of the entire hydrologic system and to provide information to aid local decision making (Williams and Lohman, 1949). This study has developed a baseline condition for evaluating the effects of artificial recharge on groundwater levels in the Equus Beds aquifer, documented changes in historical hydrologic conditions and the probable causes of these changes in the study area, and reviewed changes in the groundwater-flow system. The understanding gained from this cooperative study of the hydrologic system and the Equus Beds aquifer also helps contribute to the wise management of water resources where similar hydrologic conditions exist elsewhere.

\section{Purpose and Scope}

The purpose of this report is to describe the status of groundwater levels and storage volume in the Equus Beds aquifer northwest of Wichita during January 2006 to January 2010 as compared with predevelopment (before large-scale withdrawals began in September 1940) groundwater levels and to update historical information related to changes in the aquifer storage since 1940. Maps of groundwater-level measurements and water-level changes are presented. Two hydrographs of groundwater levels were selected to show historical water-level variations. Historical water-use and climate information also are presented. Information in this report can be used to document and improve understanding of the effects of climate, water-use, and water-resource management practices on water supplies in the Equus Beds aquifer, an important source of water for the city of Wichita and the surrounding area.

\section{Methods}

\section{Water Levels}

Groundwater-level measurements from two observationwell networks were used in this report. The two networks are the Equus Beds historic observation well network and the areal index well network. Data collection from the Equus Beds historic observation well network began just prior to the beginning of city pumpage from the aquifer in the study area in 1940 with water-level measurements from about 50 wells (Williams and Lohman, 1949). The network was expanded until it included more 200 wells in 1955 (Stramel, 1957). Currently (2010), water-level measurements from more than 100 
Groundwater Levels and Storage Volume in the Equus Beds Aquifer near Wichita, Kansas

of these wells (table A1 in Appendix) are used to construct the water-level-altitude and water-level-change maps used in this report. Water levels in the historic Equus Beds observation well network are measured at least quarterly by the city of Wichita personnel.

The areal index observation well network contains 38 pairs of wells in and near the study area that were installed for the city of Wichita during 2001 and 2002. Each pair of areal index wells consists of a well completed in the upper part of the aquifer and another well completed in the lower part of the aquifer. These wells were designed for use by the city to monitor the water quality and water levels in the aquifer throughout the study area and any changes that might occur as a result of the artificial recharge project. These wells also were used to determine if there are any water-quality differences between the shallow and deep parts of the aquifer (Andrew Ziegler, U.S. Geological Survey, oral commun., September 2003). As water levels also can be measured in these wells, the wells were added to the water-level monitoring network in the study area in 2002. For mapping purposes, the water levels from the shallow well at the site of each pair of areal index wells were used, except at the three most northwesterly pairs of areal index well sites. Water levels from the deep wells in these three pairs (USGS site identification numbers 380130097385002,380329097363702 , and 380421097385002) were used because they best represent the part of the aquifer open to the historic observation wells in this part of the study area (table A1 in the Appendix). The selection of the wells used for mapping purposes from each of the 38 pairs of areal index wells previously was described in Hansen and Aucott (2004). Water levels in the areal index well network are measured quarterly by GMD2 personnel and occasionally by USGS personnel; all areal index well waterlevels used in this report were measured by GMD2.

The city of Wichita and GMD2 use standard water-level measurement techniques similar to those described in Stallman (1971). Water levels for the Equus Beds historic observation well network are on file in paper and electronic form with the city of Wichita Water and Sewer Department in Wichita, Kansas, and are stored by the USGS in the National Water Information System (NWIS) database and are available at the following URL: http://waterdata.usgs.gov/ks/nwis. Water levels measured in the areal index observation wells by the USGS and GMD2 also are stored in the NWIS database and are available at this URL.

Average daily surface-water-altitude measurements from data automatically collected by equipment at six USGS streamflow-gaging stations on the Arkansas and Little Arkansas River in and near the study area (fig. 1; table A1 in Appendix) were used to estimate the surface-water altitude along these streams. If the associated groundwater-level measurements were collected over several days, each streamflowgaging station's average surface-water altitude for the day at the midpoint of the measurement period was used. These measurements were used along with the groundwater-level measurements in the construction of the water-level altitude map created for this report.

In NWIS, surface-water levels are stored as the watersurface's height (gage height) above an altitude at which there will be zero flow at the gage (gage datum). Groundwater levels are stored in NWIS as depth to water below land surface. The water-level altitude at a streamflow-gaging station was computed by adding the gage height to the altitude of the gage datum. The water-level altitude at a well was computed by subtracting the depth to water at the well from the well's land-surface altitude. Surface-water and groundwater-level altitudes were used to construct water-level altitude maps for this report. The water-level change at a well for a selected time period was computed as the depth to water at the well at the beginning of the time period minus the depth to water at the well at the end of the time period. August 1940 is the beginning of most of the time periods used in this report. Most of the wells used in this report did not exist or have a measured water level in August 1940; for these wells, a 1940 water-level measurement was interpolated from the August 1940 waterlevel-altitude map. Only measured water levels were used for other dates.

As a measure of quality control, each well's water levels for the period of record are plotted as a hydrograph, usually with the water levels of a nearby well on the same graph, and visually inspected. Those water level measurements that do not fit the expected pattern are researched and if no logical explanation for the aberration can be found, the water level is not used for mapping purposes.

\section{Precipitation}

Precipitation data for 1938-2009 for nine Cooperative and Weather Bureau Army Navy (WBAN) weather stations in and near the study area were used to estimate the annual precipitation for the study area. Stations used for this report and the periods of data used are shown in table A2 in the Appendix. During 1938-47, only three precipitation stations were active in or near the study area; data from five active stations in and near the study area were used for the 1948-2009 period. If a station did not have annual precipitation data for the entire 1948-2009 period, a nearby station was used for the remaining part of this period. For a station without annual data because of partial precipitation record in some months, the daily data for the partial months were inspected, the precipitation for the missing days was estimated from the precipitation at nearby stations by interpolation, the total for the month calculated, and the monthly data summed for the estimated annual precipitation for the station. The annual precipitation for the study area was estimated as the arithmetic average of the annual precipitation of the stations used for the year. The long-term average precipitation used in this report is the average of the 1938-2009 precipitation for the study area. The 5-year moving average of precipitation used in this report was determined by taking the annual precipitation for the study area and averaging it for each 5-year period. Because past precipitation can 
affect current groundwater levels but future precipitation cannot, the 5-year moving average of precipitation is plotted at the end of the 5-year period.

\section{Specific Yield}

The specific yield of the Equus Beds aquifer has been estimated by many investigators using a variety of methods; these methods include aquifer tests, laboratory analyses of aquifer samples, lithologic descriptions from drillers' logs, water-balance equations, and parameter estimation for groundwater models. Estimates of specific yield from these methods have ranged from less than 0.1 to more than 0.3 with most estimates in the range of 0.15 to 0.2 (Williams and Lohman, 1949; Stramel, 1956, 1967; Kansas Water Resources Board, 1960; Bayne and Ward, 1969; Lohman, 1979; Gutentag and others, 1984; Reed and Burnett, 1985; Spinazola and others, 1985; Stullken and others, 1985; Hansen, 1991; Nathan C. Myers, USGS, written commun., 1996; Cederstrand and Becker, 1998; and David Stous and Patrick Higgins, Burns and McDonnell Engineering Consultants, written commun., 2000). A specific yield of 0.2 has been used to compute the changes in storage volume in the Equus Beds aquifer since Stramel (1956) first computed storage volume for the aquifer. The use of a specific yield of 0.2 was retained in this report because, as reported by Hansen and Aucott (2001), it is within the range of most estimates of specific yield and because there is no general agreement on an average value of specific yield for the Equus Beds aquifer in the study area.

\section{Storage-Volume and Pumpage Changes}

The changes in storage volume since August 1940 for the selected time periods used in this report were computed using computer-generated Thiessen polygons (Thiessen, 1911) that were based on the measured water-level changes at wells and the manually drawn lines of equal water-level change. Thiessen polygons apportion the water-level change at each well and at points representing the lines of equal water-level change to the area around the wells and points. The storagevolume change was computed by summing the area of each Thiessen polygon multiplied by the actual water-level change value associated with the Thiessen polygon and then by the specific yield. This computation was done for the Thiessen polygons within the whole study area and for those within the central part of the study area to determine the storage-volume change since August 1940 in each of these areas. Storage-volume changes for periods that begin at a time other than August 1940 were computed as the storage-volume change since 1940 to the end of the selected time period minus the storage-volume change at the beginning of the selected time period. For example, the storage-volume change for the period 1993-2009 would be would be calculated as the storage volume change from August 1940 to January 2010 minus the storage volume change from August 1940 to January 1993.
Irrigation and city pumpage changes were calculated as the pumpage for each year of the selected time period minus the pumpage at the beginning of the selected time period. These annual amounts were then totaled to get the cumulative change for the selected time period. For example, for the time period 1993-2009, the annual city pumpage for 1993 was subtracted from the annual pumpage for the years 1993-2009 and then the results summed to get the cumulative change in irrigation pumpage for the period.

\section{Description of Study Area}

The study area (fig. 1) includes about $165 \mathrm{mi}^{2}$ of the Equus Beds aquifer and is located in Harvey and Sedgwick Counties northwest of Wichita, Kansas. The study area is in the Arkansas River section of the Central Lowlands physiographic province (Schoewe, 1949). The land surface has little topographic relief and, for the most part, slopes gently toward the major streams in the study area. The study area is bounded on the southwest by the Arkansas River and on the northeast by the Little Arkansas River. The approximately $55 \mathrm{mi}^{2}$ central part of the study area (fig. 1), which is referred to throughout the report, is the historic center of pumping in the study area. The central part of the study area includes irrigation wells and most of the wells that supply water to the city of Wichita.

South-central Kansas has a continental climate that is characterized by large variations in seasonal temperatures, moderate precipitation, and windy conditions. In Wichita, Kansas, long-term daily normal temperatures for 1971-2000 ranged from $30.2^{\circ} \mathrm{F}$ in January to $81.0^{\circ} \mathrm{F}$ in July (National Oceanic and Atmospheric Administration, 2002b). The longterm (1940-2009) annual average precipitation for 1940-2009 at weather stations in or near the study area (at Halstead, Hutchinson, Mount Hope, Newton, Sedgwick, and Wichita) is 31.52 in. (National Oceanic and Atmospheric Administration, 1998-2009; Mary Knapp, Kansas State Climatologist, written commun., February 1, 2010) (fig. 2A). However, annual precipitation values have ranged from about 46 to 152 percent of the long-term average for this time period (fig. $2 A$ ). The extent and severity of periods of greater-than or less-than average precipitation are shown distinctly by the 5 -year moving average (fig $2 A$ ). Since the end of the last reporting period in January 2006 (Hansen, 2006), precipitation was less than the long-term annual average during 2006 and greater than the long-term annual average during 2007-09 (fig. 2A).

\section{Previous Studies}

Water-level data have been collected periodically by the city of Wichita in the study area since 1940 and are on file with the city in Wichita, Kansas, and are stored in the NWIS database at $h t t p: / / w a t e r d a t a . u s g s . g o v / k s / n w i s$. Water-level data also have been collected by GMD2 since 1978 from wells completed in the Equus Beds aquifer (Equus Beds Groundwater Management District No. 2, 1995). Annual water-level data 

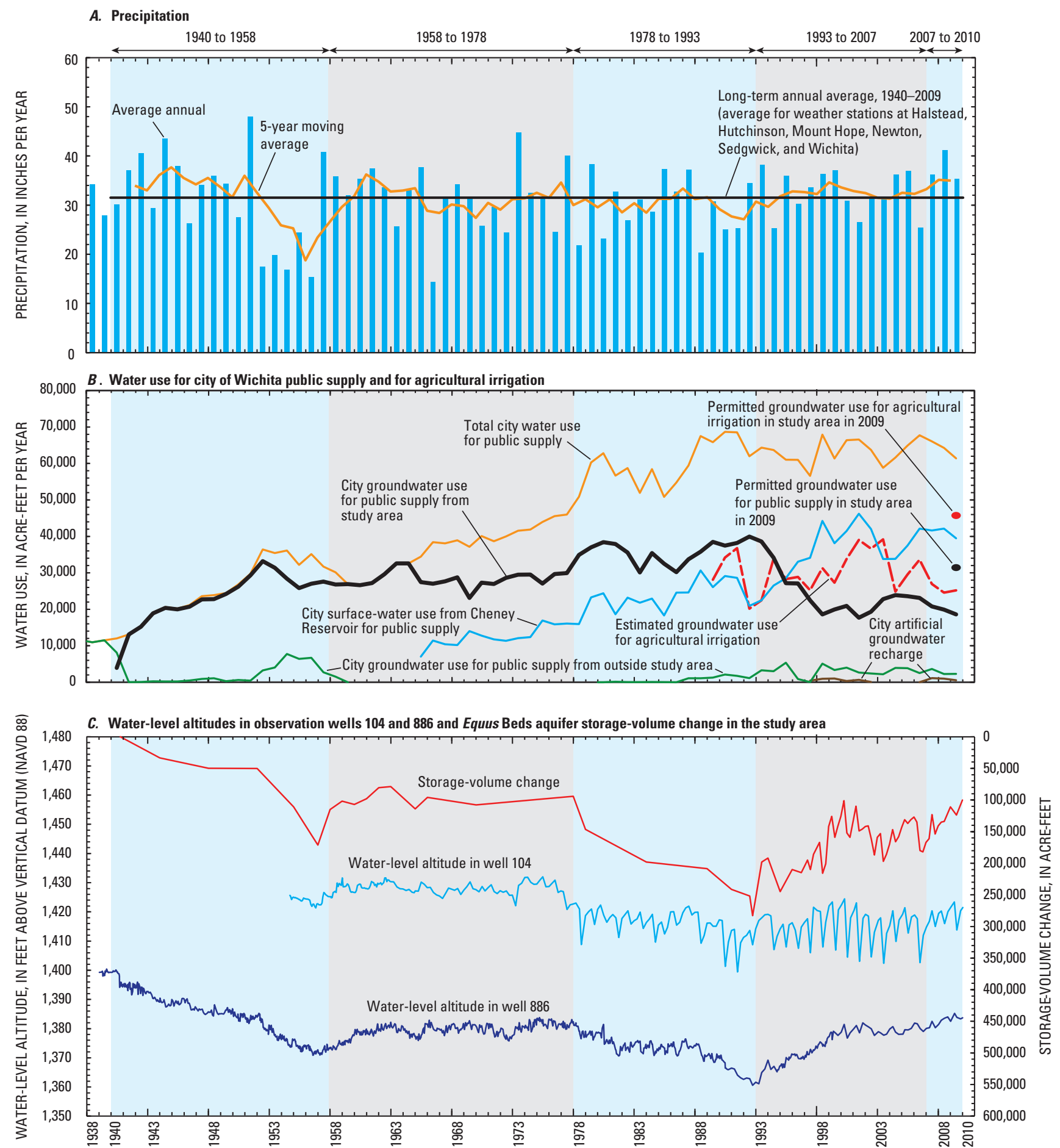

Figure 2. Relation of $(A)$ precipitation, $(B)$ water use for agricultural irrigation and by city of Wichita for public supply, and $(C)$ water-level altitudes in observation wells 104 and 886 and Equus Beds aquifer storage-volume change in study area 1938 to January 2010 (modified from Aucott and others, 1998). Source: (A) precipitation data from National Oceanic and Atmospheric Administration (1998-2010) and Mary Knapp (written commun., Kansas State Climatologist, February 1, 2010); (B) water-use data from Wichita Water Department [1959?], Stramel (1956, 1967), Gerald T. Blain (written commun., city of Wichita, 1997), Megan Schmeltz (written commun., city of Wichita, 2009), and Kansas Department of Agriculture, Division of Water Resources (unpublished data, 2010); (C) water-level altitude data from Stramel $(1956,1967)$ and from data collected by city of Wichita, Equus Beds Groundwater Management District No. 2, and on file with U.S. Geological Survey, Lawrence, Kansas. Location of observation wells is shown in figures 1 and 5. Storagevolume changes from Stramel (1956, 1967), Aucott and Myers (1998), Aucott and others (1998), Hansen and Aucott (2001, 2004), Hansen (2006, 2009a, 2009b) and data on file with U.S. Geological Survey in Lawrence, Kansas. 
for the High Plains aquifer (fig. 1), which includes the Equus Beds aquifer, have been collected since 1937 by the Division of Water Resources of the Kansas Department of Agriculture (DWR), USGS, and Kansas Geological Survey (KGS). The data on file with the USGS in Lawrence, Kansas are stored in the NWIS database and are available at http://waterdata. usgs.gov/ks/nwis; data on file with the KGS, including annual water-level data collected by KGS and DWR since 1997, are stored in the WIZARD database (Kansas Geological Survey, 2002). Historical and near-real-time data and reports associated with the USGS work on the Equus Beds aquifer (Ziegler and others, 1999; Ziegler and others, 2010) are available at http://ks.water.usgs.gov/Kansas/studies/equus/.

Williams and Lohman (1949), Stramel (1956, 1967), Lane and Miller (1965a), and Leonard and Kleinschmidt (1976) have published water levels and water-level decline maps for the study area; Williams and Lohman (1949) and Stramel (1956) also published water-level altitude maps for the study area. Ross and others (1997) noted water-level rises in the Equus Beds aquifer from 1993 to 1997 and attributed them largely to decreases in withdrawals by the city of Wichita. Aucott and Myers (1998), Aucott and others (1998), Hansen and Aucott (2001, 2004), and Hansen (2007, 2009a, $2009 \mathrm{~b}$ ) published water-level-decline maps for the study area and discussed the changes in storage volume for noteworthy past and recent periods of time. Myers and others (1996) evaluated the hydrologic interaction between the Arkansas River and the Equus Beds aquifer in the study area.

Water-level data for the High Plains aquifer, which includes the Equus Beds aquifer, have been compiled and mapped recently in Kansas by Mitchell and others (1993, 1994), Woods and others (1994, 1995, 1997, 1998, 1999, 2000), Woods and Schloss (1996), Woods and Sophocleous (2002, 2004), Olea and Davis (2003), Laflen and Miller (2003, 2004, 2005), Bohling and Wilson (2004, 2005, 2006), Young and others (2008), and Buddemeier and others (2010), and regionally by McGuire and Sharpe (1997), McGuire and Fischer (1999), McGuire (2001, 2003, 2004a, 2004b, 2007, 2009), and McGuire and others (2003).

\section{Geology and Groundwater}

Quaternary deposits occur throughout the study area primarily as alluvial deposits. These alluvial deposits, known locally as the Equus beds, are as much as $250 \mathrm{ft}$ thick in the study area (fig. 3). The Equus beds consist primarily of sand and gravel interbedded with clay or silt but locally may consist primarily of clay with thin sand and gravel layers (Lane and Miller, 1965a; Myers and others, 1996). The middle part of the deposits generally has more fine-grained material than the lower and upper parts (Lane and Miller, 1965b, Myers and others, 1996).

The Wellington Formation of Permian age underlies the Quaternary deposits in the study area and forms the bedrock confining unit below these deposits. The Wellington Formation is about $700 \mathrm{ft}$ thick (Bayne, 1956) and consists of three members - the lower anhydrite member, about $200 \mathrm{ft}$ thick; the Hutchinson Salt Member, about $300 \mathrm{ft}$ thick; and the upper shale member, about $200 \mathrm{ft}$ thick (Myers and others, 1996). Dissolution of the Hutchinson Salt Member resulted in subsidence of the overlying upper shale member, formation of low areas in the bedrock, and concurrent accumulation of alluvial deposits that now compose the Equus Beds aquifer (fig. 3) (Myers and others, 1996).

The Equus Beds aquifer is the easternmost extension of the High Plains aquifer in Kansas (Stulken and others, 1985; Hansen and Aucott, 2001). The Equus beds aquifer is an important source of groundwater because of the generally shallow depth to the water table, the large saturated thickness, commonly good permeability (Myers and others, 1996), and generally good water quality (Ziegler and others, 2010). Near the Arkansas River, the water table may be as little as $10 \mathrm{ft}$ below land surface. Farther from the Arkansas River and near the Little Arkansas River, the water table is at a greater depth, depending on the altitude of the land surface and the amount of water-level decline that has been caused by groundwater withdrawals. The maximum saturated thickness of the Equus Beds aquifer within the study area, almost $250 \mathrm{ft}$, is near the Arkansas River and corresponds to the lowest areas of the underlying bedrock surface (Spinazola and others, 1985). Hansen (2007) estimated the storage volume of the Equus Beds aquifer in the study area at about 2,100,000 acre-ft.

\section{Groundwater-Level Changes}

Groundwater-level declines can result from a combination of factors - pumpage, decreased recharge resulting from less-than-average precipitation, and other factors. Droughts, such as occurred during 1952-56 and 1988-92 (fig. 2A), decrease the amount of recharge available and increase demand for and thus use of groundwater (fig. $2 B$ ), resulting in increased water-level declines (fig. $2 C$ ). Periods of greaterthan-average rainfall, such as occurred in 1957-62 (fig. 2A), tend to increase the amount of recharge available and decrease the demand for and thus use of groundwater (fig. $2 B$ ), resulting in water-level rises (fig. 2C). Artificial recharge supplements the amount of recharge naturally available and may result locally in smaller water-level declines or, if large enough, in water-level rises. If the water-level declines or rises are large enough, they may alter the direction of local groundwater flow.

Description of noteworthy periods of water-level change in the study area is facilitated by the use of hydrographs of water levels in observation wells 104 and 886 (fig. 2C). The hydrograph of well 104 serves as a representative descriptor of agricultural irrigation effects near the northern edge of the study area; the hydrograph of well 886 serves as a representative descriptor of historical water-level changes in an area 


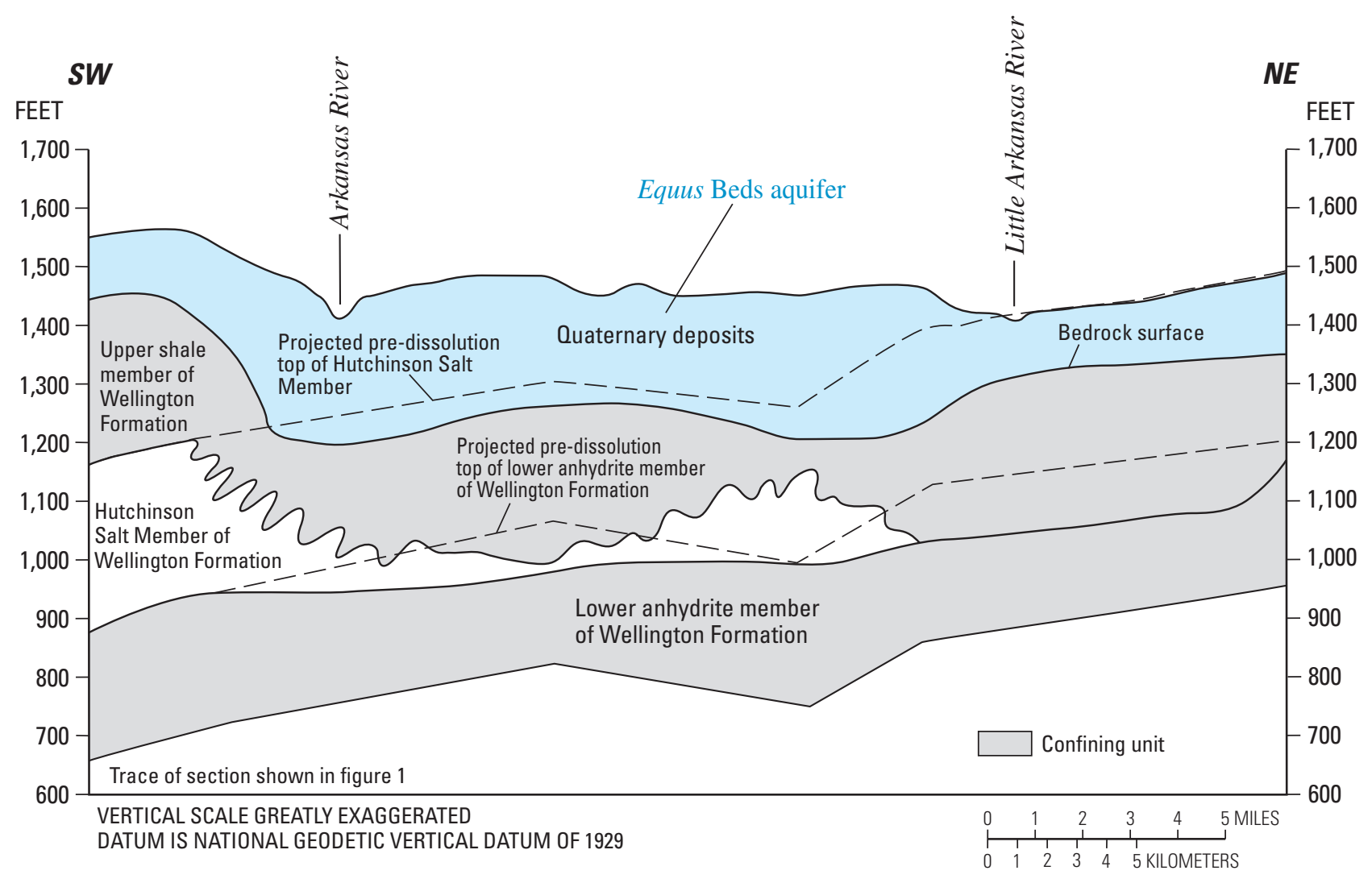

Figure 3. Generalized geologic section (from Leonard and Kleinschmidt, 1976; Myers and others, 1996).

of maximum water-level decline near the historic center of pumping by the city of Wichita in the central part of the study area (fig. 1).

Aucott and Myers (1998) identified four noteworthy periods of water-level change (fig. 2C): 1940 to 1958, the initial water-level decline period when pumpage began in the study area, which includes a phase of accelerated declines in the mid-1950s coinciding with drought conditions; 1958 to 1978 , a period of general equilibrium with relatively stable city pumpage and water levels and increasing irrigation pumpage that became of greater significance in the late 1970s; 1978 to 1993 , another period of water-level declines and increased city and irrigation pumpage because of increased demands and drought conditions; and 1993 to 1999, a period of water-level rises associated with generally greater-than-average precipitation and decreased city pumpage. The first three periods have been well documented by Aucott and Myers (1998) and will not be described in this report. The fourth period - the period of water-level rises seen by Aucott and Myers (1998) during 1993 to 1999 - continued through January 2010 as indicated by patterns of precipitation, pumpage, storage volume, and water levels shown in figure $2 A-C$. The fourth period also includes a small amount of artificial recharge from the Equus Beds Recharge Demonstration Project (fig. 2B). However, for the purposes of monitoring the effects of large-scale artificial recharge on the Equus Beds aquifer, a fifth period of waterlevel change is considered as starting in 2007 (fig. $2 A-C$ ). In March 2007, the city of Wichita began large-scale artificial recharge at the six Phase 1 ASR sites in the Equus Beds aquifer.

The consistently large seasonal water-level variations in well 104 probably are because of agricultural irrigation pumpage and subsequent recovery in the non-growing season. Irrigation water-use amounts prior to 1989 are not plotted in figure $2 B$ because of incomplete reporting of water-use data before 1989 (Lane Letourneau, Kansas Department of Agriculture, Division of Water Resources, oral commun., August 2, 2002). Reported water use for agricultural irrigation and public supply in the study area in 2009 were about 55 and 59 percent, respectively, of what is permitted by the State of Kansas (Kansas Department of Agriculture, Division of Water Resources, Topeka, Kansas, unpub. data, 2010) (fig. 2B); thus, increased irrigation or city use in the study area could become a more significant factor, especially during future dry years.

The use of groundwater hydrographs along with the use of maps of water-level altitudes and of water-level changes and the use of tables and graphs of changes in storage volume can provide a more complete picture of changes in hydrologic conditions than the use of any one of these graphic tools. Hydrographs of individual wells are important for indicating 
changes over time at a specific point and can be used to infer the effects of water-level changes at that point. Such effects could include dewatered shallow wells or increased pumping costs to lift water from greater depths. Water-level-altitude maps show the gradient and direction of groundwater flow over a large area at a particular time. A single water-levelaltitude map cannot indicate location or extent of the areas affected by water-level declines or rises or how great these declines or rises are. However, water-level-change maps can be used to illustrate the location, extent, and magnitude of water-level declines and rises. Tables and graphs showing changes in storage volume, which are derived from waterlevel-change maps and represent a decrease (or increase) in the groundwater resource available for use, are a good measure of the cumulative effects of pumping and climatic conditions on the aquifer.

To illustrate water-level conditions for selected periods, previously published water-level-altitude maps for August 1940 (fig 4; Stramel, 1956; Aucott and Myers, 1998) and October 1992 (fig 5; Hansen and Aucott, 2001) were used in addition to the water-level-altitude map for January 2010 that was constructed for this report (fig. 6). Water levels used for the January 2010 water-level altitude map (fig. 6) were measured in the historic observation wells by city of Wichita personnel during January 4 to 13, 2010, and in the areal index wells by GMD2 personnel during January 14 to 15, 2010 . Average daily surface-water-altitude measurements computed for January 10, 2010, from data automatically collected by equipment at six USGS streamflow-gaging stations on the Arkansas and Little Arkansas Rivers in and near the study area (fig. 1, table A1 in Appendix) were used to estimate the surface-water altitude along these streams as depicted in figure 6 . The average daily surface-water altitudes for January 10 , 2010, are shown for the three streamflow-gaging stations on the Little Arkansas River that are in the study area (fig. 6); no streamflow-gaging stations on the Arkansas River are in the study area (fig. 1).

Figures 4, 5, and 6, respectively, illustrate conditions for predevelopment (August 1940), record low water levels in October 1992, and current (January 2010) conditions. Prior to pumpage from the Equus Beds aquifer in 1940, near-predevelopment conditions existed in the study area (Williams and Lohman, 1949; Aucott and Myers, 1998). The August 1940 water-level-altitude map from Stramel (1956) that was modified by Aucott and Myers (1998) (fig. 4) shows that groundwater flowed generally from west to east and discharged to the Little Arkansas River. Water-level-altitude maps for August 1940 and January 1955 (Stramel, 1956); for January 1957, January 1970, January 1993, and January 1998 (Aucott and Myers, 1998); for January 1997 (Aucott and others, 1998); for October 1992 (fig. 5) and January 2000 (Hansen and Aucott, 2001); for April 2000 and January 2003 (Hansen and Aucott, 2004); for January 2006 (Hansen, 2007); and for January 2010 (fig. 6) indicate that following development, groundwater flow remained from west to east, but that the flow generally became more southeasterly and more parallel to the Little Arkansas River near the eastern edge of the central part of the study area between Halstead and Sedgwick.

Water-level change maps were constructed from available water-level data to show changes between August 1940 (predevelopment) and quarter-year intervals from January 2006 to July 2008 (figs. 7-17), between August 1940 and half-year intervals from January 2009 to January 2010 (figs. 18-20), between August 1940 and October 1992 (fig. 21), between October 1992 and January 2010 (fig. 22), and between January 2007 and January 2010 (fig. 23). The August 1940 to October 1992 period (fig. 21) was selected as representative of the cumulative change between predevelopment and the period of maximum water-level decline (Hansen and Aucott, 2001). The October 1992 to January 2010 period (fig. 22) was selected as representative of the cumulative change since the period of maximum water-level decline (Hansen and Aucott, 2001). The January 2007 to January 2010 period was selected as representative of the cumulative change since just before the beginning of large-scale recharge (fig. 23).

In constructing figures 7-20 and similar maps in recent reports showing water-level changes since August 1940 (Aucott and Myers, 1998; Aucott and others, 1998; Hansen and Aucott, 2001, 2004; Hansen, 2007, 2009a, 2009b), if a 1940 water-level measurement did not exist for a well in the study area, one was interpolated from the August 1940 waterlevel-altitude map (fig. 4). For all other dates, no interpolations were made; contours were drawn based only on measured water levels.

\section{Quarter-Year and Half-Year Intervals, 2006 to 2010}

The water-level changes since August 1940 for the period January 2006 to January 2010 (figs. 7-20) ranged from a decline of more than $30 \mathrm{ft}$ in a well about $2.5 \mathrm{mi}$ west-northwest of Halstead in the northern part of the study area in July 2006 (fig. 9) to a rise of more than $4 \mathrm{ft}$ in July 2007 at a well near the Little Arkansas River about 2 mi northwest of Halstead (fig. 13). The shapes of the water-level-change contours since August 1940 for the period January 2006 to January 2010 (figs. 7-20) are similar to those published for recent years (Aucott and Myers, 1998; Aucott and others, 1998; Hansen and Aucott, 2001, 2004; Hansen, 2007, 2009a, 2009b). Comparisons of figures 7-20 show the annual cycle of waterlevel declines and rises that generally occur in the study area. Typically, the largest water-level declines occur during the summer or fall when agricultural irrigation and city pumpage are greatest. During the period January 2006 to January 2010, this is shown most distinctly by the expansion of areas with water-level declines of $10 \mathrm{ft}$ or more on the July and October maps of water-level changes since August 1940 and the occurrence of areas with declines of $20 \mathrm{ft}$ or more on the July 2006, October 2007, and July 2009 maps (figs. 9, 10, 13, 14, 17, and 19). As vegetation and human water use decrease following 

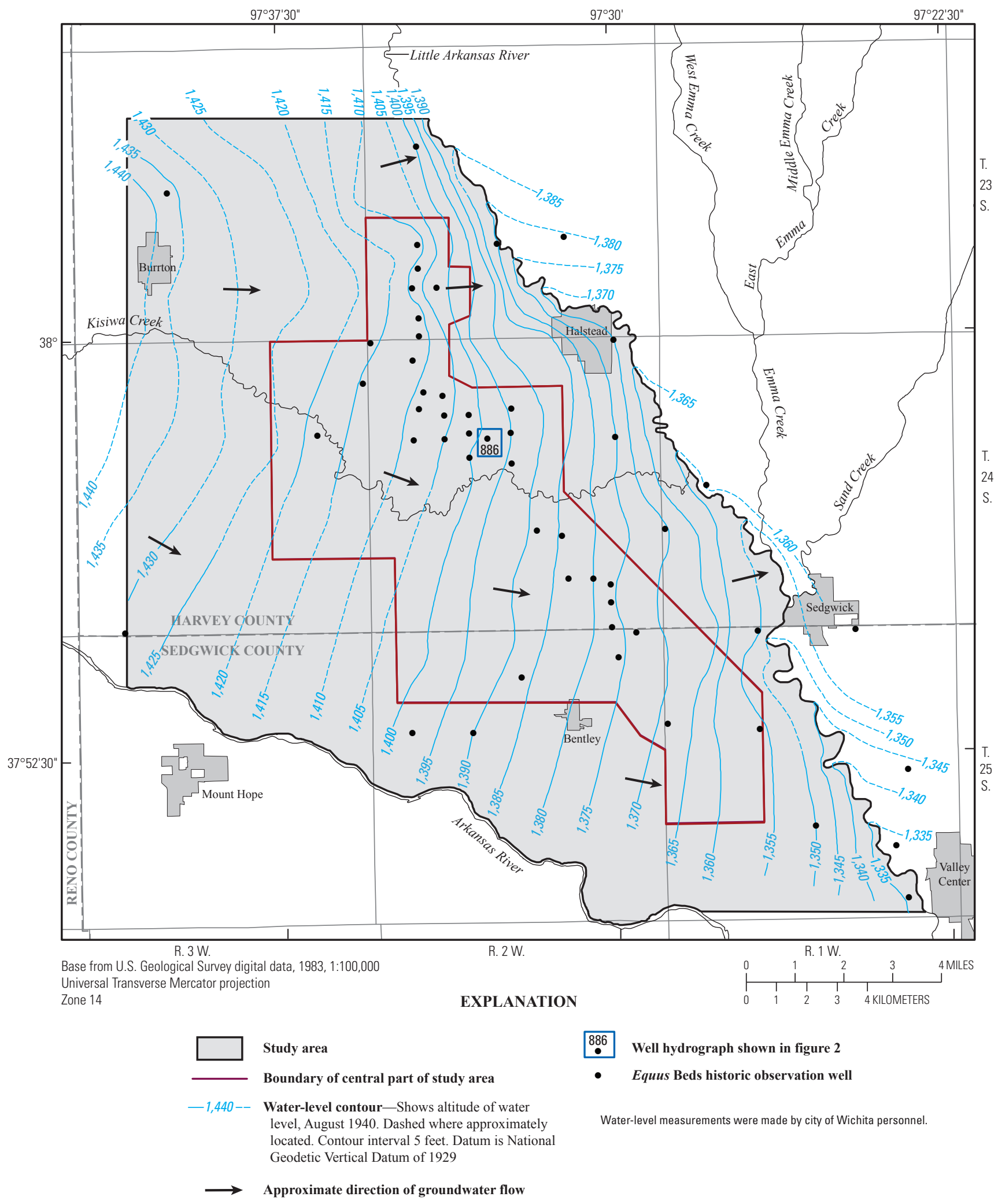

Figure 4. Water-level altitudes in the Equus Beds aquifer in the study area, August 1940 (modified from Stramel, 1956; Aucott and Myers, 1998). 


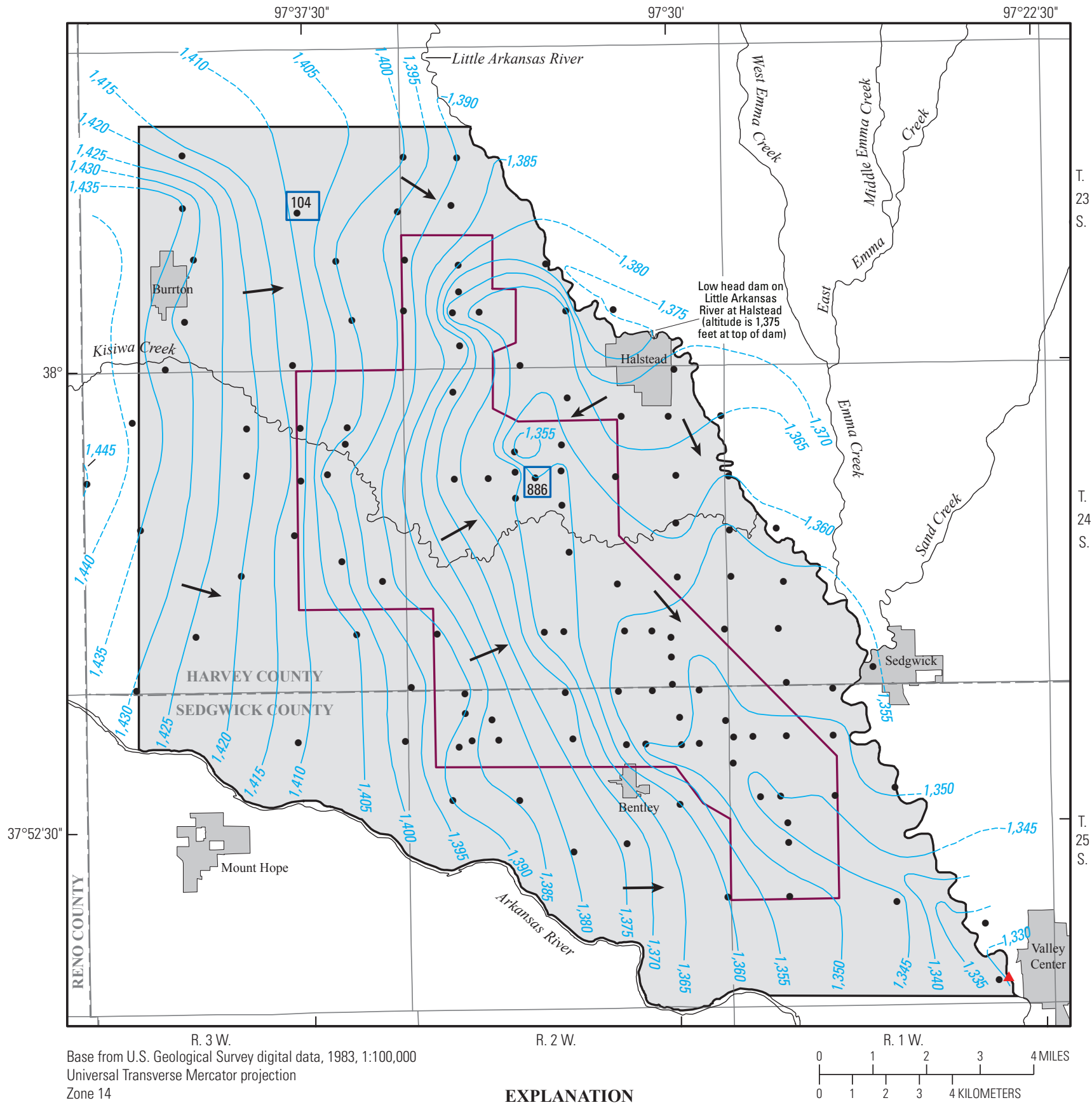

Universal Transverse Mercator projection

Zone 14

EXPLANATION

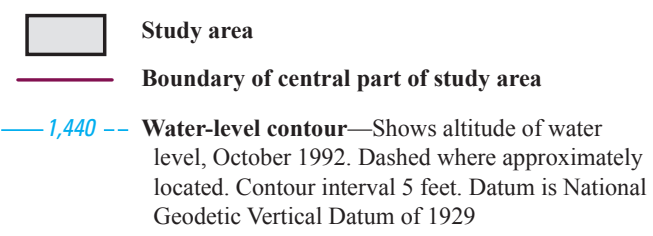

$\Delta \quad$ U.S. Geological Survey streamflow-gaging station

104 Well hydrograph shown in figure 2

- Equus Beds historic observation well

Geodetic Vertical Datum of 1929

Water-level measurements were made by city of Wichita personnel.

Figure 5. Water-level altitudes in the Equus Beds aquifer in the study area, October 1992 (modified from Hansen and Aucott, 2001). 


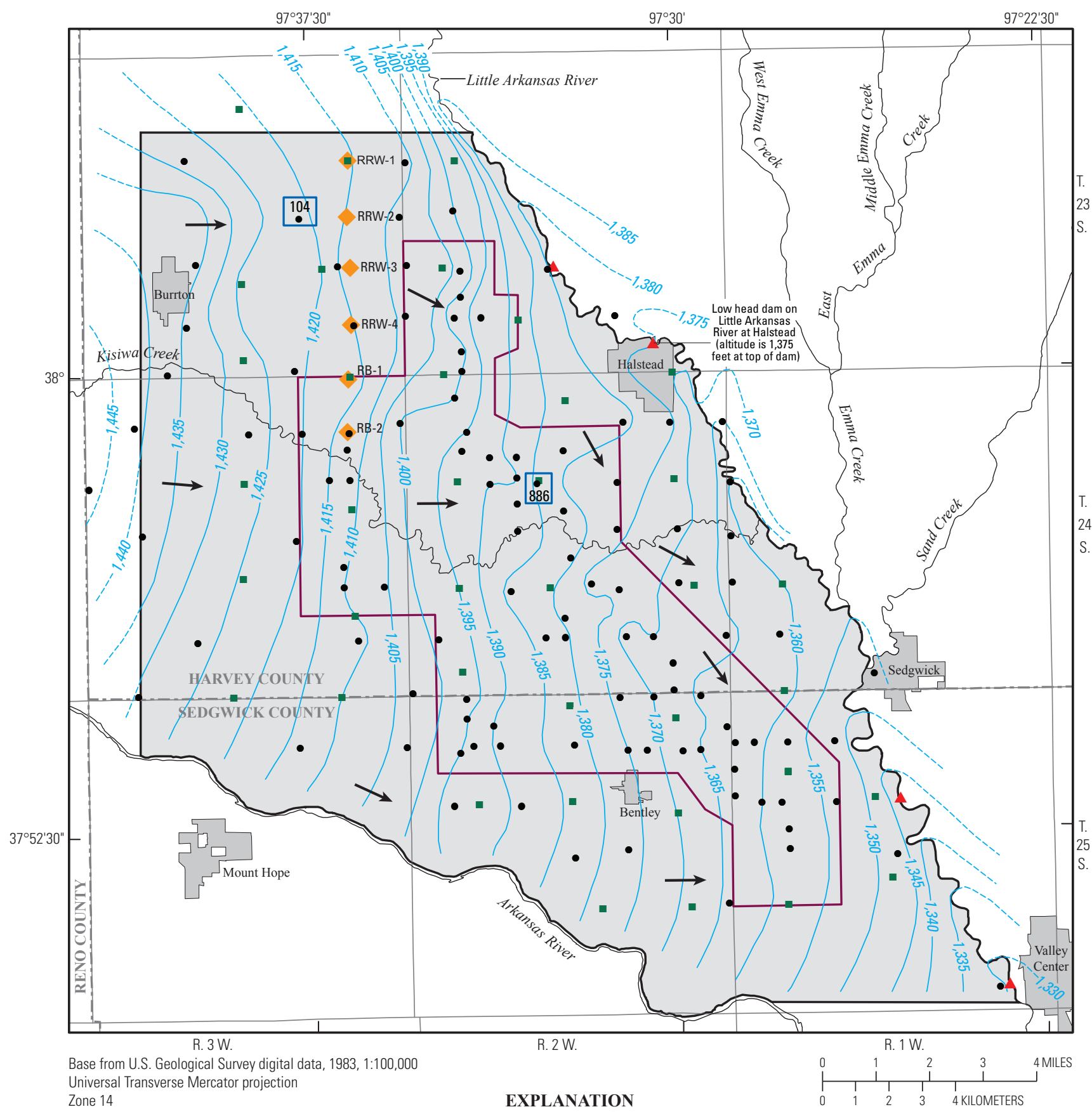

Study area

Boundary of central part of study area

1,425-- Water-level contour-Shows altitude of water level, January 2010. Dashed where approximately located. Contour interval 5 feet. Datum is North American Vertical Datum of 1988

$\longrightarrow$ Approximate direction of groundwater flow
$\Delta \quad$ U.S. Geological Survey streamflow-gaging station RRW-2 Phase 1 recharge site and identifier

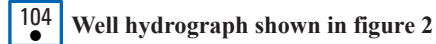

- Equus Beds historic observation well

- Equus Beds areal index well

Water-level measurements were made by city of Wichita and Equus Beds Groundwater Management District No. 2 personnel.

Water-level measurements at streamflow-gaging stations were collected by U.S. Geological Survey personnel.

Artificial recharge began March 2007 at Phase 1 sites

Figure 6. Water-level altitudes in the Equus Beds aquifer in the study area, January 2010. 


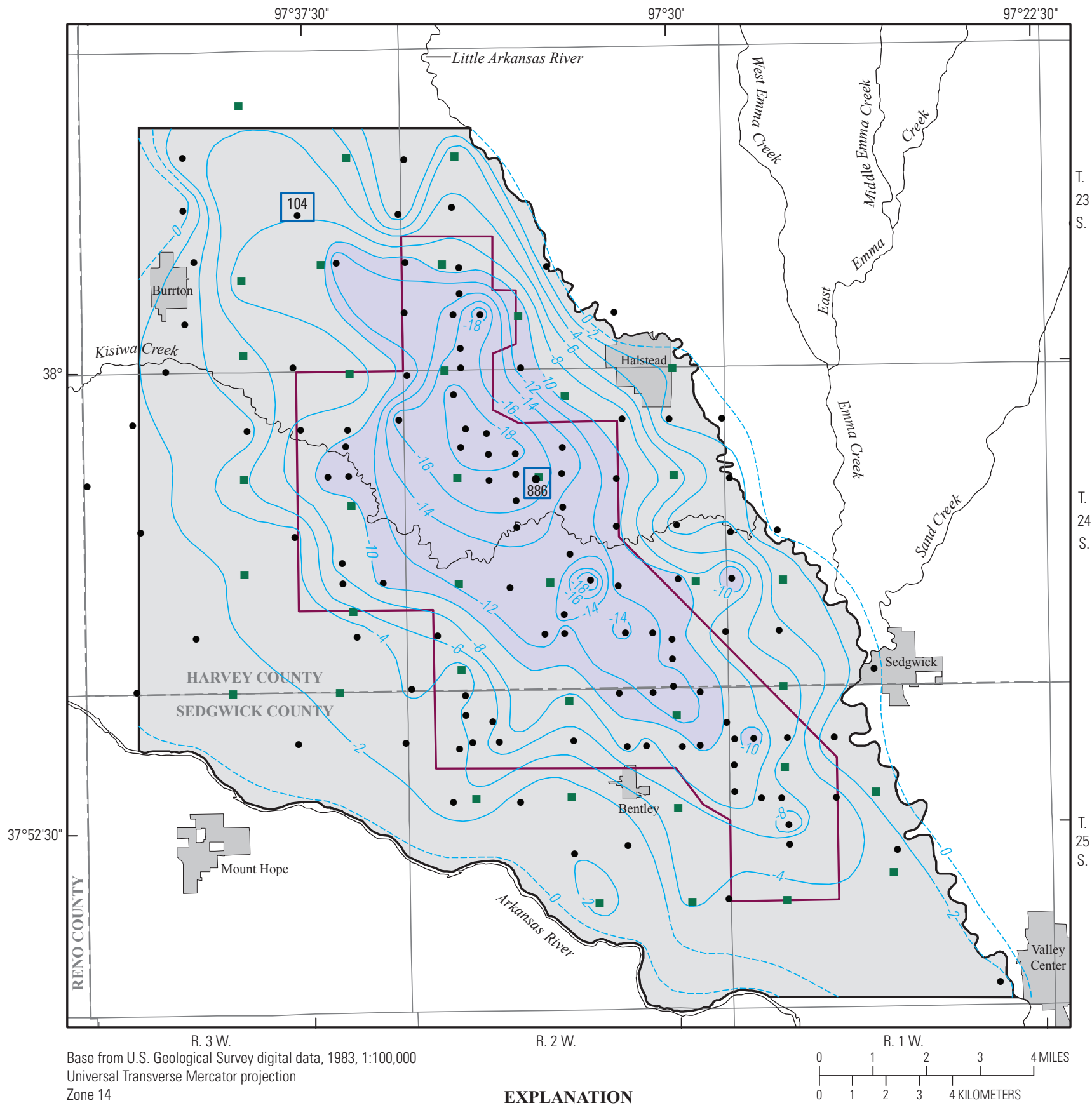

Zone 14

Area of water-level decline

Less than 10 feet

10 to less than 20 feet

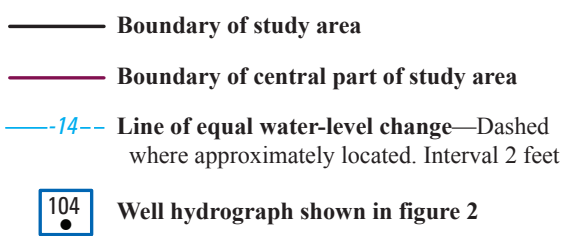

- Equus Beds historic observation well

- Equus Beds areal index well

Water-level measurements were made by city of Wichita and Equus Beds Groundwater Management District No. 2 personnel.

Depletion of storage volume in study area between August 1940 and January 2006 is 127,000 acre-feet.

Figure 7. Water-level changes in the Equus Beds aquifer in the study area, August 1940 to January 2006 (modified from Hansen and Aucott, 2007). 


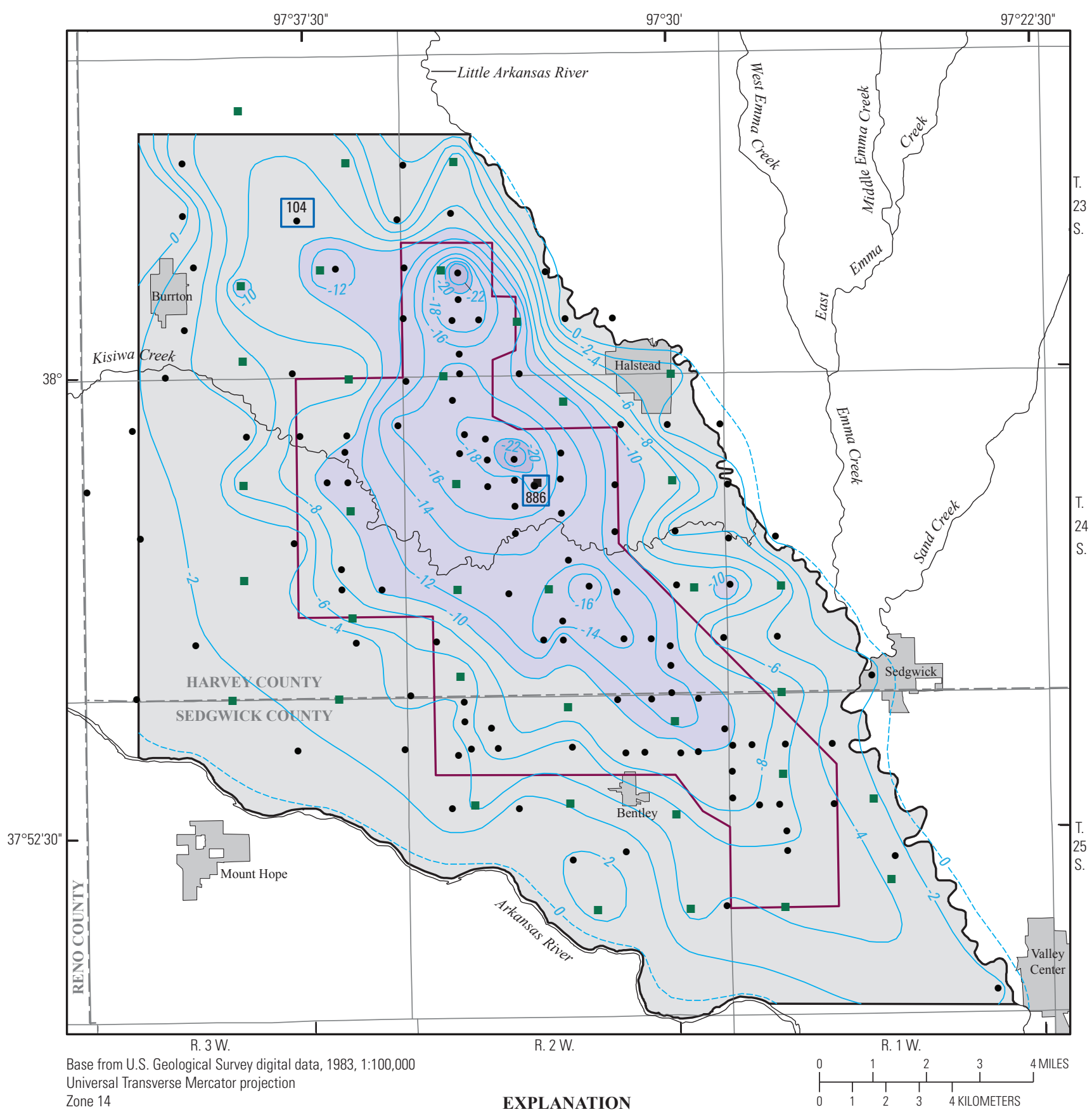

Universal Transverse Mercator projection Zone 14

EXPLANATION

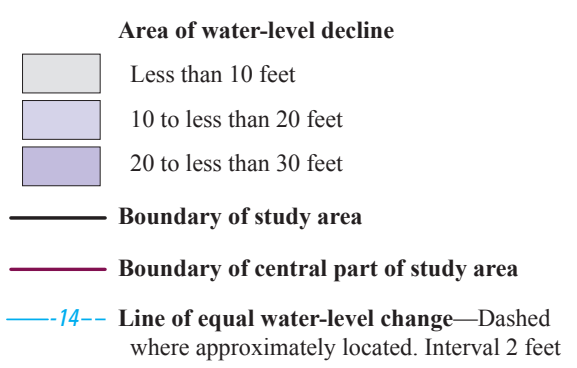

04
$\bullet$ Well hydrograph shown in figure 2

- Equus Beds historic observation well

- Equus Beds areal index well

Water-level measurements were made by city of Wichita and Equus Beds Groundwate Management District No. 2 personnel.

Depletion of storage volume in study area between August 1940 and April 2006 is 135,000 acre-feet

Figure 8. Water-level changes in the Equus Beds aquifer in the study area, August 1940 to April 2006. 


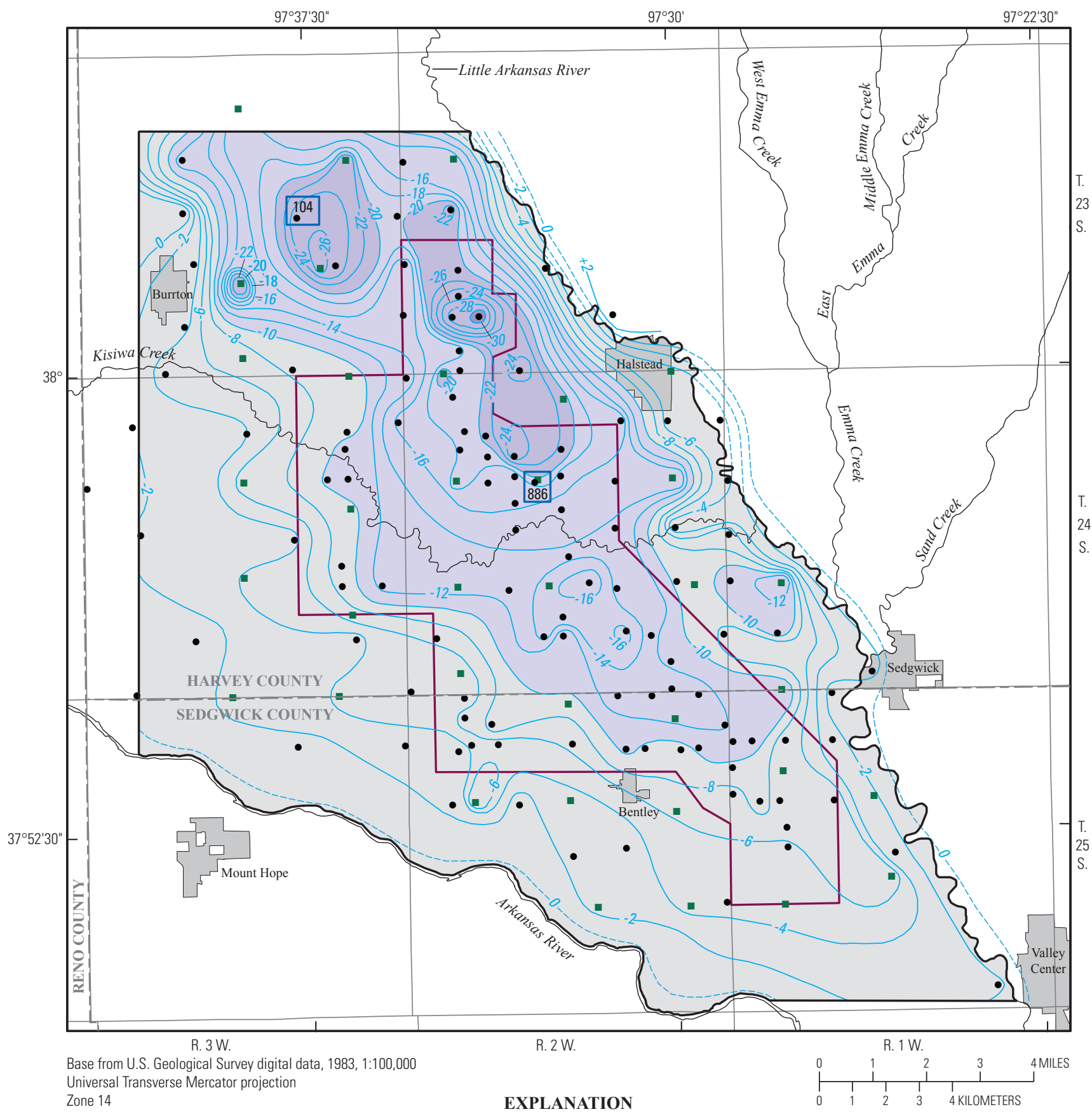

Universal Transverse Mercator projection

EXPLANATION

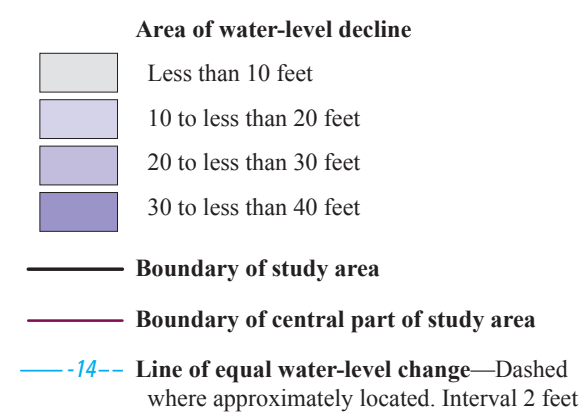

104 Well hydrograph shown in figure 2

- Equus Beds historic observation well

- Equus Beds areal index well

Water-level measurements were made by city of Wichita and Equus Beds Groundwater Management District No. 2 personnel.

Depletion of storage volume in study area between August 1940 and July 2006 is 180,000 acre-feet

Figure 9. Water-level changes in the Equus Beds aquifer in the study area, August 1940 to July 2006. 


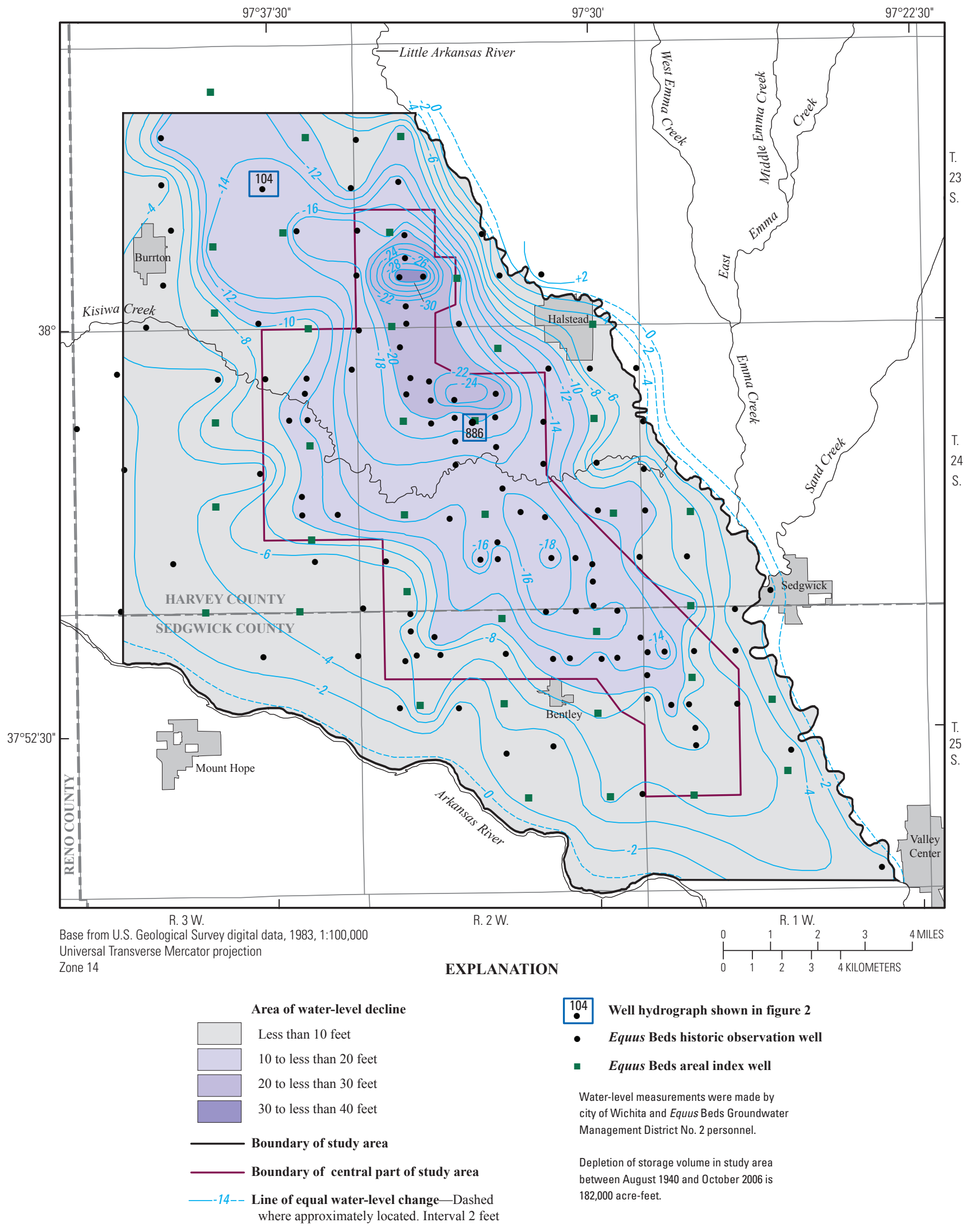

Figure 10. Water-level changes in the Equus Beds aquifer in the study area, August 1940 to October 2006. 

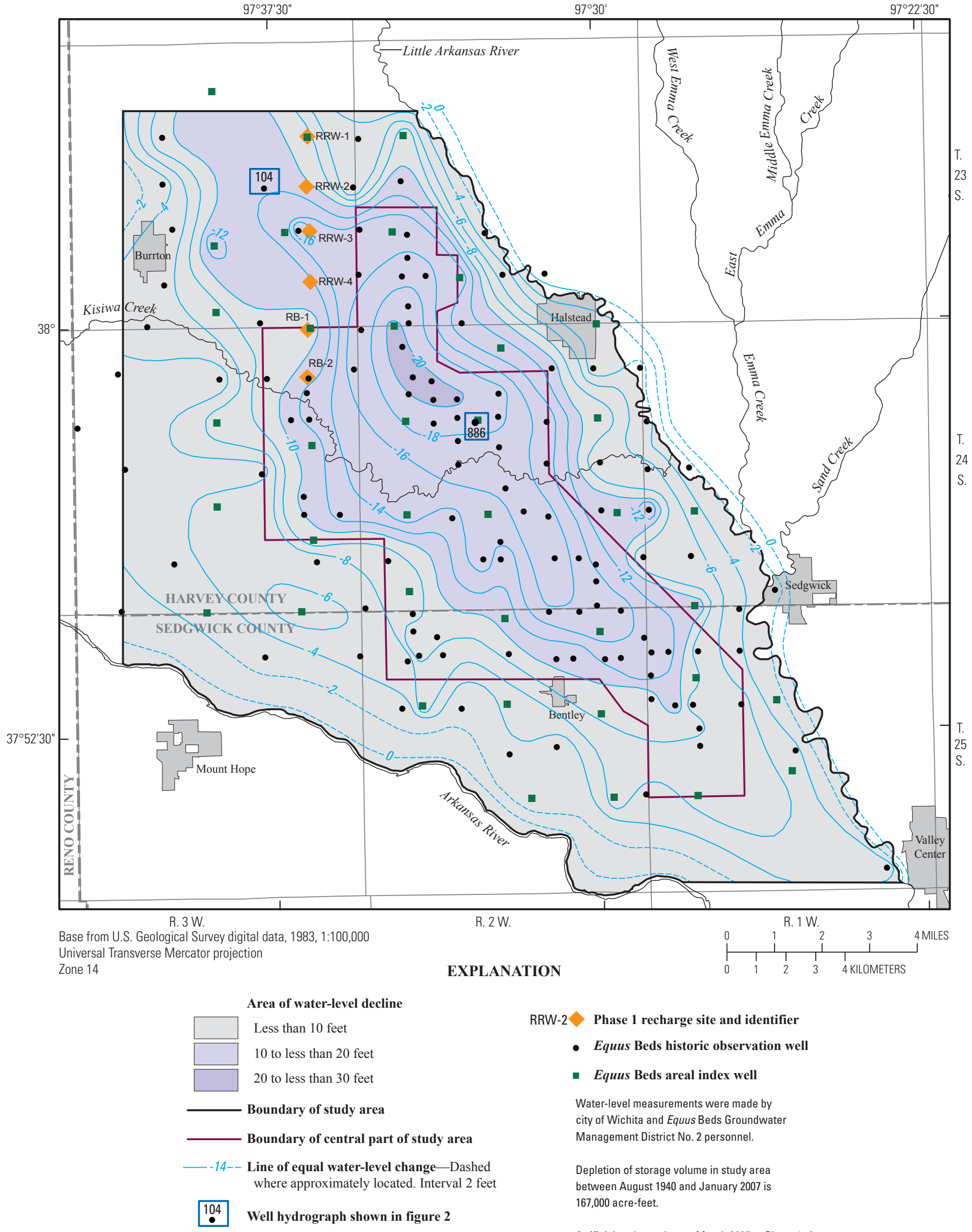

RRW-2 Phase 1 recharge site and identifier

- Equus Beds historic observation well

- Equus Beds areal index well

Water-level measurements were made by city of Wichita and Equus Beds Groundwater Management District No. 2 personnel.

Depletion of storage volume in study area between August 1940 and January 2007 is 167,000 acre-feet.

Artificial recharge began March 2007 at Phase 1 sites.

Figure 11. Water-level changes in the Equus Beds aquifer in the study area, August 1940 to January 2007. 


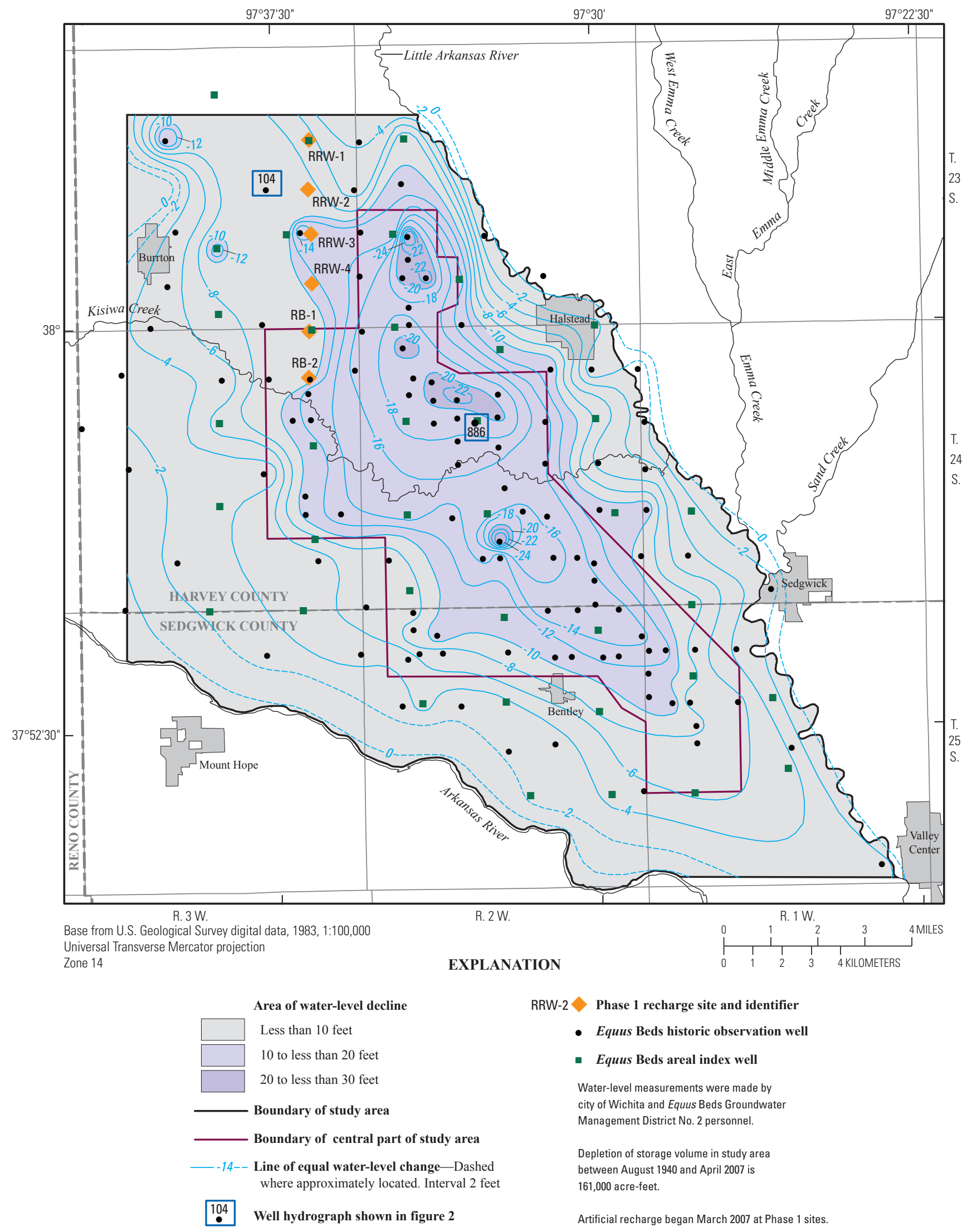

Figure 12. Water-level changes in the Equus Beds aquifer in the study area, August 1940 to April 2007. 


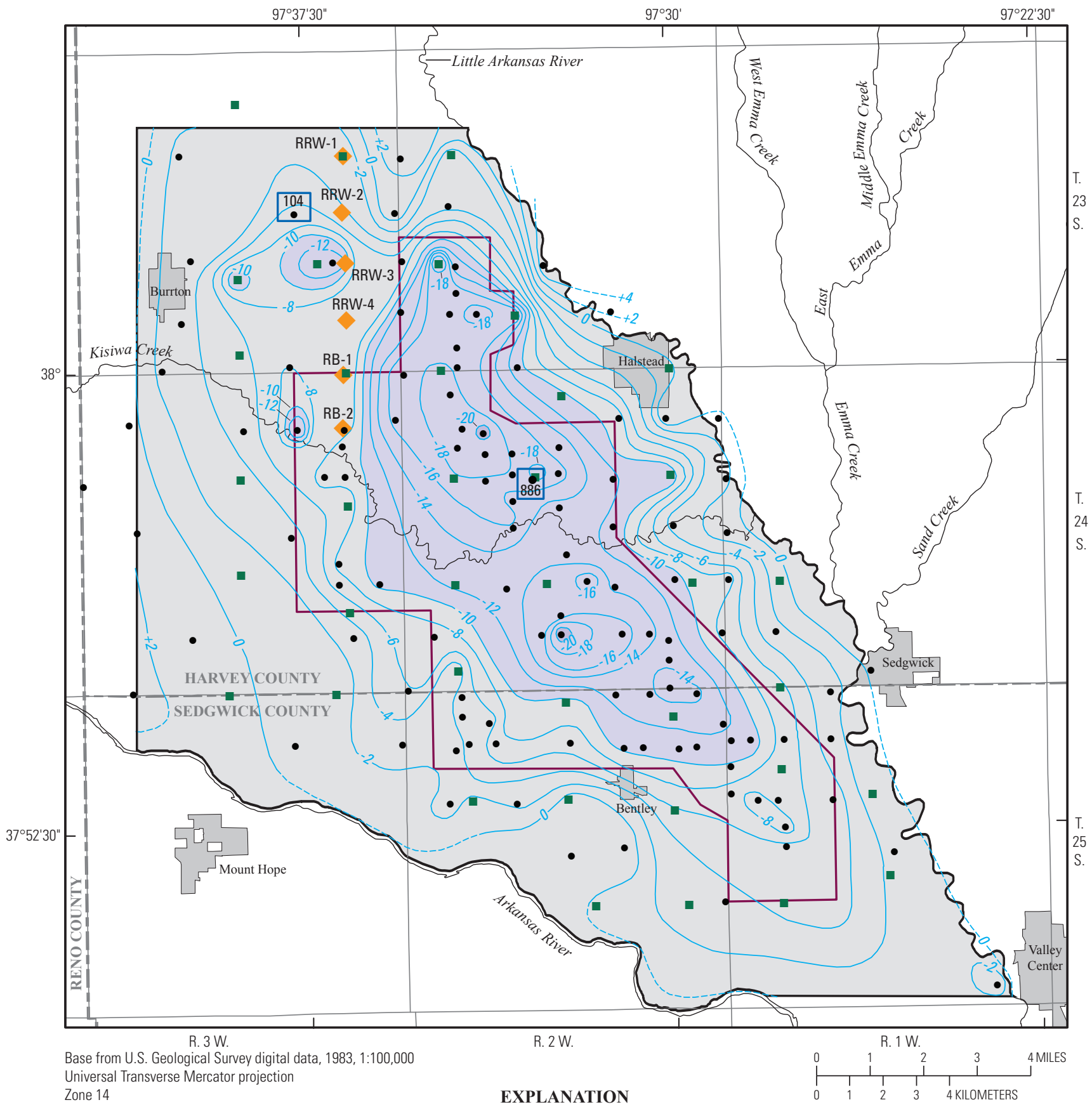

Universal Transverse Mercator projection

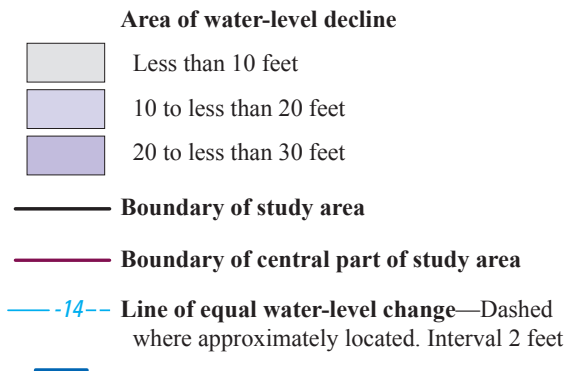

104 Well hydrograph shown in figure 2
RRW-2 Phase 1 recharge site and identifier

- Equus Beds historic observation well

- Equus Beds areal index well

Water-level measurements were made by city of Wichita and Equus Beds Groundwater Management District No. 2 personnel.

Depletion of storage volume in study area between August 1940 and July 2007 is 123,000 acre-feet

Artificial recharge began March 2007 at Phase 1 sites

Figure 13. Water-level changes in the Equus Beds aquifer in the study area, August 1940 to July 2007. 


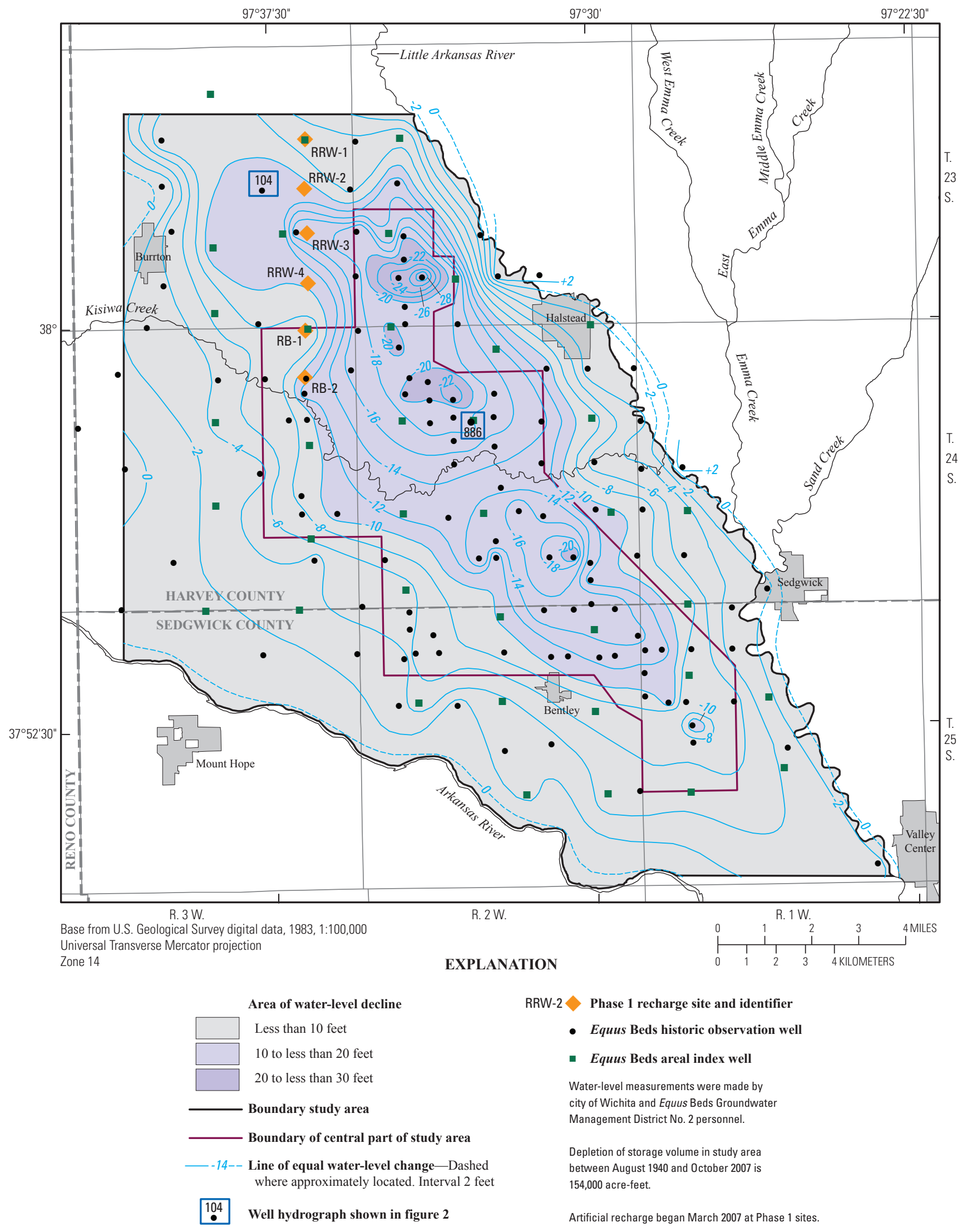

Figure 14. Water-level changes in the Equus Beds aquifer in the study area, August 1940 to October 2007. 


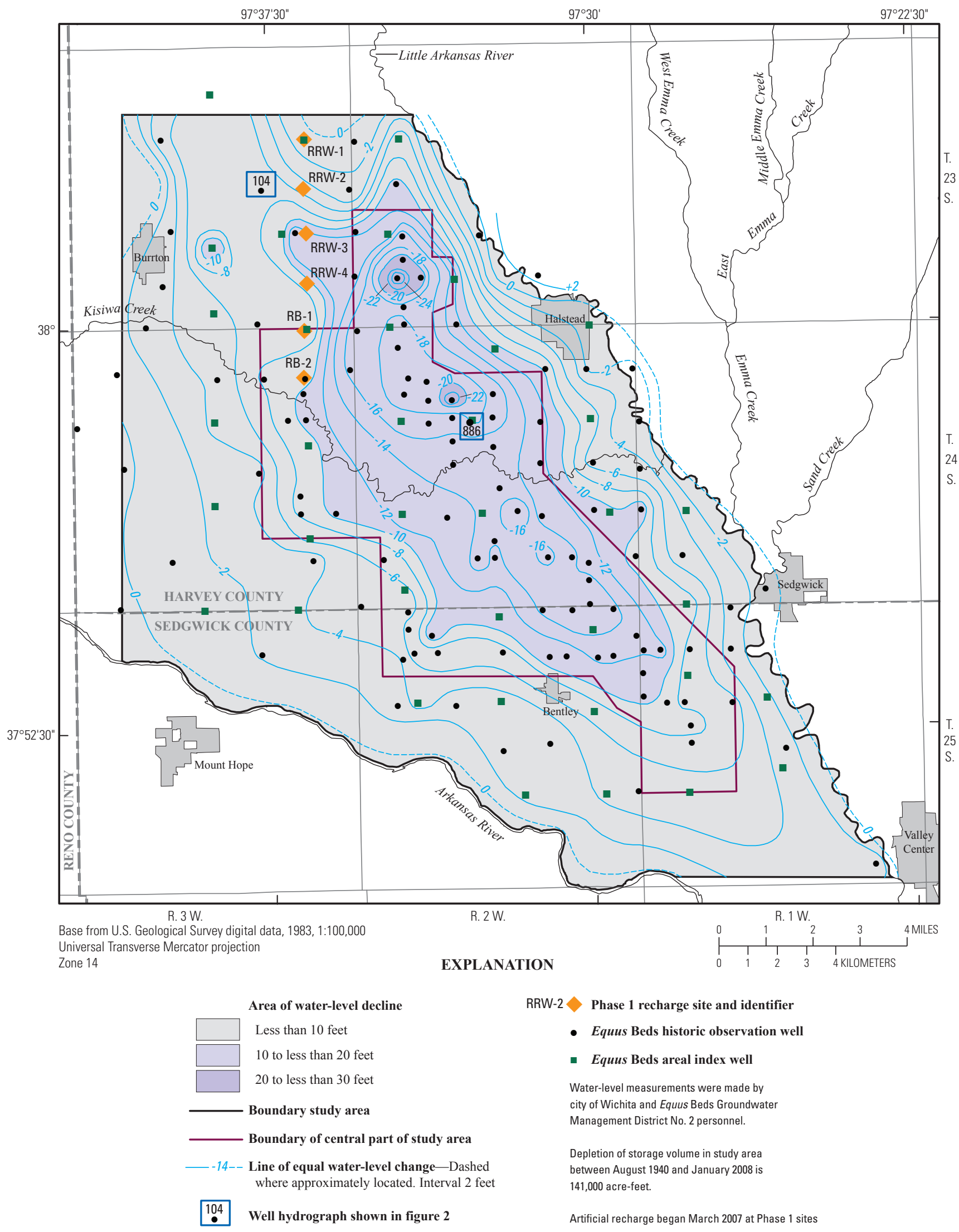

Figure 15. Water-level changes in the Equus Beds aquifer in the study area, August 1940 to January 2008. 


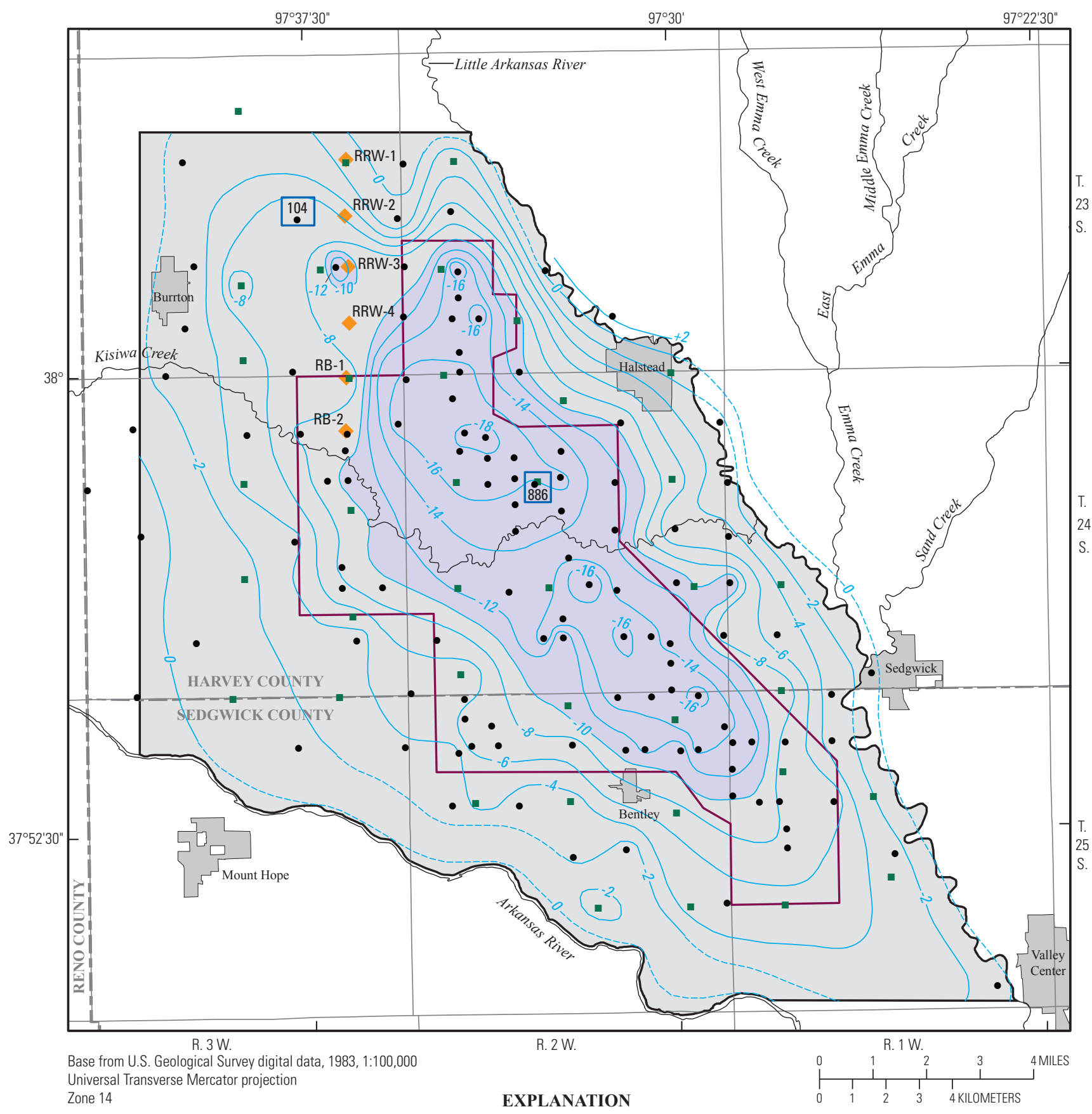

EXPLANATION

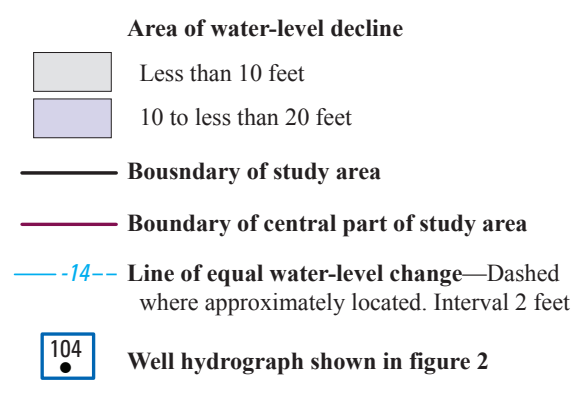

RRW-2 Phase 1 recharge site and identifier

- Equus Beds historic observation well

- Equus Beds areal index well

Water-level measurements were made by city of Wichita and Equus Beds Groundwater Management District No. 2 personnel.

Depletion of storage volume in study area between August 1940 and April 2008 is 135,000 acre-feet.

Artificial recharge began March 2007 at Phase 1 sites.

Figure 16. Water-level changes in the Equus Beds aquifer in the study area, August 1940 to April 2008. 


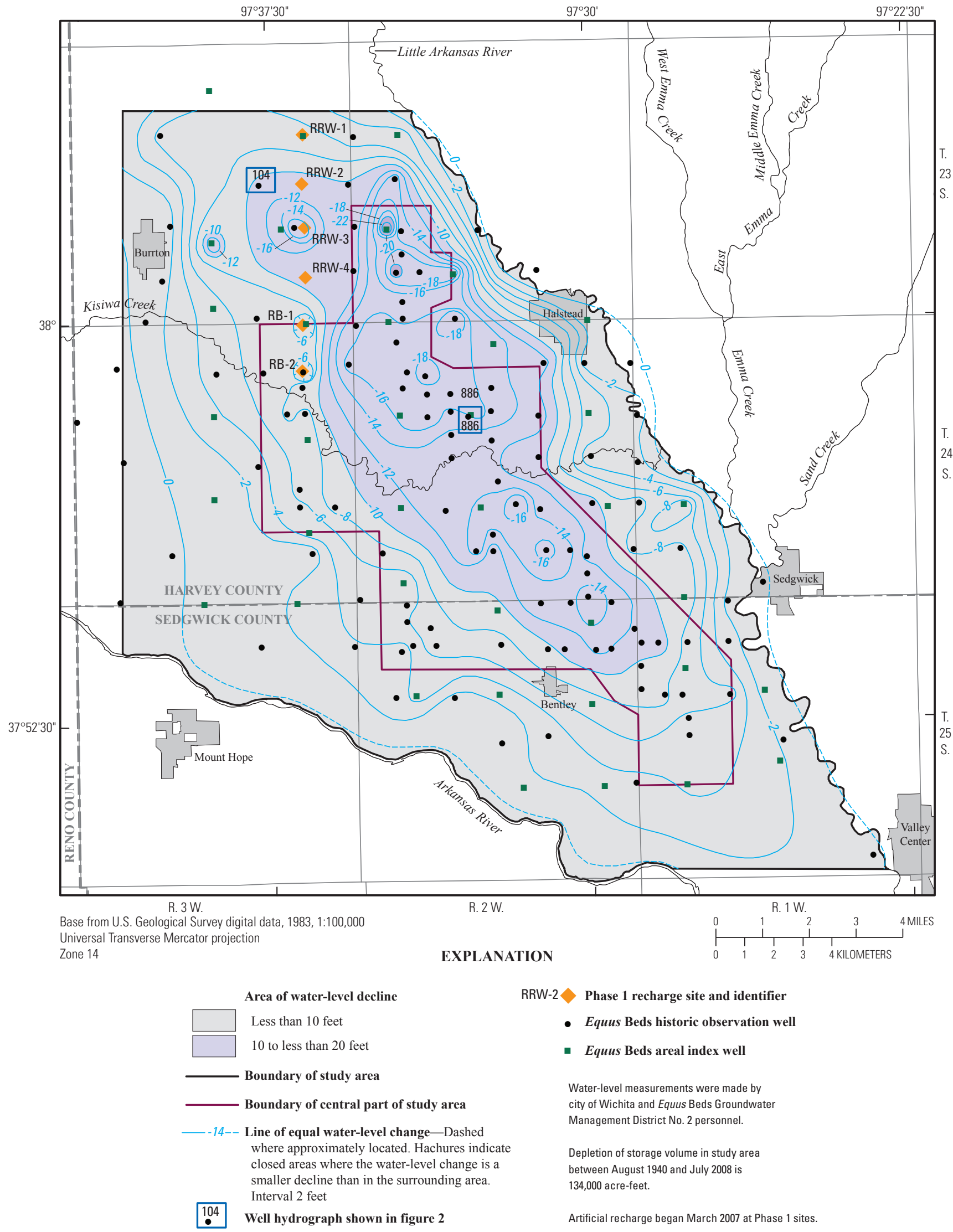

Figure 17. Water-level changes in the Equus Beds aquifer in the study area, August 1940 to July 2008. 


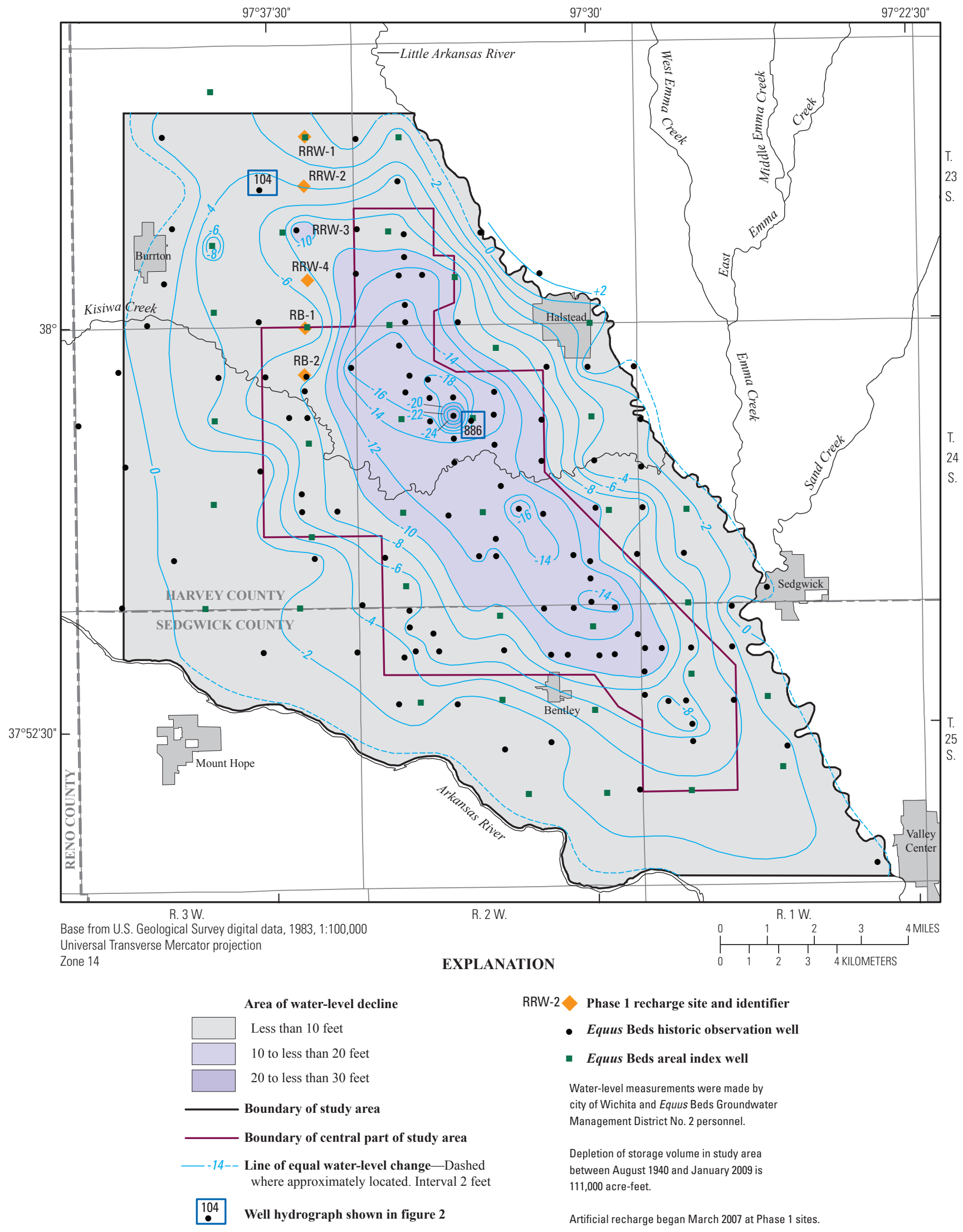

Figure 18. Water-level changes in the Equus Beds aquifer in the study area, August 1940 to January 2009. 


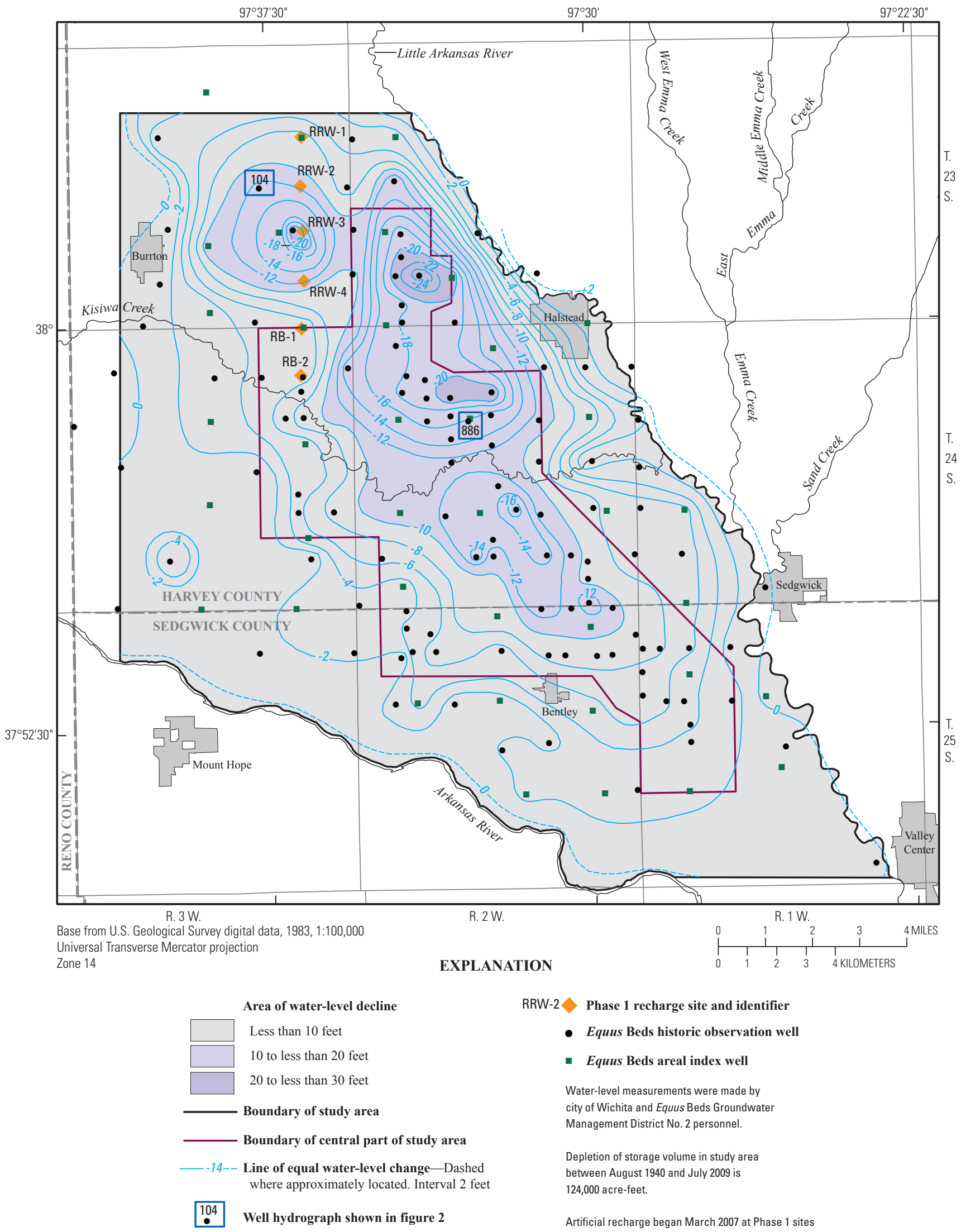

Figure 19. Water-level changes in the Equus Beds aquifer in the study area, August 1940 to July 2009. 


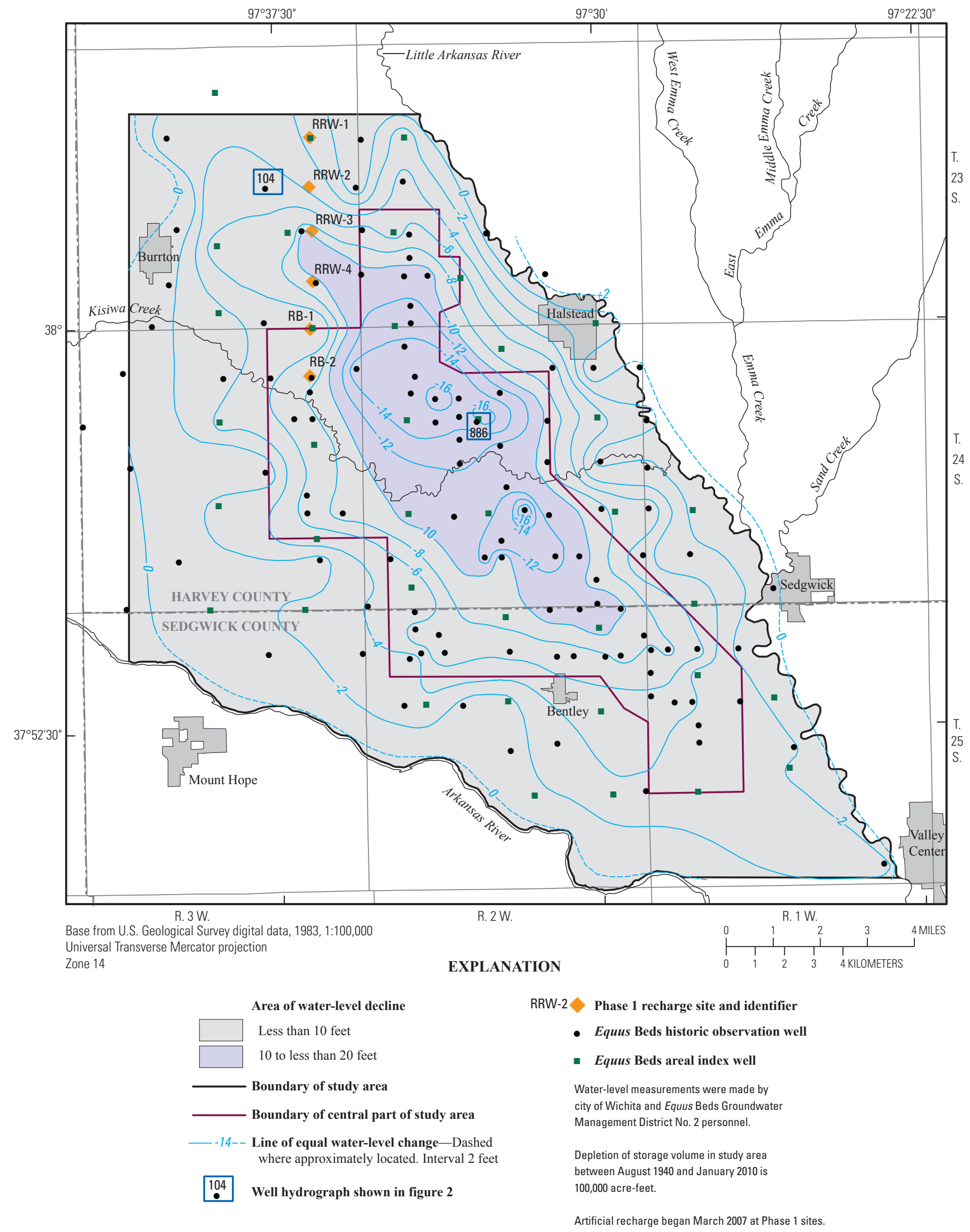

Figure 20. Water-level changes in the Equus Beds aquifer in the study area, August 1940 to January 2010. 
the summer months, so does irrigation and city pumpage, resulting in water-level rises that generally continue into the following spring. The maps of water-level changes since August 1940 for the period January 2006 to January 2010 show these water-level rises most obviously as the decrease in the size of the areas with declines of $10 \mathrm{ft}$ or more in the January and April maps and the complete disappearance of areas of declines of $20 \mathrm{ft}$ or more in January 2006 and April 2008 (figs. $7,8,11,12,15,16,18$, and 20).

\section{Cumulative Change Since Period of Maximum Decline}

As pointed out previously by Hansen and Aucott (2001, 2004), the maximum recorded decline in the study area occurred in October 1992 (fig. 21); therefore, a map for the period October 1992 to January 2010 was constructed to illustrate the magnitude of cumulative water-level changes since the period of maximum decline (fig. 22). The cumulative water-level changes from October 1992 to January 2010 ranged from declines of less than $2 \mathrm{ft}$ near the Little Arkansas River between Halstead and Kisiwa Creek and near Valley Center to rises of more than $30 \mathrm{ft}$ in two wells near the center of city pumpage in the central part of the study area (fig. 22). Seasonal water-level changes in some wells during October 1992 to January 2010 were larger than the cumulative waterlevel changes for the same period (for example, see hydrograph of observation well 104 in fig. 2C). For the October 1992 to January 2010 period, a large area of cumulative waterlevel rises of $10 \mathrm{ft}$ or more occurred throughout much of the study area, and a large area of rises of $20 \mathrm{ft}$ or more occurred in the northern and center parts of the study area and in a small area in T. 25 S., R. 2 W. (fig. 22). Almost all the wells in the study area had cumulative water-level rises from October 1992 to January 2010 (fig. 22). The average cumulative water-level change in the study area from October 1992 to January 2010 was a rise of about $8.7 \mathrm{ft}$.

Recharge from precipitation contributed to the overall water-level rises seen throughout the study area (fig. 22) from October 1992 to January 2010 because annual precipitation during 1993-2009 averaged about 2 in. greater than the longterm (1940-2009) annual average precipitation of $31.52 \mathrm{in.}$ (fig. 2A). Decreased city pumpage during 1993-2009 (fig 2B) contributed to the water-level rises of $10 \mathrm{ft}$ or more between October 1992 and January 2010 that occurred throughout most of the central part of the study area and extended beyond to the northwest and east (fig. 22). During 1993-2009, city pumpage from the Equus Beds aquifer, which occurs primarily in the central part of the study area, decreased by about one-half from about 38,600 to 19,700 acre-ft or from about 60 percent to about 32 percent of Wichita's usage (fig. $2 B$ ). Some of the city wells in the northern part of the central part of the study area were not pumped in late 2009 because of a pipeline break (Richard Robinson, written commun., city of Wichita, March 18, 2010), which contributed in part to the water-level rises seen in this area. An important factor in the decreased city pumpage from the aquifer was increased use of Cheney Reservoir by the city of Wichita as a water-supply source. Changes in irrigation pumpage did not contribute to the overall rise from October 1992 to January 2010 because irrigation pumpage increased from about 22,500 acre-ft in 1993 to about 25,200 acre-ft in 2009 and was as much or more during most of the intervening years (fig. $2 B$ ). Irrigation pumpage varied considerably from year to year because of climatic variations, so reduced irrigation pumpage could contribute to rises in some years. Artificial recharge of about 3,300 acre-ft occurred during 1997-2002 at the Equus Beds Recharge Demonstration Project sites (fig. 1) and about 2,600 acre-ft during 2007-09 at the Phase 1 recharge sites for a total of about 5,900 acre-ft (fig. 2B). This small amount of artificial recharge relative to irrigation and city pumpage also contributed to the water level rises, but principally in the vicinity of the recharge sites. A numerical groundwater-flow model can provide a more definitive accounting of the causes of these water-level rises.

\section{Cumulative Change Since Beginning of Large- Scale Artificial Recharge}

The Equus Beds ASR project began large-scale artificial recharge at the six Phase 1 recharge sites (fig. 23) in March 2007. The January 2007 water-level measurements made in the Equus Beds historic observation and areal index wells were the last set before the beginning of Phase 1 recharge. Therefore, a map of water-level changes from January 2007 to January 2010 would be expected to show the cumulative effects of large-scale artificial recharge in addition to the other hydrologic factors that changed between those times (fig. 23). This map shows almost all wells in the study area experienced small cumulative water-level rises since the beginning Phase 1 recharge (fig. 23). Cumulative water-level changes from January 2007 to January 2010 ranged from a decline of less than $2 \mathrm{ft}$ at a well about $2 \mathrm{mi}$ west of artificial recharge site RB-2 to rises of more than $8 \mathrm{ft}$ in the northern part of the study area (fig. 23). The cumulative water-level changes from January 2007 to January 2010 commonly were rises of more than $4 \mathrm{ft}$ in the northern and central parts of the study area and rises of less than $4 \mathrm{ft}$ in the rest of the study area (fig. 23). The average cumulative water-level change in the study area from January 2007 to January 2010 was about $3.2 \mathrm{ft}$.

Recharge from precipitation during 2007-09 contributed to the overall rises seen throughout the study area because precipitation averaged about 6 in/yr greater than the long-term annual average (fig. $2 A$ ). Decreased city pumpage, which went from about 20,800 acre-ft in 2007 to about 19,700 acre-ft in 2009 , contributed to the rises in and near the central part of the study area. The large rises of $10 \mathrm{ft}$ or more seen in T. $23 \mathrm{~S}$., R. $2 \mathrm{~W}$. in the central part of the study area probably are because a pipeline break prevented most of the city wells in this area from being used in late 2009 (Richard Robinson, written commun., city of Wichita, March 18, 2010). Irrigation pumpage 


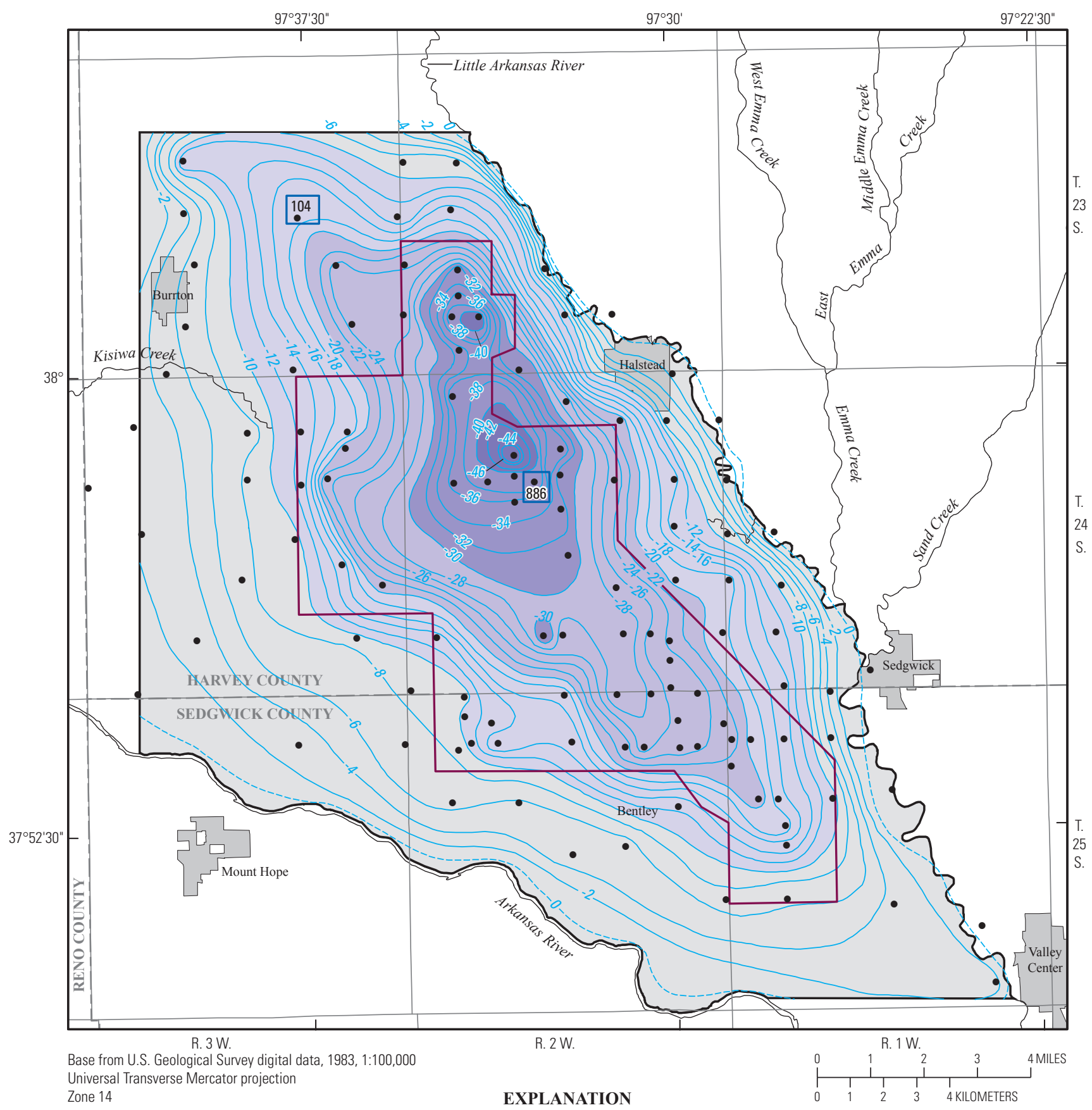

104
-

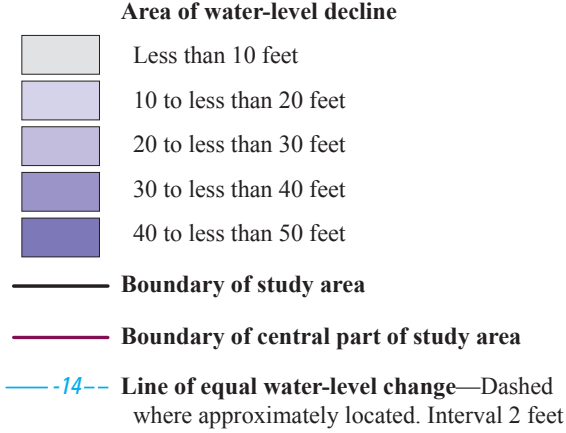

- $\quad$ Equus Beds historic observation well

Water-level measurements were made by city of Wichita personnel.

Depletion of storage volume in study area between August 1940 and October 1992 is 283,000 acre-feet.

Figure 21. Water-level changes in the Equus Beds aquifer in the study area, August 1940 to October 1992 (modified from Aucott and Hansen, 2001). 


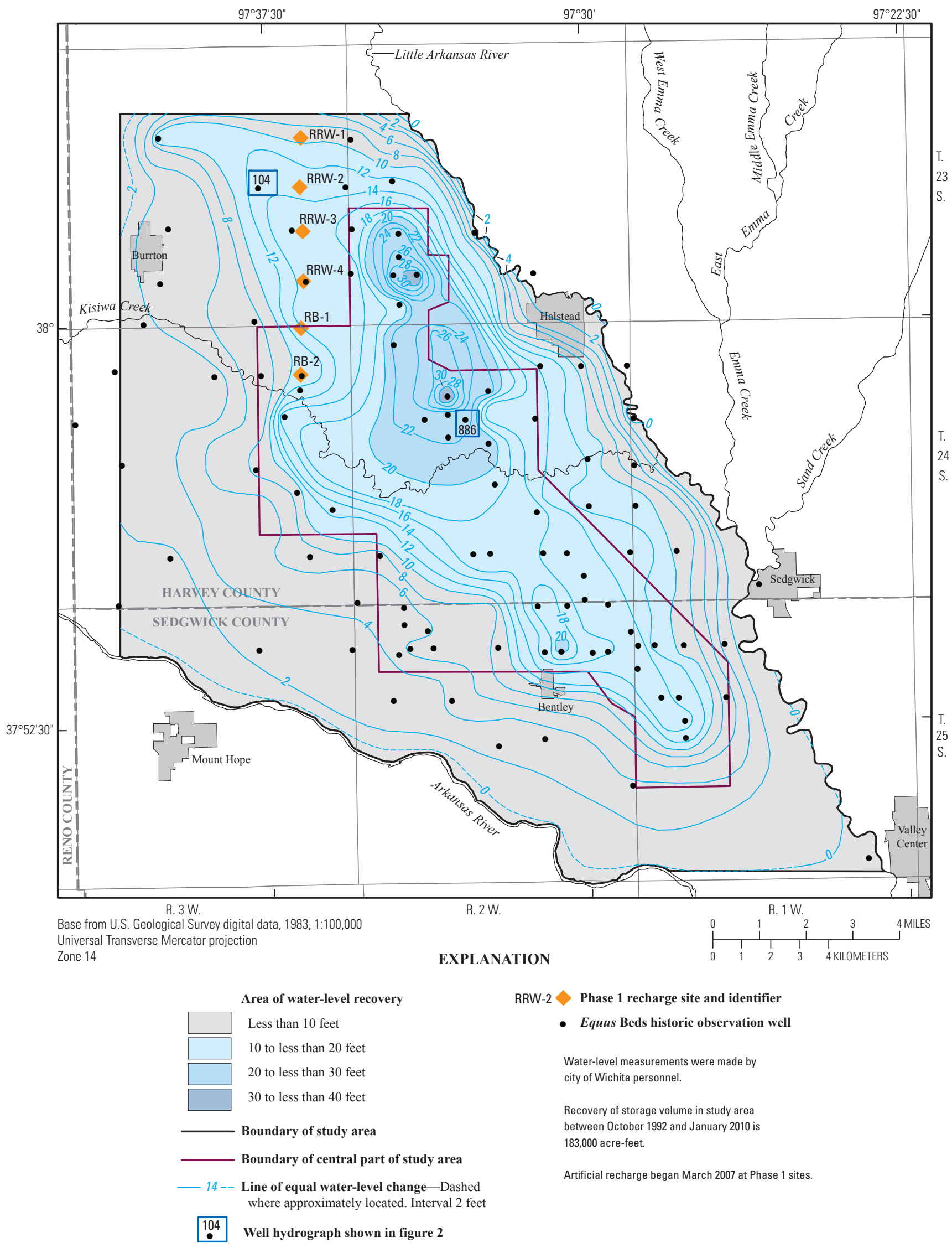

Figure 22. Water-level changes in the Equus Beds aquifer in the study area, October 1992 to January 2010. 


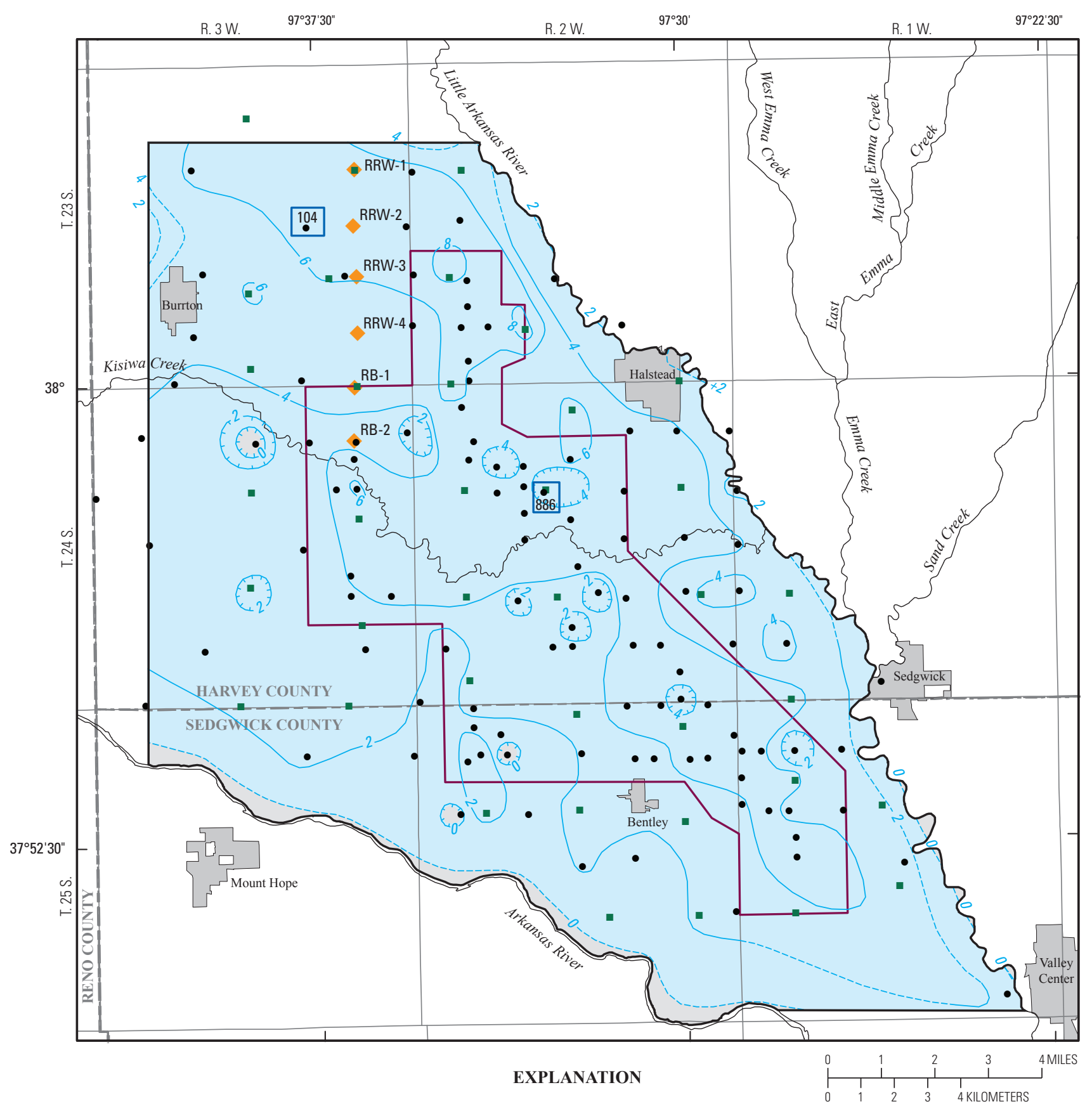

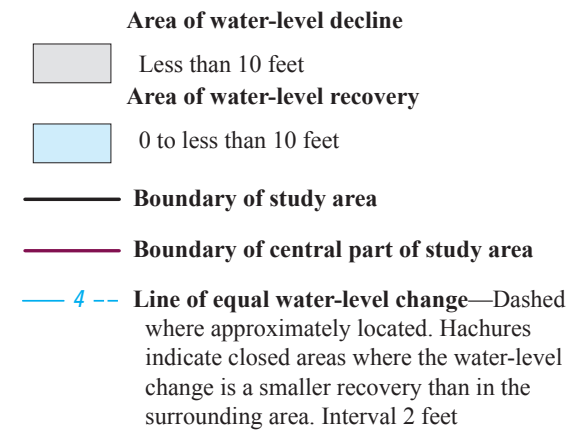

$104 \quad$ Well hydrograph shown in figure 2

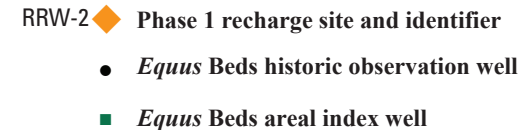

Water-level measurements were made by city of Wichita and Equus Beds Groundwater Management District No. 2 personnel.

Recovery of storage volume in study area between January 2007 and January 2010 is 67,000 acre-feet.

Artificial recharge began March 2007 at Phase 1 sites.

Figure 23. Water-level changes in the Equus Beds aquifer in the study area, January 2007 to January 2010. 
decreased from about 26,900 acre-ft in 2007 to about 25,200 acre-ft in 2009 and contributed in part to the water-level rises during this period. The artificial recharge of about 2,600 acre$\mathrm{ft}$ that occurred at the Phase 1 recharge sites during 2007-09 also contributed to the 2007-09 water-level rises, but principally near the Phase 1 recharge sites.

\section{Storage-Volume Changes}

Storage-volume change is defined for the purposes of this report as the change in saturated aquifer volume multiplied by the specific yield of the aquifer. A specific yield of 0.2 has been used to compute the storage-volume change in the Equus Beds aquifer since Stramel (1956) first computed storage volume for the aquifer and is retained for this report as described in the Specific Yield section. The changes in storage volume since August 1940 for the selected time periods shown in table 1 were computed using computer-generated Thiessen polygons (Thiessen, 1911) that were based on the measured water-level changes at wells and the manually drawn lines of equal water-level change (figs. 7-20).

Storage-volume change for a period beginning at a time other than August 1940 (table 1) was calculated as the difference between storage-volume changes for August 1940 to the beginning of the selected time period and for August 1940 to the end of the selected time period. For example, the storagevolume change for January 2007 to January 2010 (table 1) was calculated as the difference between the storage-volume change for August 1940 to January 2007 and for August 1940 to January 2010. The storage-volume changes since predevelopment (August 1940), since the period of maximum decline (October 1992), and since the beginning of the period of largescale artificial recharge (January 2007) are shown in table 1 for the study area and the central part of the study area. The storage-volume changes since October 1992 as a percentage of the storage volume lost between August 1940 and October 1992 are included in table 1 for both areas. Also included in table 1 are storage-volume changes since January 1993, the period of low water levels cited by the Equus Beds ASR Phase 1 permit (Approval of Application to Appropriate Water Application File Nos. 45567 through 45571, 45576, 46081, and 46578, Kansas Department of Agriculture, Division of Water Resources, Topeka, Kansas, August 8, 2005, and February 19, 2007). The storage-volume changes for the study area since August 1940 are shown graphically in figure $2 C$ and figure 24 for selected periods.

Following the maximum loss of storage that occurred from August 1940 to October 1992 in the study area (Hansen and Aucott, 2001), storage volume in the study area generally has continued to recover through January 2010 with some loss of recovery during years with less than average precipitation (for example, in 2003 and 2006) and subsequent to summer months where heavier pumping occurs (fig. $2 A$ and $2 C$ ). Changes in storage volumes from August 1940 to January
2010 in the study area and in the central part of the study area were $-100,000$ and $-57,600$ acre-ft, respectively (table 1). Water levels and storage volumes in January 2010 were similar to those seen in the late 1970s and early 1950s (fig. 2C).

\section{Cumulative Change Since Period of Maximum Decline}

The storage-volume change in the study area for the period October 1992 to January 2010 represents a recovery of about 183,000 acre-ft or about 65 percent of storage previously lost between August 1940 and October 1992 in the study area (table 1). The storage-volume change in the central part of the study area for October 1992 to January 2010 represents about 101,400 acre-ft or about a 64-percent recovery of storage lost between August 1940 and October 1992 in this part of the study area (table 1). These are the largest post-October 1992 recoveries to date in the study area and the central part of the study area (table 1).

The change since 1993 of the components of irrigation and city pumpage and artificial recharge (table 2) can be totaled for a cumulative change for each component; these cumulative changes can be used for a comparison of the relative importance of these components during the 1993-2009 period. These cumulative changes are an increase of about 128,100 acre-ft for irrigation pumpage, a decrease of about 256,500 acre-ft for city pumpage; and an increase of about 5,900 acre- $\mathrm{ft}$ for artificial recharge. Irrigation pumpage, because it increased, did not contribute to the recovery of storage volume from October 1992 to January 2010. Artificial recharge and the decrease in city pumpage contributed to the recovery of storage volume, but artificial recharge's contribution was more than an order of magnitude less. Recharge from excess precipitation contributed to the recovery of storage volume in this period because precipitation averaged about $2 \mathrm{in} / \mathrm{yr}$ more than the annual long-term average of $31.52 \mathrm{in.}$ (fig2 $A$, table 2).

\section{Cumulative Change Since Beginning of Large- Scale Artificial Recharge}

The storage-volume change since the beginning of largescale artificial recharge (January 2007 to January 2010) of 67,000 acre-ft in the study area represents a recovery of about 40 percent of the storage volume lost between August 1940 and January 2007 (table1). In the central part of the study area, the storage-volume change for this period is about 25,300 acre-ft or about a 31-percent recovery of the storage-volume previously lost between August 1940 and January 2007 (table 1).

Decreases in irrigation and city pumpage and artificial recharge of about 2,600 acre-ft during 2007-09 contributed to the recovery of storage volume during this period. Recharge from precipitation also contributed to the recovery because 
Table 1. Storage-volume changes in Equus Beds aquifer near Wichita, south-central Kansas, August 1940 to January 2010.

[Data on file with U.S. Geological Survey, Lawrence, Kansas; --, not applicable; NA, not available]

\begin{tabular}{|c|c|c|c|c|c|c|c|}
\hline $\begin{array}{l}\text { End date of } \\
\text { time period }\end{array}$ & $\begin{array}{c}\text { Since } \\
\text { August } 1940 \\
\text { (acre-feet) }\end{array}$ & $\begin{array}{c}\text { Since } \\
\text { October } 1992 \\
\text { (acre-feet) }\end{array}$ & $\begin{array}{c}\text { Since } \\
\text { October } 1992 \\
\text { (percent) }\end{array}$ & $\begin{array}{c}\text { Since } \\
\text { January } 1993 \\
\text { (acre-feet) }\end{array}$ & $\begin{array}{c}\text { Since } \\
\text { January } 2006 \\
\text { (acre-feet) }\end{array}$ & $\begin{array}{c}\text { Since } \\
\text { January } 2007 \\
\text { (acre-feet) }\end{array}$ & $\begin{array}{c}\text { Since } \\
\text { January } 2007 \\
\text { (percent) }\end{array}$ \\
\hline January 1989 & $-209,000$ & -- & -- & -- & -- & -- & -- \\
\hline January 1990 & NA & -- & -- & -- & -- & -- & -- \\
\hline October 1992 & ${ }^{1}-283,000$ & -- & -- & -- & -- & -- & -- \\
\hline January 1993 & ${ }^{2}-255,000$ & ${ }^{5}+28,000$ & ${ }^{5}+10$ & -- & -- & -- & -- \\
\hline January 1997 & ${ }^{3}-205,000$ & $+78,000$ & +28 & $+50,000$ & -- & -- & -- \\
\hline January 1998 & ${ }^{2}-176,000$ & $+107,000$ & +38 & ${ }^{2}+79,000$ & -- & -- & -- \\
\hline January 1999 & ${ }^{1}-142,000$ & $+141,000$ & +50 & $+113,000$ & -- & -- & -- \\
\hline January 2000 & ${ }^{1}-126,000$ & ${ }^{4}+157,000$ & +55 & $+129,000$ & -- & -- & -- \\
\hline January 2001 & ${ }^{4}-134,000$ & $+149,000$ & +53 & $+121,000$ & -- & -- & -- \\
\hline January 2002 & ${ }^{4}-142,000$ & $+141,000$ & +50 & $+113,000$ & -- & -- & -- \\
\hline January 2003 & ${ }^{4}-159,000$ & ${ }^{4}+124,000$ & $5+44$ & $+96,000$ & -- & -- & -- \\
\hline April 2004 & $5-147,000$ & ${ }^{5}+136,000$ & $5+48$ & $+108,000$ & -- & -- & -- \\
\hline July 2004 & ${ }^{5}-166,000$ & ${ }^{5}+117,000$ & $5+41$ & $+89,000$ & -- & -- & -- \\
\hline October 2004 & ${ }^{5}-158,000$ & ${ }^{5}+125,000$ & $5+44$ & $+97,000$ & -- & -- & -- \\
\hline January 2005 & ${ }^{5}-143,000$ & $5+140,000$ & $5+49$ & $+112,000$ & -- & -- & -- \\
\hline April 2005 & ${ }^{5}-131,000$ & ${ }^{5}+152,000$ & ${ }^{5}+54$ & $+124,000$ & -- & -- & -- \\
\hline July 2005 & ${ }^{5}-137,000$ & ${ }^{5}+146,000$ & $5+52$ & $+118,000$ & -- & -- & -- \\
\hline October 2005 & ${ }^{5}-131,000$ & ${ }^{5}+152,000$ & $5+54$ & $+124,000$ & -- & -- & -- \\
\hline January 2006 & ${ }^{5}-127,000$ & ${ }^{5}+156,000$ & $5+55$ & $+128,000$ & -- & -- & -- \\
\hline April 2006 & $-135,000$ & $+148,000$ & +52 & $+120,000$ & $-8,000$ & -- & -- \\
\hline July 2006 & $-180,000$ & $+103,000$ & +36 & $+75,000$ & $-53,000$ & -- & -- \\
\hline October 2006 & $-182,000$ & $+101,000$ & +36 & $+73,000$ & $-55,000$ & -- & -- \\
\hline
\end{tabular}


Table 1. Storage-volume changes in Equus Beds aquifer near Wichita, south-central Kansas, August 1940 to January 2010.Continued

[Data on file with U.S. Geological Survey, Lawrence, Kansas; --, not applicable; NA, not available]

\begin{tabular}{|c|c|c|c|c|c|c|c|}
\hline $\begin{array}{l}\text { End date of } \\
\text { time period }\end{array}$ & $\begin{array}{c}\text { Since } \\
\text { August } 1940 \\
\text { (acre-feet) }\end{array}$ & $\begin{array}{c}\text { Since } \\
\text { October } 1992 \\
\text { (acre-feet) }\end{array}$ & $\begin{array}{c}\text { Since } \\
\text { October } 1992 \\
\text { (percent) }\end{array}$ & $\begin{array}{c}\text { Since } \\
\text { January } 1993 \\
\text { (acre-feet) }\end{array}$ & $\begin{array}{c}\text { Since } \\
\text { January } 2006 \\
\text { (acre-feet) }\end{array}$ & $\begin{array}{c}\text { Since } \\
\text { January } 2007 \\
\text { (acre-feet) }\end{array}$ & $\begin{array}{c}\text { Since } \\
\text { January } 2007 \\
\text { (percent) }\end{array}$ \\
\hline \multicolumn{8}{|c|}{ Change in storage volume in the study area-Continued } \\
\hline January 2007 & $-167,000$ & $+116,000$ & +41 & $+88,000$ & $-40,000$ & -- & -- \\
\hline April 2007 & $-161,000$ & $+122,000$ & +43 & $+94,000$ & $-34,000$ & $+6,000$ & +6 \\
\hline July 2007 & $-123,000$ & $+160,000$ & +57 & $+132,000$ & $+4,000$ & $+44,000$ & +26 \\
\hline October 2007 & $-154,000$ & $+129,000$ & +46 & $+101,000$ & $-27,000$ & $+13,000$ & +8 \\
\hline January 2008 & $-141,000$ & $+142,000$ & +50 & $+144,000$ & $-14,000$ & $+26,000$ & +16 \\
\hline April 2008 & $-135,000$ & $+148,000$ & +52 & $+120,000$ & $-8,000$ & $+32,000$ & +19 \\
\hline July 2008 & ${ }^{6}-134,000$ & $+149,000$ & +53 & $+121,000$ & $-7,000$ & $+33,000$ & +20 \\
\hline January 2009 & ${ }^{7}-111,000$ & $+172,000$ & +61 & $+144,000$ & $+16,000$ & $+56,000$ & +34 \\
\hline July 2009 & $-124,000$ & $+159,000$ & +56 & $+131,000$ & $+3,000$ & $+43,000$ & +26 \\
\hline January 2010 & $-100,000$ & $+183,000$ & +65 & $+155,000$ & $+28,000$ & $+67,000$ & +40 \\
\hline \multicolumn{8}{|c|}{ Change in storage volume in the central part of the study area } \\
\hline January 1989 & NA & -- & -- & -- & -- & -- & -- \\
\hline January 1990 & NA & -- & -- & -- & -- & -- & -- \\
\hline January 1991 & NA & -- & -- & -- & -- & -- & -- \\
\hline January 1992 & NA & -- & -- & -- & -- & -- & -- \\
\hline October 1992 & ${ }^{1}-159,000$ & -- & -- & -- & -- & -- & -- \\
\hline January 1993 & ${ }^{2}-154,000$ & $5+5,000$ & $5+3$ & -- & -- & -- & -- \\
\hline January 1994 & $\mathrm{NA}$ & NA & NA & NA & -- & -- & -- \\
\hline January 1995 & NA & NA & NA & NA & -- & -- & -- \\
\hline January 1996 & $\mathrm{NA}$ & NA & NA & NA & -- & -- & -- \\
\hline January 1997 & ${ }^{3}-123,000$ & $+36,000$ & +23 & $+31,000$ & -- & -- & -- \\
\hline January 1998 & ${ }^{2}-110,000$ & $+49,000$ & +31 & ${ }^{2}+44,000$ & -- & -- & -- \\
\hline January 1999 & ${ }^{1}-96,300$ & $+62,700$ & +39 & $+57,700$ & -- & -- & -- \\
\hline January 2000 & $1-70,600$ & ${ }^{4}+88,400$ & $3+56$ & ${ }^{1}+83,400$ & -- & -- & -- \\
\hline January 2001 & ${ }^{4}-78,900$ & $+80,100$ & +50 & $+75,100$ & -- & -- & -- \\
\hline January 2002 & ${ }^{4}-77,100$ & $+81,900$ & +52 & $+76,900$ & -- & -- & -- \\
\hline January 2003 & ${ }^{4}-83,400$ & ${ }^{4}+75,600$ & +48 & $+70,600$ & -- & -- & -- \\
\hline April 2003 & $5-84,400$ & $5+74,600$ & $5+47$ & $+69,600$ & -- & -- & -- \\
\hline July 2003 & ${ }^{5}-89,300$ & ${ }^{5}+69,700$ & $5+44$ & $+64,700$ & -- & -- & -- \\
\hline October 2003 & $5-92,300$ & $5+66,700$ & ${ }^{5}+42$ & $+61,700$ & -- & -- & -- \\
\hline
\end{tabular}


Table 1. Storage-volume changes in Equus Beds aquifer near Wichita, south-central Kansas, August 1940 to January 2010. Continued

[Data on file with U.S. Geological Survey, Lawrence, Kansas; --, not applicable; NA, not available]

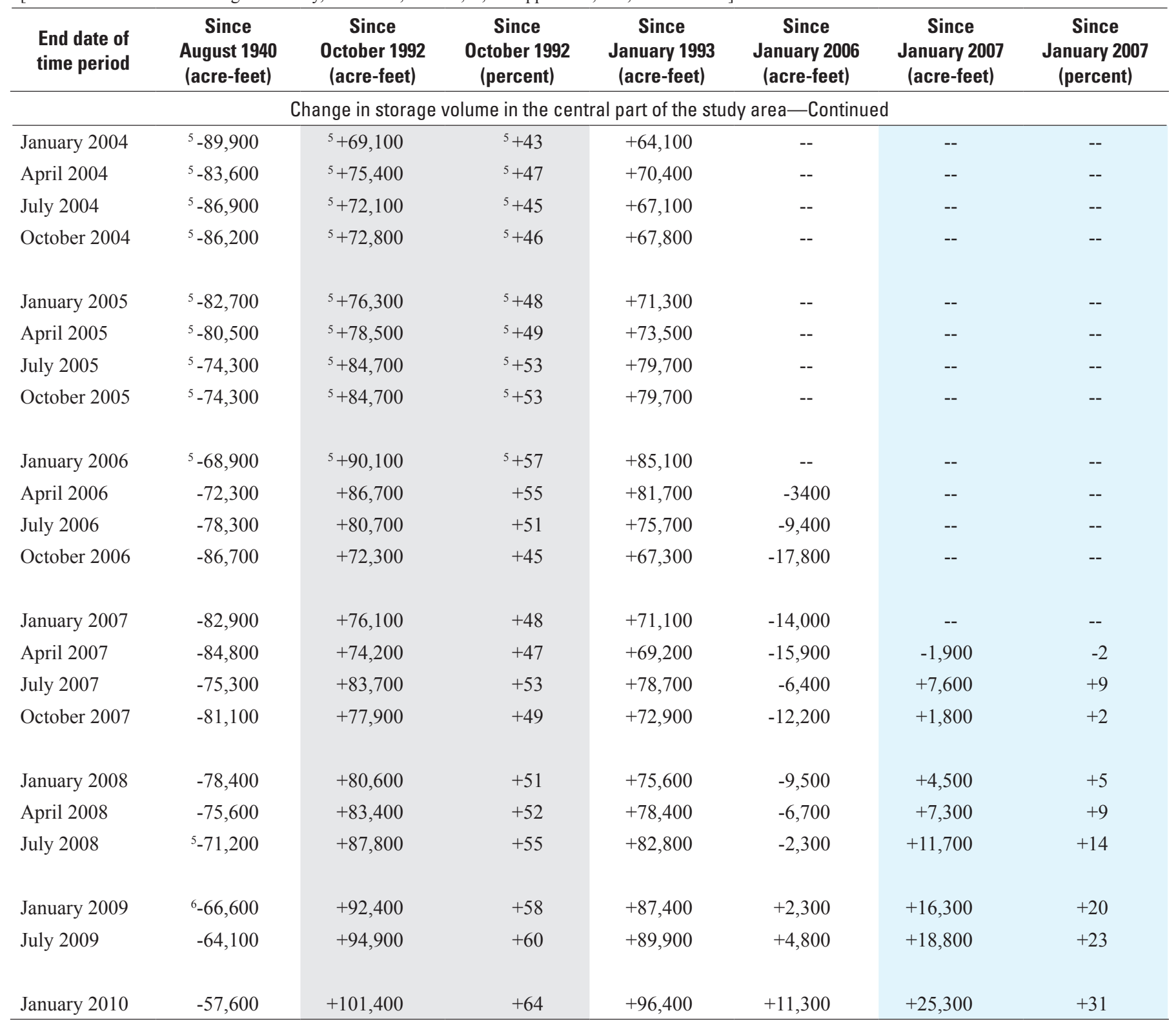

\footnotetext{
${ }^{1}$ Storage-volume change previously reported by Hansen and Aucott (2001).

${ }^{2}$ Storage-volume change previously reported by Aucott and Myers (1998).

${ }^{3}$ Storage-volume change previously reported by Aucott and others (1998).

${ }^{4}$ Storage-volume change previously reported by Hansen and Aucott (2004).

${ }^{5}$ Storage-volume change previously reported by Hansen (2007).

${ }^{6}$ Storage-volume change previously reported by Hansen (2009a).

${ }^{7}$ Storage-volume change previously reported by Hansen (2009b).
} 


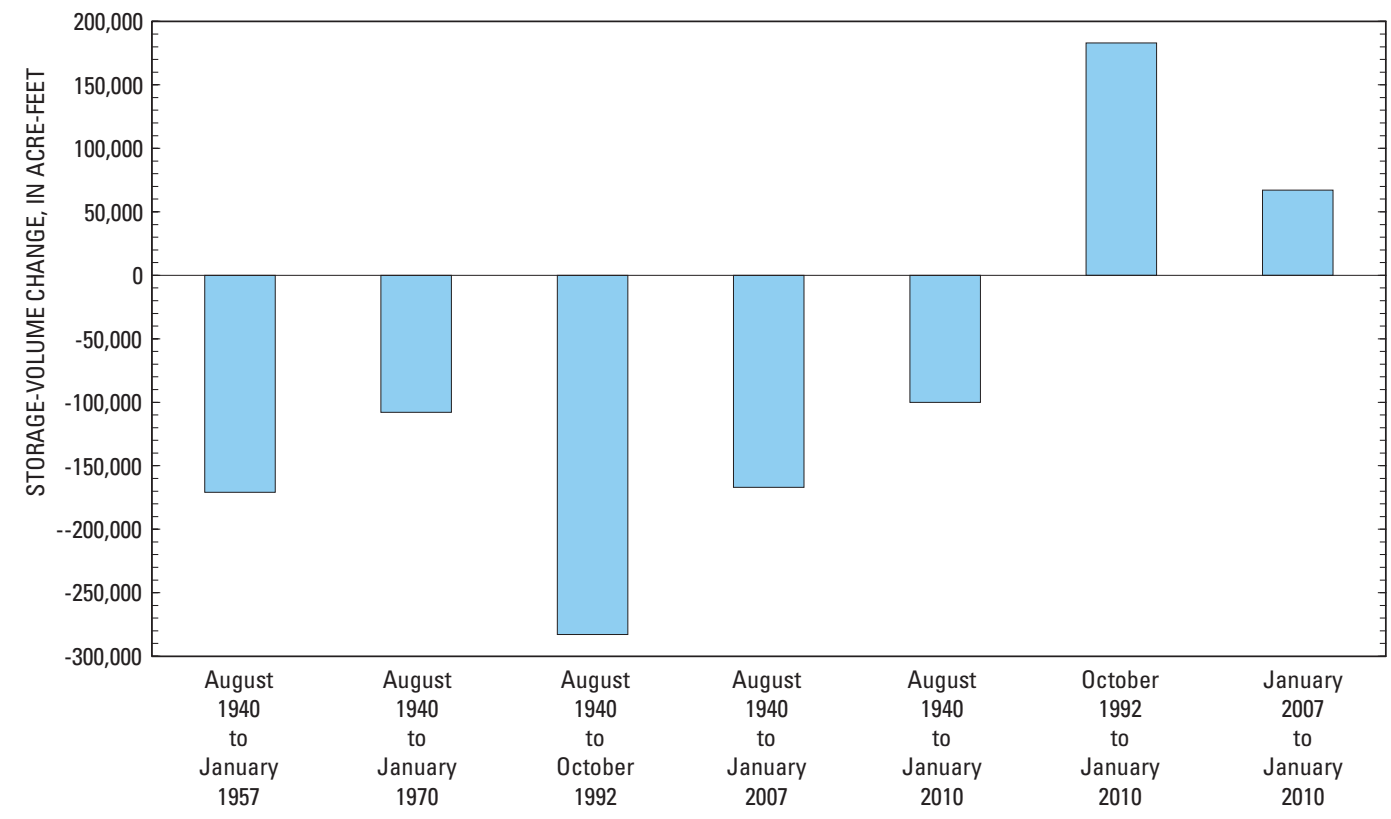

Figure 24. Comparison of storage-volume changes in the study area for selected periods. precipitation during 2007-09 was about 6 in/yr greater than the long-term average. The greater percentage storage-volume recovery during this period in the whole study area (about 40 percent) than in the central part of the study area (about 31 percent) may be in part because of decreased irrigation pumpage. Decreases in irrigation pumpage, which affect the whole study area, tend to be more closely linked to greaterthan-average precipitation than are the more managementdriven decreases in city pumpage, which occur almost exclusively in the central part of the study area. If artificial recharge increases and becomes similar in magnitude to the changes in city and irrigation pumpage, it would become a significant component of storage-volume change. During periods of lessthan-average precipitation, artificial recharge could become a more important component; however, reduced streamflow during periods of less-than-average precipitation may limit the ability of the city to artificially recharge the aquifer using water from the Little Arkansas River.

\section{Sustainable Yield}

The Equus Beds aquifer in the study area has experienced periods of substantial water-level decline and recovery. These changes in water levels and the resulting changes in storage volume have been a function of variations in natural recharge, evapotranspiration, well withdrawals, stream aquifer interactions, and movement of water within the aquifer into and out of the area. Artificial recharge quantities, although currently (2010) small compared to other water-budget components, are expected to increase in the future.

Sustainable yield is the development and use of groundwater in a manner that can be maintained for an indefinite time without causing unacceptable environmental, economic, or social consequences (Alley and others, 1999). An important characteristic of an aquifer's sustainable yield is the amount of groundwater that can be withdrawn from the aquifer on a longterm basis with limited adverse depletion of the groundwaterstorage reserve. Typically, a complex hydrologic computer model would be constructed to evaluate sustainable yield (for example, Myers and others, 1996; Burns and McDonnell, 2008).

Simple empirical approaches also can be used to estimate sustainable yield, provided that historical data describing groundwater withdrawals and aquifer storage exist. Such data are available for the Equus Beds aquifer in the study area and are shown in table 2. Table 2 shows annual estimates of the two primary components of groundwater withdrawals (irrigation and city pumpage) as well as a measure of aquifer storage, which is shown in the table as the departure from the 1940 storage volume.

The data in table 2 can be used to estimate sustainable yield with two different methods. In the first method, multiyear time periods (1989-95, 1999-2001, 2002-04, 2005-07) were identified during which the change in aquifer storage was minimal; the criterion for a minimal storage change was defined as a change in volume less than 5 percent of the annual pumpage. The average annual total pumpage values and precipitation departure from long-term average for the period of minimal net aquifer storage change are noted in table 3 .

The results in table 3 show that sustainable yields varied between 52,500 and 65,400 acre-ft/yr and averaged $56,600 \mathrm{acre}-\mathrm{ft} / \mathrm{yr}$ during periods of minimal storage-volume change. An interesting result is that the highest sustainable yield value is estimated for the driest period. This may indicate that water demands were higher during the driest years 


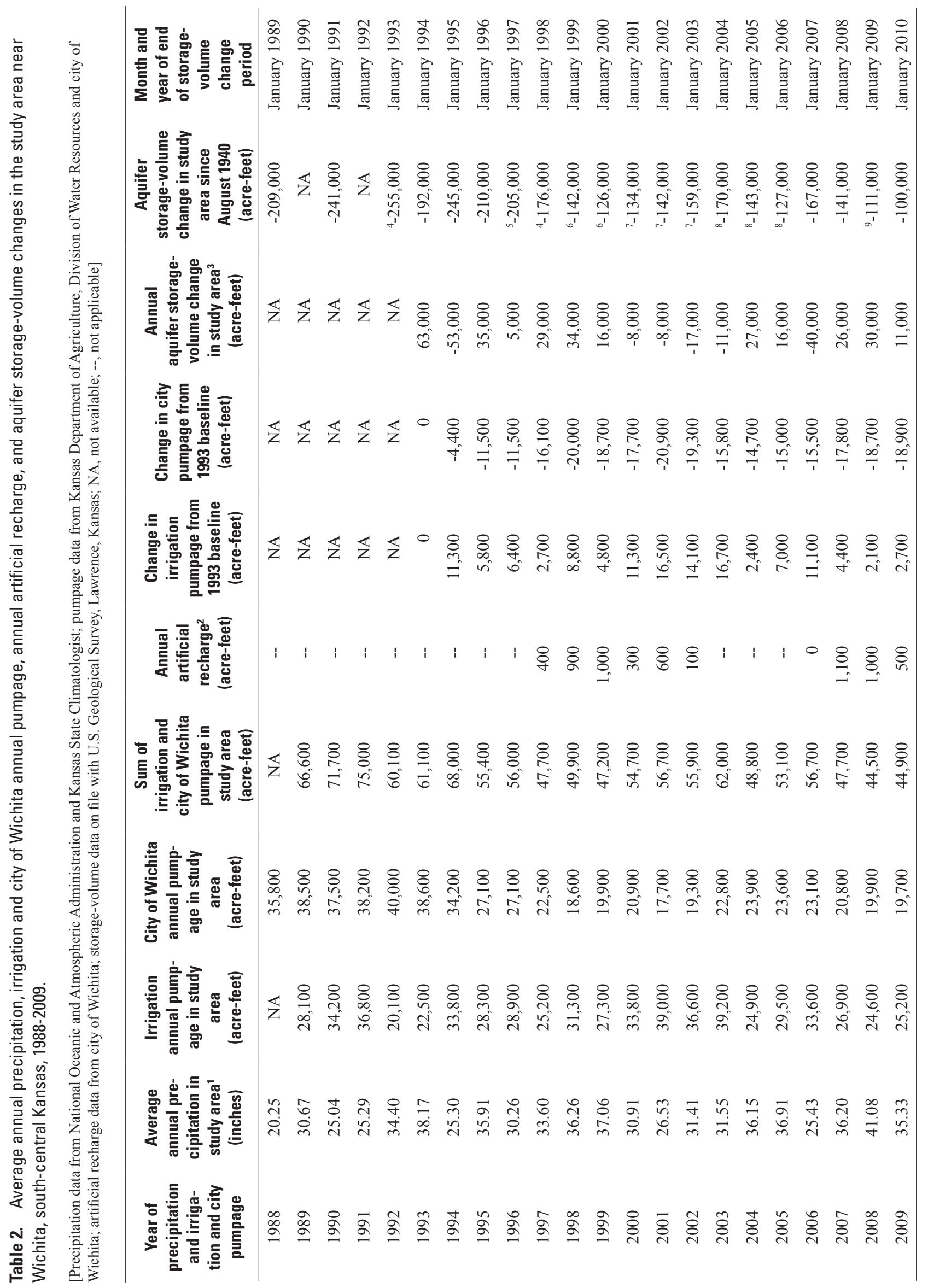



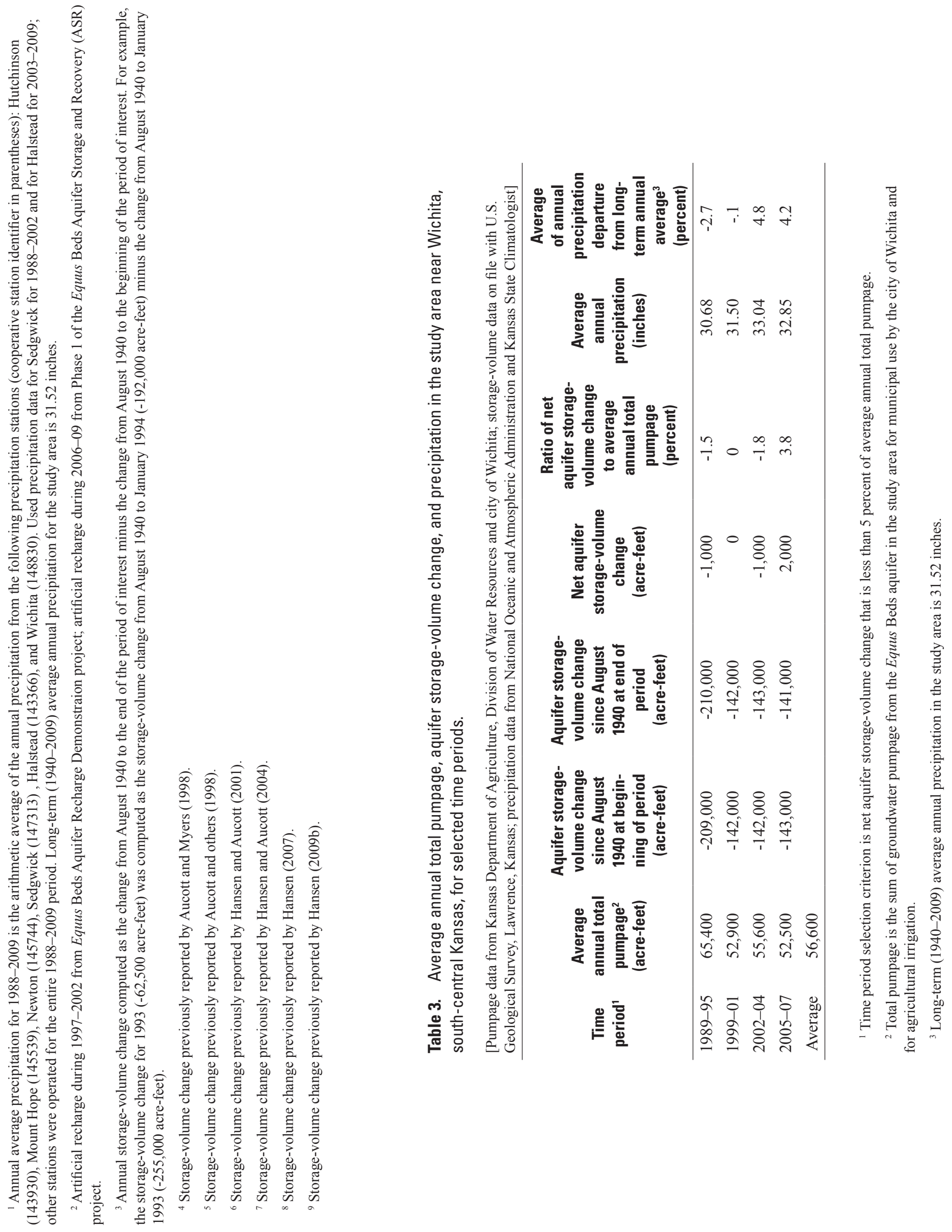
and that total withdrawals did not exceed the sustainable yield level.

In the second method of calculating sustainable yield, the annual total (irrigation plus city) pumpage and change in storage volume values for 1993 through 2009 from table 2 were plotted in relation to each other (fig. 25). Annual values of pumpage and storage-volume change were not available for the years before 1993. A linear regression of these data was estimated and a sustainable yield value of about 57,500 acre- $\mathrm{ft} / \mathrm{yr}$ was determined from the regression line as the total annual pumpage value (PUMP) where the annual change in storage ( $d S V$ ) was zero. The data spread in figure 25 is substantial as indicated by the coefficient of determination $\left(\mathrm{R}^{2}=0.26\right)$. Particularly notable are outliers corresponding to the largest flood (1993) and drought (2006) years and a major flood/drought transition year (1994). This indicates that lag times in the system make individual annual data points by themselves unreliable for a sustainable yield analysis. However, the similarity of the sustainable yield estimates from the two empirical methods (56,600 and 57,500 acre-ft/yr) provide confidence in the validity of the analysis.

In 2009, permitted groundwater-irrigation pumpage was about 45,600 acre-ft/yr and permitted municipal pumpage was about 31,400 acre-ft/yr for a permitted total of these two major uses in the study area of about 77,000 acre-ft/yr (Kansas Department of Agriculture, Division of Water Resources, unpub. data, April 2010). This amount of pumpage greatly exceeds the average amount of water available for withdrawal (about 57,000 acre-ft/yr) that would have minimal effect on storage. Effective water management-including additions to the water budget such as artificial recharge from Wichita's Equus Beds ASR project — can help produce the most water for beneficial use in a more sustainable manner.

\section{Summary}

A part of the Equus Beds aquifer in southwestern Harvey County and northwestern Sedgwick County was developed to supply water to residents of Wichita and for irrigation in south-central Kansas. Groundwater pumpage for city and agricultural use caused water levels to decline in a large part of the aquifer northwest of Wichita. In 1965, the city of Wichita began using water from Cheney Reservoir in addition to water from the Equus Beds aquifer to meet the city's increasing demand for water. Irrigation pumpage in the area increased substantially during the 1970 s and 1980 s and contributed to the water-level declines. Water-level declines reached their maximum to date in October 1992. Long-term water-level declines can be attributed to groundwater pumping; however, changes in precipitation (and thus recharge to the Equus Beds aquifer) also have affected groundwater levels. Proposals to artificially recharge the Equus Beds aquifer have been made since the 1950 s to meet future water-supply needs and to protect the aquifer from the intrusion of saltwater from natural and human-related sources to the south and west. In 2007, the city implemented Phase 1 of the Equus Beds Aquifer Storage and Recovery (ASR) project for large-scale artificial recharge of the aquifer.

Following record low water levels in October 1992, a period of water-level rises associated with generally greaterthan-average precipitation and decreased city pumpage from the study area that began in 1993 continued through January 2010. During January 2010, the direction of groundwater flow in the Equus Beds aquifer in the study area generally was from west to east, similar to prior to development of the aquifer in 1940. Water-level changes since August 1940 for the period January 2006 to January 2010 ranged from a decline of more than $30 \mathrm{ft}$ in July 2006 in the northern part of the study area

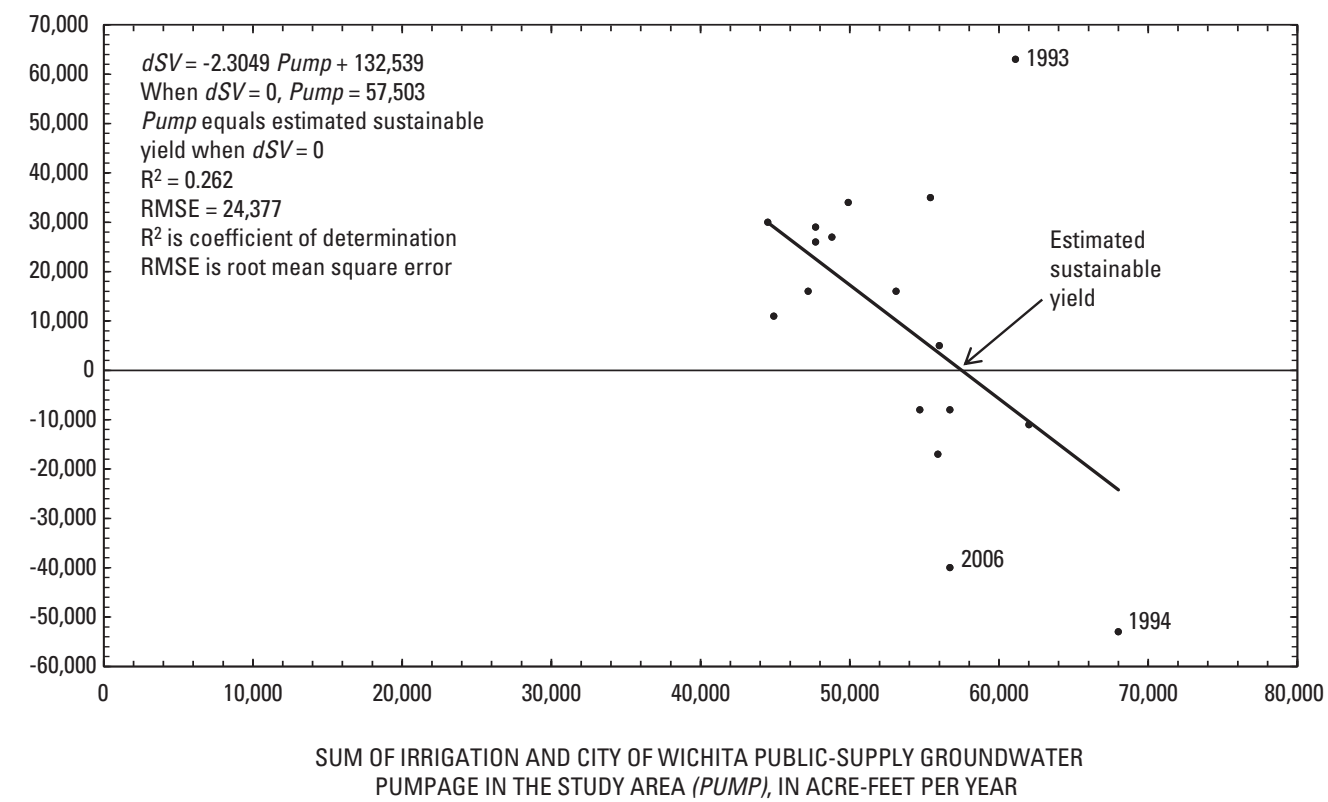

Figure 25. Statistical relation between storage volume and pumpage in the study area, 1993-2009. Outliers correspond to the largest flood (1993) and drought (2006) years and a major flood/drought transition year (1994). 
to a rise of more than $4 \mathrm{ft}$ in July 2007 near the Little Arkansas River. Almost all wells in the study area had cumulative water-level rises from October 1992 ( period of maximum storage loss) to January 2010 and from January 2007 (beginning of large-scale artificial recharge) to January 2010. The average cumulative water-level change in the study area from October 1992 to January 2010 was a rise of about $8.7 \mathrm{ft}$; from January 2007 to January 2010 the average cumulative waterlevel change was a rise of about $3.2 \mathrm{ft}$. Increased recharge from precipitation that was greater than the long-term average and decreased city pumpage contributed to water-level rises seen from October 1992 to January 2010 and from January 2007 to January 2010. City pumpage decreased from about 38,600 acre-ft in 1993 to about 19,700 acre-ft in 2009 or from about 60 to 32 percent of Wichita's usage. Annual precipitation during 1993-2009 averaged about 2 in/yr greater than the long-term average of 31.52 in.; precipitation during 2007-09 averaged about $6 \mathrm{in} / \mathrm{yr}$ greater than the long-term average. Irrigation pumpage increased from about 22,500 acre-ft in 1993 to about 25,200 acre-ft in 2009 and was as much or more during most of the intervening years; thus it did not contribute to the water level rises seen from October 1992 to January 2010. Irrigation pumpage varied considerably from year to year; reduced irrigation pumpage could contribute to water-level rises in some years. Artificial recharge of about 5,900 acre-ft also contributed to the water level rises, but principally in the vicinity of the recharge sites.

The storage-volume change in the study area from October 1992 to January 2010 represents a recovery of about 183,000 acre-ft or about 65 percent of storage previously lost between August 1940 and October 1992. The storage-volume change in the central part of the study area from October 1992 to January 2010 represents a recovery of about 101,400 acre$\mathrm{ft}$ or about 64 percent of storage previously between August 1940 and October 1992. These are the largest post-October 1992 storage-volume recoveries to date in the study area and central part of the study area. Artificial recharge and the decrease in city pumpage contributed to the recovery of storage volume, but artificial recharge's contribution was more than an order of magnitude smaller. Irrigation pumpage, because it was an increase did not contribute to the recovery of storage volume from October 1992 to January 2010. Recharge from excess precipitation contributed to the recovery of storage volume in this period because precipitation averaged about $2 \mathrm{in} / \mathrm{yr}$ more than the annual long-term average of $31.52 \mathrm{in.}$

Storage-volume recoveries for the period January 2007 to January 2010 were about 40 and 31 percent of the storage volume previously lost between August 1940 and January 2007 in the study area and central part of the study area, respectively. Decreases in irrigation and city pumpage and artificial recharge of about 2,600 acre-ft contributed to the recovery of storage volume during this period. Recharge from precipitation also contributed to the recovery because precipitation during 2007-09 was about 6 in/yr greater than the long-term average. The larger percentage recovery of storage volume from January 2007 to January 2010 in the whole study area (40 percent) as compared to central part of the study area (31 percent) may be in part because decreases in irrigation pumpage, which affect the whole study area, tend to be more closely linked to greater-than-average precipitation than are the more management-driven decreases in city pumpage, which occur almost exclusively in the central part of the study area. During periods of less-than-average precipitation, artificial recharge could become a more important component of storage-volume change; however, reduced streamflow during these periods may limit the ability of the city to artificially recharge the aquifer using water from the Little Arkansas River.

The sustainable yield of the Equus Beds aquifer in the study area was estimated using two methods. In the first method, the sustainable yield was estimated as approximately equivalent to the average annual sum of irrigation and city pumpage for four periods when the change in storage volume was less than 5 percent of annual pumpage from the study area. Sustainable yield from this method ranged from 52,500 acre-ft/yr to 65,400 acre-ft/yr and averaged 56,600 acre-ft/yr. The second method estimated a similar sustainable yield of 57,500 acre-ft/yr using a linear regression of the annual sum of irrigation and city pumpage with the annual change in storage volume. The sum of permitted annual irrigation (about 45,600 acre-ft/yr) and city (about 31,400 acre-ft/ yr) pumpage of about 77,000 acre-ft/yr greatly exceeds the average estimated sustainable yield of about 57,000 acre-ft/ yr. Effective water management, including additions to the water budget such as those from the Equus Beds ASR project, can help produce the most water for beneficial use in a more sustainable manner.

\section{References Cited}

Albert, C.D., and Stramel, G.J., 1966, Fluvial sediment in the Little Arkansas River Basin, Kansas: U.S. Geological Survey Water-Supply Paper 1798-B, 30 p.

Alley, W.M., Reilly, T.E., and Franke, O.L., 1999, Sustainability of ground-water resources: U.S. Geological Survey Circular 1186, 79 p.

Aucott, W.R., and Myers, N.C., 1998, Changes in groundwater levels and storage in the Wichita well field area, south-central Kansas, 1940-98: U.S. Geological Survey Water-Resources Investigations Report 98-4141, 20 p.

Aucott, W.R., Myers, N.C., and Dague, B.J., 1998, Status of ground-water levels and storage in the Wichita well field area, south-central Kansas, 1997: U.S. Geological Survey Water-Resources Investigations Report 98-4095, 15 p.

Bayne, C.K., 1956, Geology and ground-water resources of Reno County, Kansas: Kansas Geological Survey Bulletin 120, 130 p. 
Bohling G.C., and Wilson, B.B., 2004, Statistical and geostatistical analysis of the Kansas High Plains water-table elevations, 2004 measurement campaign: Kansas Geological Survey Open-File Report 2004-57, 39 p.

Bohling G.C., and Wilson, B.B., 2005, Statistical and geostatistical analysis of the Kansas High Plains water-table elevations, 2005 measurement campaign: Kansas Geological Survey Open-File Report 2005-6, 43 p.

Bohling G.C., and Wilson, B.B., 2006, Statistical and geostatistical analysis of the Kansas High Plains water-table elevations, 2006 measurement campaign: Kansas Geological Survey Open-File Report 2006-20, 40 p.

Bohling G.C., and Wilson, B.B., 2007, Statistical and geostatistical analysis of the Kansas High Plains water-table elevations, 2007 measurement campaign: Kansas Geological Survey Open-File Report 2007-32, 47 p

Buddemeier, R.W., Stotler, R., Butler, J.J., Jr., Jin, W., Beeler, K., Reboulet, E., Macfarlane, P.A., Kreitzer, S., Whittemore, D.O., Bohling, G., and Wilson, B.B., 2010, High Plains aquifer calibration monitoring well program: Third year progress report: Kansas Geological Survey Open-File Report 2010-3, 36 p.

Burns and McDonnell, 2008, Aquifer storage and recovery project 2007 accounting report: Kansas City, Missouri, Burns and McDonnell Engineering Company, Inc., prepared for the city of Wichita, Kansas, various pagination.

Equus Beds Groundwater Management District No. 2, 1995, Equus Beds Groundwater Management District No. 2 management program: Halstead, Kansas, 99 p.

Hansen, C.V., 2007, Status of ground-water levels and storage volume in the Equus Beds aquifer near Wichita, Kansas, January 2003-January 2006: U.S. Geological Survey Scientific Investigations Report 2006-5321, 34 p.

Hansen, C.V., 2009a, Status of ground-water levels and storage volume in the Equus Beds aquifer near Wichita, Kansas, July 2008: U.S. Geological Survey Scientific Investigations Map 3075, 1 sheet.

Hansen, C.V., 2009b, Status of groundwater levels and storage volume in the Equus Beds aquifer near Wichita, Kansas, January 2009: U.S. Geological Survey Scientific Investigations Map 3087, 1 sheet.

Hansen, C.V., and Aucott, W.R., 2001, Status of ground-water levels and storage volume in the Wichita well field area, south-central Kansas, 1998-2000: U.S. Geological Survey Water-Resources Investigations Report 00-4267, 27 p.
Hansen, C.V., and Aucott, W.R., 2004, Status of groundwater levels and storage volume in the Equus Beds aquifer near Wichita, Kansas, January 2000-January 2003: U.S. Geological Survey Water-Resources Investigations Report 03-4298, 36 p.

Hufford, D.B., [1983?], The ayes have it! Wichita Water Department - a history 1882-1982: Topeka, Kansas, Jostens, various pagination, accessed May 27, 2010 at http: //www.wichita.gov/CityOffices/WaterAndSewer/ WWDHistoryBook/.

Juracek, K.E., and Hansen, C.V., 1995, Digital maps of the extent, base, and 1991 potentiometric surface of the High Plains aquifer in Kansas: U.S. Geological Survey Open-File Report 95-758, digital data set.

Kansas Geological Survey, 2002, WIZARD water well levels database: Kansas Geological Survey, accessed November 7, 2006, at http://www.kgs.ku.edu/Magellan/WaterLevels/ index.html.

Laflen, D.R., and Miller, R.D., 2003, 2003 annual water level raw data report for Kansas: Kansas Geological Survey Open-File Report 2003-001, 13 p.

Laflen, D.R., and Miller, R.D., 2004, 2004 annual water level raw data report for Kansas: Kansas Geological Survey Open-File Report 2004-6, 13 p.

Laflen, D.R., and Miller, R.D., 2005, 2005 annual water level data collection report for Kansas: Kansas Geological Survey Open-File Report 2005-55, accessed November 8, 2006, at http://www.kgs.ku.edu/Magellan/WaterLevels/CD/Reports/ OFR05_55/rep00.htm.

Lane, C.W., and Miller, D.E., 1965a, Geohydrology of Sedgwick County, Kansas: Kansas Geological Survey Bulletin $176,100 \mathrm{p}$.

Lane, C.W., and Miller, D.E., 1965b, Logs of wells and test holes in Sedgwick County, Kansas: Kansas Geological Survey Special Distribution Publication 22, 175 p.

Leonard, R.B., and Kleinschmidt, M.K., 1976, Saline water in the Little Arkansas River Basin area, south-central Kansas: Kansas Geological Survey Chemical Quality Series 3, 24 p.

McGuire, V.L., 2001, Water-level changes in the High Plains aquifer, 1980 to 1999: U.S. Geological Survey Fact Sheet 029-01, 2 p.

McGuire, V.L., 2003, Water-level changes in the High Plains aquifer, predevelopment to 2001, 1999-2000, and 20002001: U.S. Geological Survey Fact Sheet 078-03, 4 p.

McGuire, V.L., 2004a, Water-level changes in the High Plains aquifer, predevelopment to 2002, 1980-2002, and 20012002: U.S. Geological Survey Fact Sheet 2004-3026, 6 p. 
McGuire, V.L., 2004b, Water-level changes in the High Plains aquifer, predevelopment to 2003 and 2002 to 2003: U.S. Geological Survey Fact Sheet 2004-3097, 6 p.

McGuire, V.L., 2007, Water-level changes in the High Plains aquifer, predevelopment to 2005 and 2003 to 2005: U.S. Geological Survey Scientific Investigations Report 20065324,7 p.

McGuire, V.L., 2009, Water-level changes in the High Plains aquifer, predevelopment to 2007, 2005-6, and 2006-07: U.S. Geological Survey Scientific Investigations Report 2009-5019, 9 p.

McGuire, V.L., and Fischer, B.C., 1999, Water-level changes, 1980 to 1997, and saturated thickness, 1996-97, in the High Plains aquifer: U.S. Geological Survey Fact Sheet 124-99, $4 \mathrm{p}$.

McGuire, V.L., Johnson, M.R., Schieffer, R.L., Stanton, J.S., Sebree, S.K., and Verstraeten, I.M., 2003, Water in storage and approaches to ground-water management, High Plains aquifer, 2000: U.S. Geological Circular 1243, 51 p.

McGuire, V.L., and Sharpe, J.B., 1997, Water-level changes in the High Plains aquifer-Predevelopment to 1995: U.S. Geological Survey Water-Resources Investigations Report 97-4081, 2 sheets, scale 1:2,500,000.

Mitchell, J.E., Woods, John, McClain, T.J., and Buddemeier, R.W., 1993, January 1992 Kansas water levels and data related to water-level changes: Kansas Geological Survey Technical Series 3, $130 \mathrm{p}$.

Mitchell, J.E., Woods, J.J., McClain, T.J., and Buddemeier, R.W., 1994, January 1993 Kansas water levels and data related to water-level changes: Kansas Geological Survey Technical Series 4, $114 \mathrm{p}$.

Myers, N.C., Hargadine, G.D., and Gillespie, J.D., 1996, Hydrologic and chemical interaction of the Arkansas River and the Equus Beds aquifer between Hutchinson and Wichita, south-central Kansas: U.S. Geological Survey Water-Resources Investigations Report 95-4191, 100 p.

National Oceanic and Atmospheric Administration, 1998, Climatological data, annual summary, Kansas, 1997: Asheville, North Carolina, v. 111, no. 13, 35 p.

National Oceanic and Atmospheric Administration, 1999, Climatological data, annual summary, Kansas, 1998: Asheville, North Carolina, v. 112, no. 13, 31 p.

National Oceanic and Atmospheric Administration, 2000, Climatological data, annual summary, Kansas, 1999: Asheville, North Carolina, v. 113, no. 13, 35 p.

National Oceanic and Atmospheric Administration, 2001, Climatological data, annual summary, Kansas, 2000: Asheville, North Carolina, v. 114, no. 13, 33 p.
National Oceanic and Atmospheric Administration, 2002a, Climatological data, annual summary, Kansas, 2001: Asheville, North Carolina, v. 115, no. 13, 36 p.

National Oceanic and Atmospheric Administration, 2002b, Monthly station normals of temperature, precipitation, and heating and cooling degree days, 1971-2000, Kansas: Asheville, North Carolina, Climatography of the United States No. $81,37 \mathrm{p}$.

National Oceanic and Atmospheric Administration, 2003, Climatological data, annual summary, Kansas, 2002: Asheville, North Carolina, v. 116, no. 13, 32 p.

National Oceanic and Atmospheric Administration, 2004, Climatological data, annual summary, Kansas, 2003: Asheville, North Carolina, v. 117, no. 13, 32 p.

National Oceanic and Atmospheric Administration, 2005a, Climatological data, annual summary, Kansas, 2004: Asheville, North Carolina, v. 118, no. 13, 32 p.

National Oceanic and Atmospheric Administration, 2005b, Daily precipitation data for United States cooperative and National Weather Service sites: Asheville, North Carolina, National Climatic Data Center, accessed February 21, 2006, at http://www.ncdc.noaa.gov/oa/climate/stationlocator.html.

National Oceanic and Atmospheric Administration, 2007, Climatological data, annual summary, Kansas, 2006: Asheville, North Carolina, v. 120, no. 13, 41 p.

National Oceanic and Atmospheric Administration, 2008, Climatological data, annual summary, Kansas, 2007: Asheville, North Carolina, v. 121, no. 13, 41 p.

National Oceanic and Atmospheric Administration, 2009, Climatological data, annual summary, Kansas, 2008: Asheville, North Carolina, v. 122, no. 13, 41 p.

National Oceanic and Atmospheric Administration, 2010, Daily precipitation data for United States cooperative and National Weather Service sites: Asheville, North Carolina, National Climatic Data Center, accessed January 28, 2010, at http://www.ncdc.noaa.gov/oa/climate/stationlocator.html.

Olea, R.A., and Davis, J.C., 2003, Geostatistical analysis and mapping of water-table elevations in the High Plains aquifer of Kansas after the 2003 monitoring season: Kansas Geological Survey, Open-File Report 2003-13, 39 p.

Ross, H.C., Myers, N.C., and Aucott, W.R., 1997, Increased use of Cheney Reservoir for Wichita area water supply benefits Equus Beds aquifer: U.S. Geological Survey Fact Sheet 196-97, 2 p.

Schoewe, W.H., 1949, The geography of Kansas, part 2Physical geography: Transactions of the Kansas Academy of Science, v. 52, no. 3, p. 261-333. 
Spinazola, J.M., Gillespie, J.B., and Hart, R.J., 1985, Groundwater flow and solute transport in the Equus beds area, south-central Kansas: U.S. Geological Survey WaterResources Investigations Report 85-4336, 68 p.

Stallman, R.W., 1971, Aquifer-test design, observation and data analysis: U.S. Geological Survey Techniques of WaterResources Investigations, book 3, chap. B-1, p. 14-16.

Stramel, G.J., 1956, Progress report on the ground-water hydrology of the Equus beds area, Kansas: Kansas Geological Survey Bulletin 119, part 1, 59 p.

Stramel, G.J., 1967, Progress report on the ground-water hydrology of the Equus beds area, Kansas 1966: Kansas Geological Survey Bulletin 187, part 2, 27 p.

Stullken, L.E., Watts, K.R., and Lindgren, R.J., 1985, Geohydrology of the High Plains aquifer, western Kansas: U.S. Geological Survey Water-Resources Investigations Report 85-4198, 86 p.

Thiessen, A.H., 1911, Precipitation averages for large areas: Monthly Weather Review, v. 39, p. 1,082-1,084.

U.S. Geological Survey, 2006, Highlights of Equus Beds ground-water recharge project: Information available on the Web, accessed November 7, 2006, at http://ks.water.usgs. gov/Kansas/studies/equus/equus_hilites.html.

Warren, D.R., Blain, G.T., Shorney, F.L., and Klein, L.J., 1995, IRP - A case study from Kansas: Journal of the American Water Works Association, June 1995, p. 57-71.

Wichita Water Department, [1959?], 1958 annual report: Wichita, Kansas, city of Wichita, 8 p.

Wichita Water Utilities, [2007?], Wichita area future water supply: A model program for other municipalities: Wichita, Kansas, accessed March 24, 2009, at http://www.wichita. gov/CityOffices/WaterAndSewer/ProductionAndPumping/ FutureWaterSupply.htm.

Wichita Water Utilities, [2008?], Equus Beds Aquifer Storage and Recovery (ASR) project fact sheet and timeline: Wichita, Kansas, accessed May 27, 2010, at http://www. wichita.gov/NR/rdonlyres/C3F1FBD7-5652-4D31-B35A8EB6D4FF4BAD/0/ASRFactSheet_timeline.pdf.

Williams, C.C., and Lohman, S.W., 1949, Geology and ground-water resources of a part of south-central Kansas, with special reference to the Wichita municipal water supply: Kansas Geological Survey Bulletin 79, 455 p.

Woods, J.J., Mitchell, J.E., and Buddemeier, R.W., 1994, January 1994 Kansas water levels and data related to water-level changes: Kansas Geological Survey Technical Series 5, $106 \mathrm{p}$.
Woods, J.J., and Schloss, J.A., 1996, January 1996 Kansas water levels and data related to water-level changes: Kansas Geological Survey Technical Series 9, 124 p.

Woods, J.J., Schloss, J.A., and Buddemeier, R.W., 1995, January 1995 Kansas water levels and data related to water-level changes: Kansas Geological Survey Technical Series 8, $138 \mathrm{p}$.

Woods, J.J., Schloss, J.A., and Macfarlane, P.A, 1997, January 1997 Kansas water levels and data related to water-level changes: Kansas Geological Survey Technical Series 11, $90 \mathrm{p}$.

Woods, J.J., Schloss, J.A., and Macfarlane, P.A., 1998, January 1998 Kansas water levels and data related to water-level changes: Kansas Geological Survey Technical Series 12, $92 \mathrm{p}$.

Woods, J.J., Schloss, J.A., and Macfarlane, P.A., 1999, January 1999 Kansas water-level measurements: Kansas Geological Survey Technical Series 14, 89 p.

Woods, J.J., Schloss, J.A., and Macfarlane, P.A., 2000, January 2000 Kansas water levels and data related to water-level changes: Kansas Geological Survey Technical Series 15, 89 p.

Woods, J.J., and Sophocleous, M.A., 2002, January 2001 Kansas water levels and data related to water-level changes: Kansas Geological Survey Technical Series 17, 95 p.

Woods, J.J., and Sophocleous, M.A., 2004, January 2002 Kansas water levels and data related to water-level changes: Kansas Geological Survey Technical Series 19, 92 p.

Young, D.P., Buddemeier, R.W., Butler, J.J., Jr., Jin, W., Whittemore, D.O., Reboulet, E., and Wilson, B.B., 2008, High Plains aquifer calibration monitoring well program: Year 2 progress report: Kansas Geological Survey Open-File Report 2008-29, 54 p.

Ziegler, A.C., Christensen, V.G., and Ross, H.C., 1999, Baseline water quality and preliminary effects of artificial recharge on ground water, south-central Kansas, 1995-98: U.S. Geological Survey Water-Resources Investigations Report 99-4250, 74 p.

Ziegler, A.C., Hansen, C.V., and Finn, D.A., 2010, Water quality in the Equus Beds aquifer and the Little Arkansas River before implementation of large-scale artificial recharge, south-central Kansas, 1995-2005: U.S. Geological Survey Scientific Investigations Report 2010-5023, 64 p. 
Appendix 
Table A1. Streamflow-gaging stations and observation wells in the Equus Beds aquifer, south-central Kansas.

[USGS, U.S. Geological Survey]

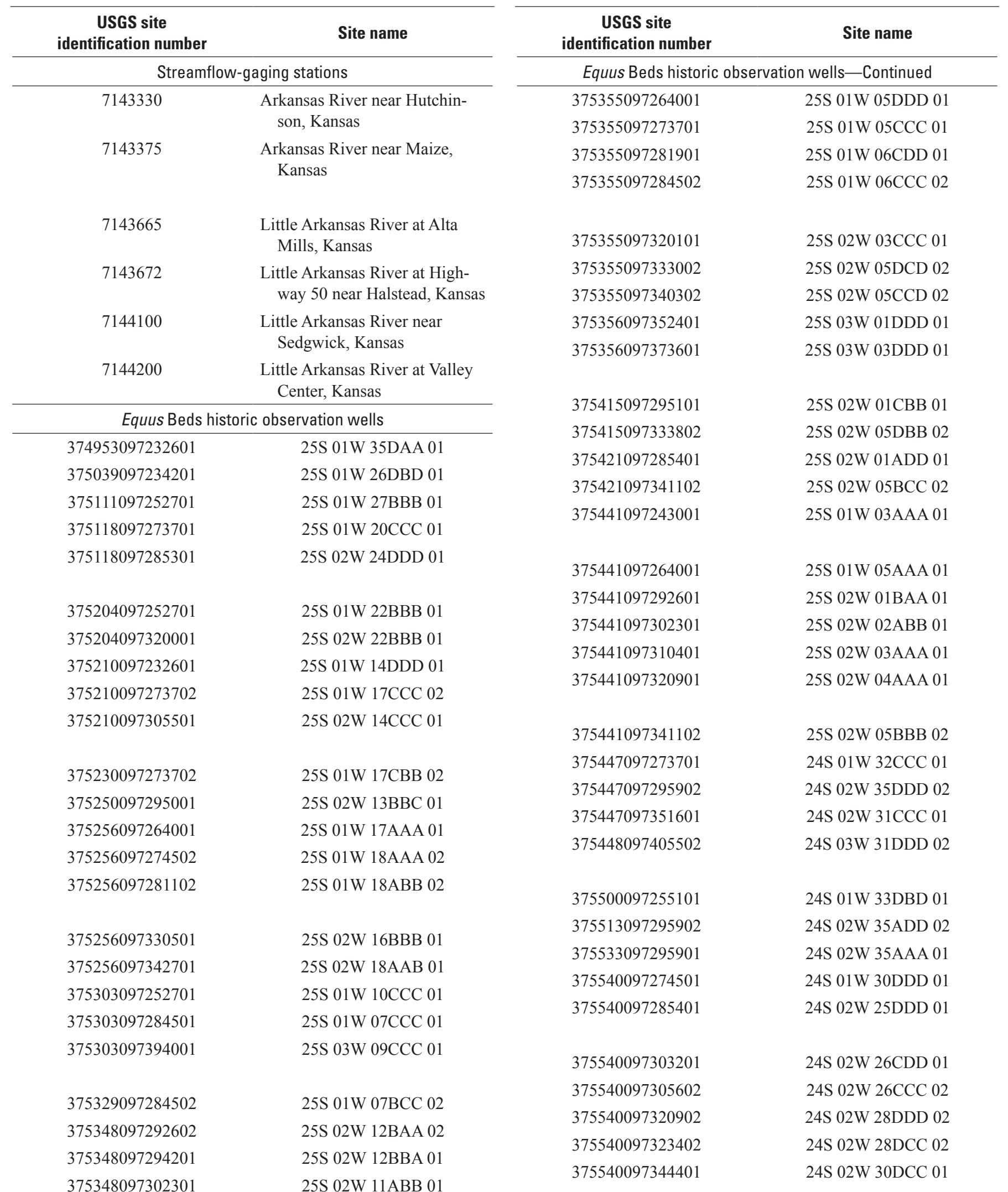

375348097305602

25S 02W 11BBB 02 
Table A1. Streamflow-gaging stations and observation wells in the Equus Beds aquifer, south-central Kansas.-Continued

[USGS, U.S. Geological Survey]

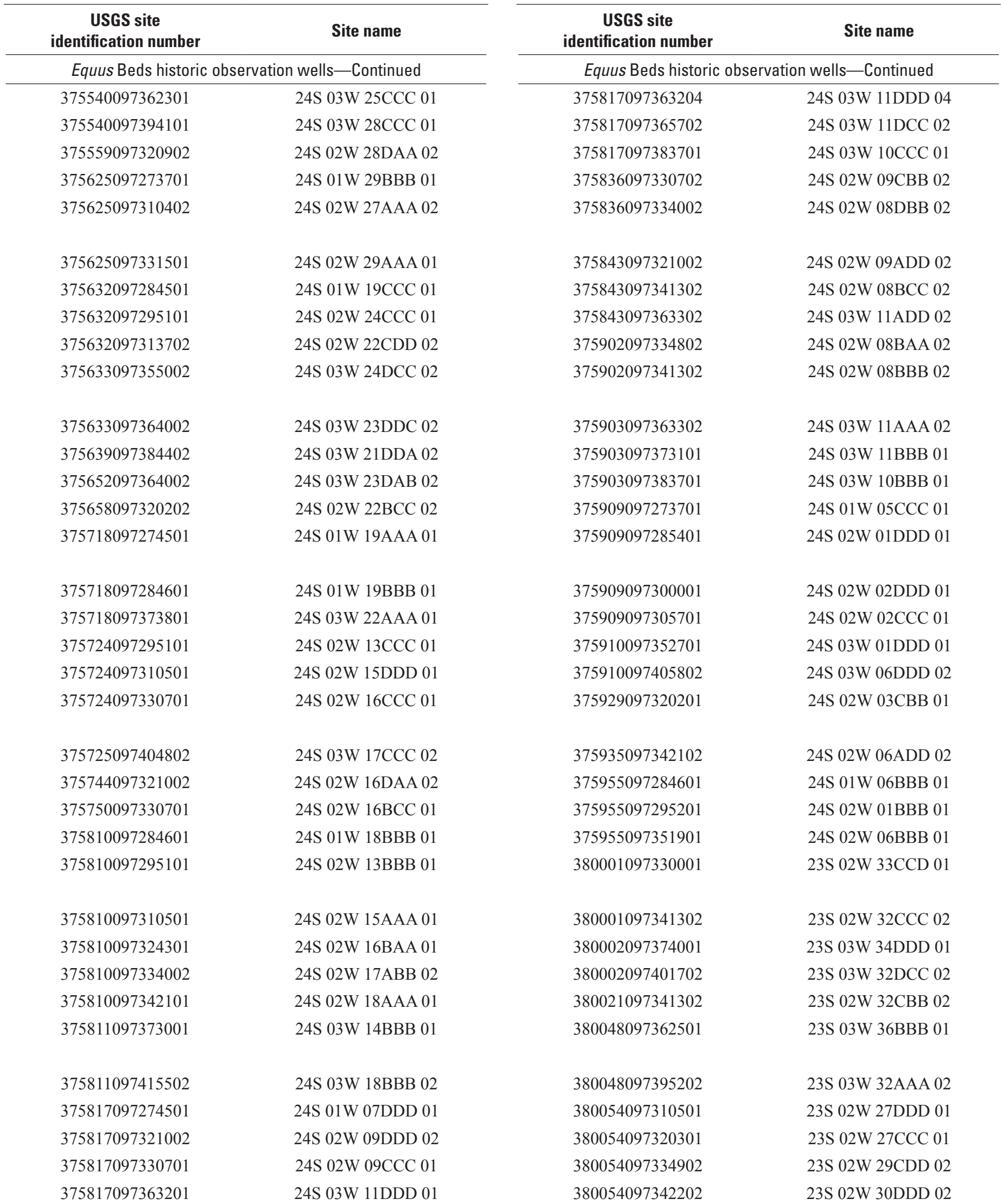


Table A1. Streamflow-gaging stations and observation wells in the Equus Beds aquifer, south-central Kansas.-Continued [USGS, U.S. Geological Survey]

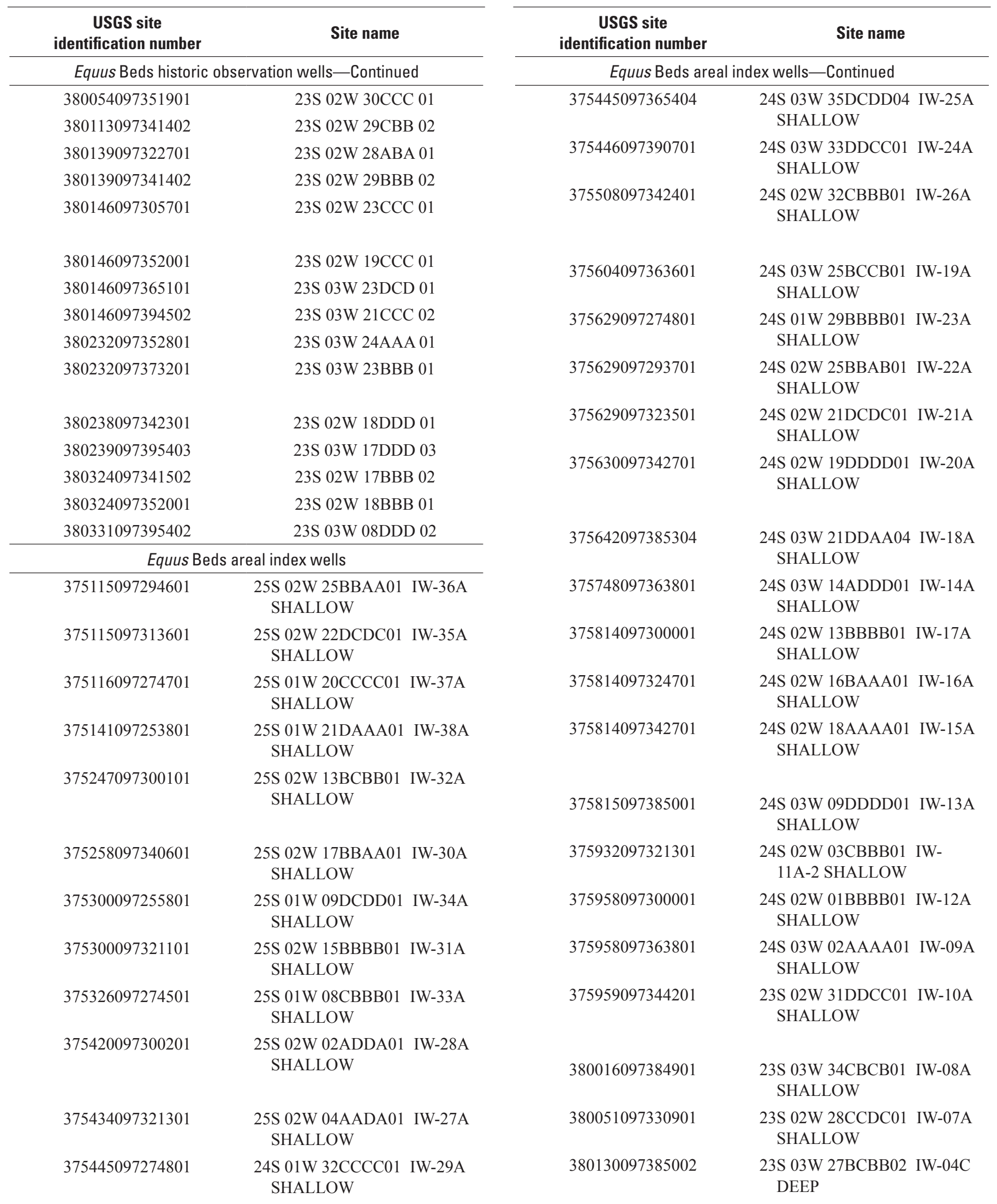


Table A1. Streamflow-gaging stations and observation wells in the Equus Beds aquifer, south-central Kansas.Continued

[USGS, U.S. Geological Survey]

\begin{tabular}{|c|c|}
\hline $\begin{array}{c}\text { USGS site } \\
\text { identification number }\end{array}$ & Site name \\
\hline \multicolumn{2}{|c|}{ Equus Beds areal index wells-Continued } \\
\hline 380143097344201 & $\begin{array}{l}\text { 23S 02W 30AAAB01 IW-06A } \\
\text { SHALLOW }\end{array}$ \\
\hline 380144097371101 & $\begin{array}{l}\text { 23S 03W 23DCCC01 IW-05A } \\
\text { SHALLOW }\end{array}$ \\
\hline 380328097342501 & $\begin{array}{l}\text { 23S 02W 17BBBB01 IW-03A } \\
\text { SHALLOW }\end{array}$ \\
\hline 380329097363702 & $\begin{array}{l}\text { 23S 03W 12CCCC02 IW-02C } \\
\text { DEEP }\end{array}$ \\
\hline 380421097385002 & $\begin{array}{l}\text { 23S 03W 03CCCC02 IW-01C } \\
\text { DEEP }\end{array}$ \\
\hline
\end{tabular}

Table A2. Precipitation stations in and near the study area, south-central Kansas.

[--, not applicable $]$

\begin{tabular}{|c|c|c|c|c|}
\hline Precipitation station name & Period of data used & County & $\begin{array}{c}\text { Cooperative } \\
\text { station } \\
\text { identifier }\end{array}$ & $\begin{array}{l}\text { Weather Bureau- } \\
\text { Army-Navy (WBAN) } \\
\text { station identifier }\end{array}$ \\
\hline Wichita WB Airport & 1948 to 1954 & Sedgwick & 148828 & 13998 \\
\hline $\begin{array}{l}\text { Wichita Municipal Airport and } \\
\text { Wichita Mid-Continent Airport }\end{array}$ & 1954 to 2010 & Sedgwick & 148830 & 03928 \\
\hline Sedgwick and Sedgwick $1 \mathrm{~W}$ & 1938 to 2003 & Harvey & 147313 & -- \\
\hline Halstead $3 \mathrm{SW}$ & 2003 to 2010 & Harvey & 143366 & -- \\
\hline Newton $3 \mathrm{E}$ & 1938 to August 1951 & Harvey & 145744 & -- \\
\hline Newton $2 \mathrm{SW}$ & August 1951 to 2010 & Harvey & 145744 & -- \\
\hline Mount Hope & 1938 to 2010 & Sedgwick & 145539 & -- \\
\hline Hutchinson Municipal Airport & 1948 to 1959 & Reno & 143926 & 13986 \\
\hline Hutchinson $10 \mathrm{SW}$ & 1959 to 2010 & Reno & 143930 & -- \\
\hline
\end{tabular}


Publishing support provided by:

Rolla and Lafayette Publishing Service Centers

For additional information concerning this publication, contact: Director, USGS Kansas Water Science Center

4821 Quail Crest Place

Lawrence, KS 66049

(785) 842-9909

Or visit the Kansas Water Science Center Web site at: http://ks.water.usgs.gov 



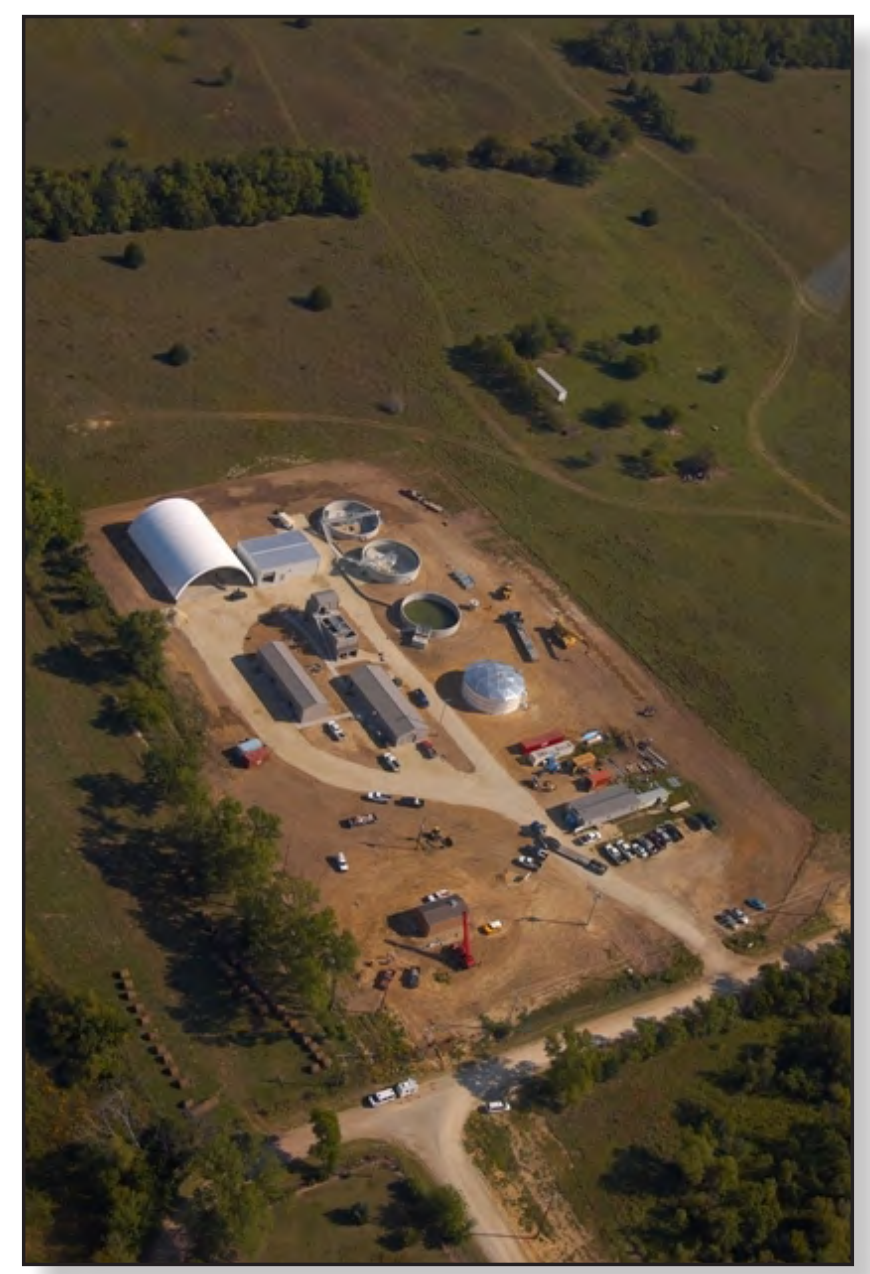

